Nevada

Environmental

Restoration

Project

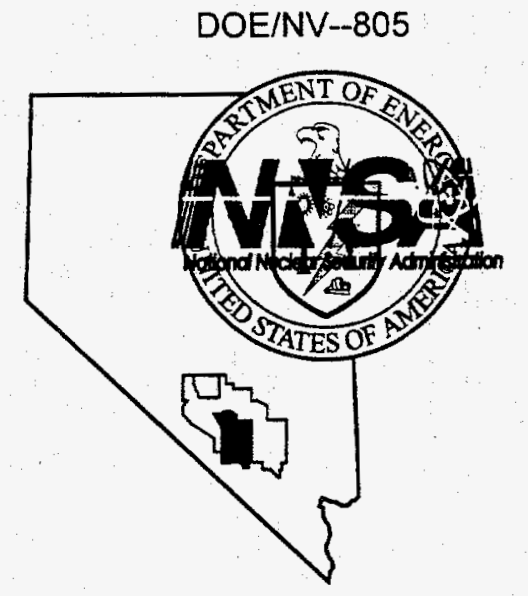

\title{
Annual Report
}

RCRA Post-Closure Monitoring

and Inspections for CAU 91:

Area 3 U-3fi Injection Well,

Nevada Test Site, Nevada

For the Period

October 2000 - October 2001

Controlled Copy No.:

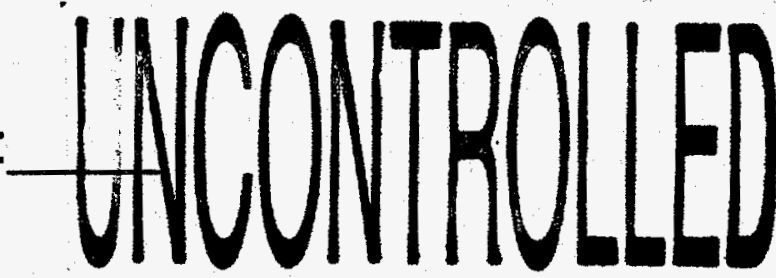

Revision: 0

February 2002

Environmental Restoration

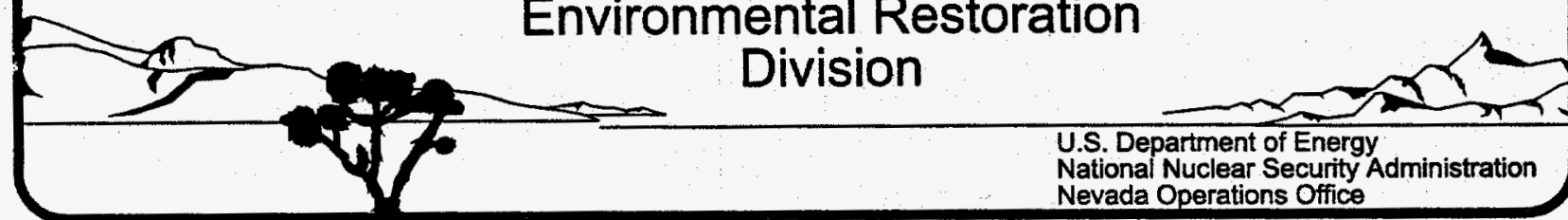




\section{DISCLAIMER STATEMENT}

This report was prepared as an account of work sponsored by an agency of the U.S. Government. Neither the U.S. Government nor any agency thereof, nor any of their employees, makes any warranty or representation, express or implied, or assumes any legal liability or responsibility for the accuracy, completeness, or usefulness of any information, apparatus, product, or process disclosed, or represents that its use would not infringe privately owned rights. Reference herein to any specific commercial product, process, or service by trade name, trademark, manufacturer, or otherwise does not necessarily constitute or imply its endorsement, recommendation, or favoring by the U.S. Government or any agency thereof. The views and opinions of authors expressed herein do not necessarily state or reflect those of the U.S. Government or any agency thereof.

\section{AVAILABILITY STATEMENT}

Available for sale to the public from-

U.S. Department of Commerce

National Technical Information Service

5285 Port Royal Road

Springfield, VA 22161

Phone: 800.553 .6847

Fax: 703.605.6900

Email: orders@ntis.fedworld.gov

Online ordering: http://www.ntis.gov/ordering.htm

Available electronically at http://www.doe.gov.bridge

Available for a processing fee to U.S. Department of Energy and its contractors, in paper, fromU.S. Department of Energy

Office of Scientific and Technical Information

P.O. Box 62

Oak Ridge, TN 37831-0062

Phone: 865.576 .8401

Fax: 865.576 .5728

Email: reports@adonis.osti.gov 


\author{
ANNUAL REPORT \\ RCRA POST-CLOSURE MONITORING \\ AND INSPECTIONS FOR \\ CORRECTIVE ACTION UNIT 91: \\ AREA 3 U-3fi INJECTION WELL, \\ NEVADA TEST SITE, NEVADA \\ FOR THE PERIOD \\ OCTOBER 2000 - OCTOBER 2001
}

\author{
Prepared for: \\ National Nuclear Security Administration \\ Nevada Operations Office \\ Under Contract No. DE-AC08-96NV11718
}

Controlled Copy No.:

Revision: 0

February 2002 


\title{
ANNUAL REPORT RCRA POST-CLOSURE MONITORING AND INSPECTIONS FOR CORRECTIVE ACTION UNIT 91: AREA 3 U-3fi INJECTION WELL, NEVADA TEST SITE, NEVADA
}

\author{
FOR THE PERIOD \\ OCTOBER 2000 - OCTOBER 2001
}
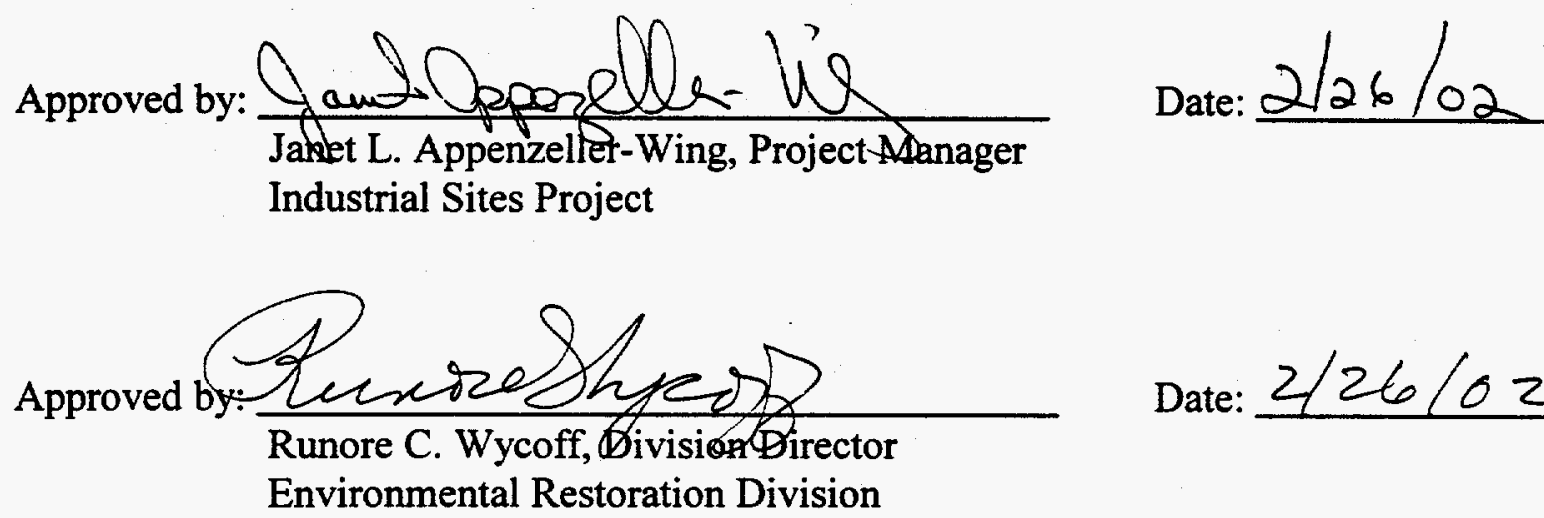

Date: $2 / 26 / 02$ 


\section{TABLE OF CONTENTS}

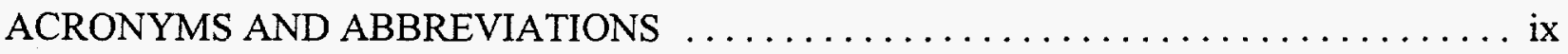

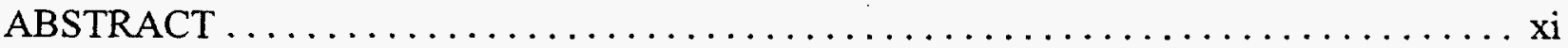

PROJECT SUMMARY $\ldots \ldots \ldots \ldots \ldots \ldots \ldots \ldots \ldots \ldots \ldots \ldots \ldots \ldots \ldots \ldots \ldots, \ldots \ldots \ldots$

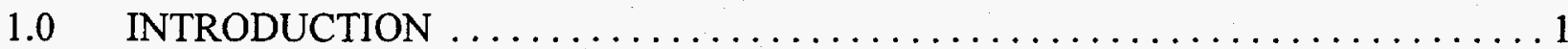

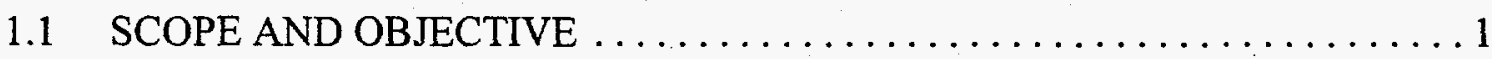

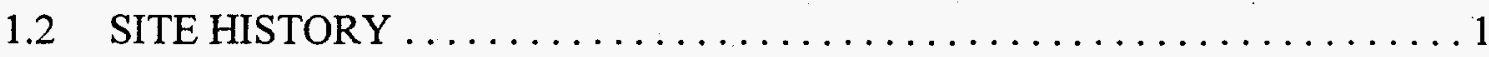

1.3 SITE GEOLOGY AND HYDROLOGY $\ldots \ldots \ldots \ldots \ldots \ldots \ldots \ldots \ldots$

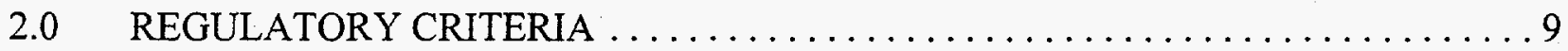

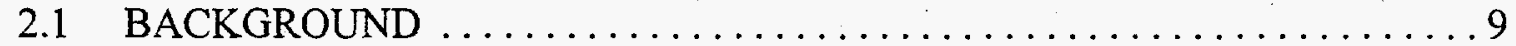

2.2 SITE INSPECTION COMPLIANCE CRITERIA $\ldots \ldots \ldots \ldots \ldots \ldots \ldots$

2.3 SOIL MOISTURE MONITORING COMPLIANCE CRITERIA $\ldots \ldots \ldots 11$

3.0 SITE INSPECTIONS AND ANNUAL SUBSIDENCE SURVEY $\ldots \ldots \ldots \ldots \ldots 13$

3.1 INTRODUCTION .................................. 13

3.2 FINDINGS FROM THE SITE INSPECTIONS $\ldots \ldots \ldots \ldots \ldots \ldots \ldots \ldots$

3.3 ANNUAL SUBSIDENCE SURVEY $\ldots \ldots \ldots \ldots \ldots \ldots \ldots \ldots \ldots$

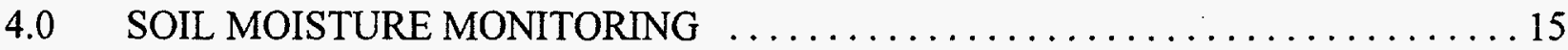

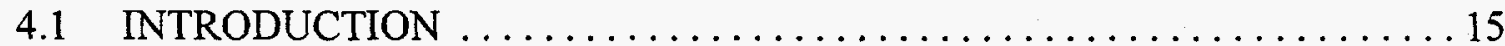

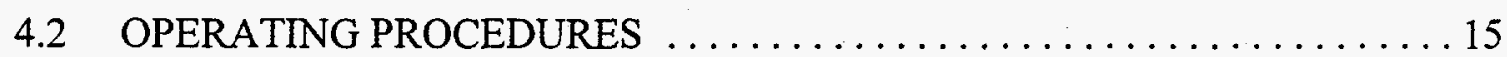

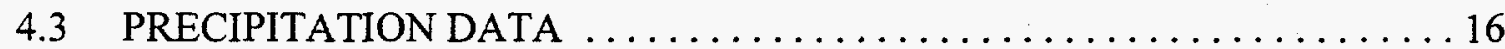

4.4 SOIL MOISTURE MONITORING RESULTS $\ldots \ldots \ldots \ldots \ldots \ldots \ldots \ldots$

4.4.1 Data Presentation .............................. 16

4.4.2 Discussion of Analytical Data Trends .................. 19

4.4.2.1 January 2001 - First Quarter ..................... 19

4.4.2.2 April 2001 - Second Quarter ..................... 19

4.4.2.3 July 2001 - Third Quarter ....................20

4.4.2.4 October 2001 - Fourth Quarter.................... 20

5.0 SUMMARY, CONCLUSIONS, AND RECOMMENDATIONS $\ldots \ldots \ldots \ldots \ldots \ldots 27$

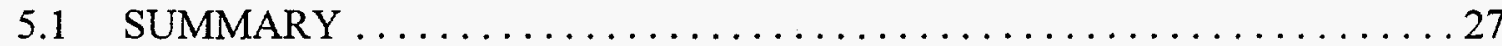

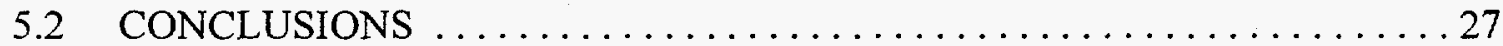

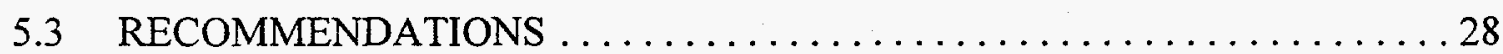

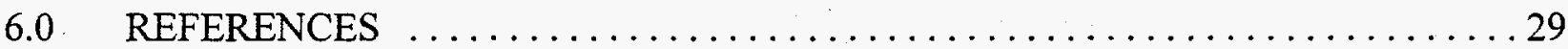




\section{TABLE OF CONTENTS (Continued)}

\section{APPENDICES}

APPENDIX A: POST-CLOSURE CARE INSPECTION CHECKLISTS

APPENDIX B: SUBSIDENCE SURVEY PLAT

APPENDIX C: PRECIPITATION RECORDS

DISTRIBUTION LIST

\section{FIGURES}

FIGURE PS-1 - ER3-3 CUMULATIVE RESIDUAL NEUTRON COUNTS ........ PS-5

FIGURE PS-2 - ER3-3 BASELINE DIFFERENCE FIRST QUARTER ............ PS-6

FIGURE PS-3 - ER3-3 BASELINE DIFFERENCE SECOND QUARTER . . . . . . . . PS-7

FIGURE PS-4 - ER3-3 BASELINE DIFFERENCE THIRD QUARTER . . . . . . . . P PS-8

FIGURE PS-5 - ER3-3 BASELINE DIFFERENCE FOURTH QUARTER $\ldots \ldots \ldots \ldots$ PS-9

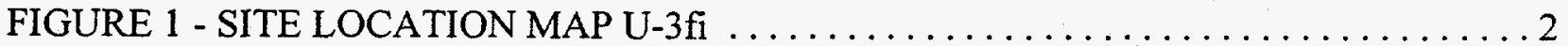

FIGURE 2 - CROSS SECTION OF THE U-3fi WASTE DISPOSAL UNIT $\ldots \ldots \ldots \ldots . .3$

FIGURE 3 - MONTHLY PRECIPITATION $\ldots \ldots \ldots \ldots \ldots \ldots \ldots \ldots \ldots \ldots \ldots \ldots \ldots \ldots \ldots \ldots$

FIGURE 4 - ER3-3 CUMULATIVE RESIDUAL NEUTRON COUNTS $\ldots \ldots \ldots \ldots \ldots \ldots 21$

FIGURE 5 - ER3-3 BASELINE DIFFERENCE FIRST QUARTER $\ldots \ldots \ldots \ldots \ldots \ldots 22$

FIGURE 6 - ER3-3 BASELINE DIFFERENCE SECOND QUARTER $\ldots \ldots \ldots \ldots \ldots 23$

FIGURE 7 - ER3-3 BASELINE DIFFERENCE THIRD QUARTER $\ldots \ldots \ldots \ldots \ldots \ldots 24$

FIGURE 8 - ER3-3 BASELINE DIFFERENCE FOURTH QUARTER $\ldots \ldots \ldots \ldots \ldots \ldots 25$ 


\section{TABLE OF CONTENTS (Continued)}

\section{TABLES}

TABLE 1 - CHRONOLOGY OF THE AREA 3 U-3fi WASTE DISPOSAL UNIT $\ldots \ldots \ldots 6$

TABLE 2 - SUBSIDENCE MONUMENT U-3fi COORDINATES AND ELEVATIONS ‥ . 14

TABLE 3 - PRECIPITATION DATA FOR THE BUSTER JANGLE Y, METEOROLOGICAL STATION BJY, AREA 3, NTS ............... 17 


\section{THIS PAGE INTENTIONALLY LEFT BLANK}




\section{ACRONYMS AND ABBREVIATIONS}

$\begin{array}{ll}\text { bgs } & \text { below ground surface } \\ \text { BN } & \text { Bechtel Nevada } \\ \text { BJY } & \text { Buster Jangle Y } \\ \mathrm{cm} & \text { centimeter(s) } \\ \text { DOE } & \text { U.S. Department of Energy } \\ \text { DOENV } & \text { U.S. Department of Energy, Nevada Operations Office } \\ \mathrm{ft} & \text { foot (feet) } \\ \text { in } & \text { inch(es) } \\ \text { km } & \text { kilometer(s) } \\ \text { LANL } & \text { Los Alamos National Laboratory } \\ \text { m } & \text { meter(s) } \\ \text { mi } & \text { mile(s) } \\ \text { NDEP } & \text { Nevada Division of Environmental Protection } \\ \text { NTS } & \text { Nevada Test Site } \\ \text { RCRA } & \text { Resource Conservation and Recovery Act } \\ \text { REECo } & \text { Reynolds Electrical and Engineering Co., Inc. }\end{array}$


Post Closure Monitoring Report - CAU No. 91 Section: ACC \& ABB

Revision: 0

Date: January 10. 2002 


\section{ABSTRACT}

This annual Neutron Soil Moisture Monitoring report provides an analysis and summary for site inspections, meteorological information, and neutron soil moisture monitoring data obtained at the U-3fi Injection Well during the October 2000 to October 2001 period. The U-3fi Injection Well is located in Area 3 of the Nevada Test Site (NTS), Nye County, Nevada.

Inspections of the Area 3 U-3fi Injection Well are conducted to determine and document the physical condition of the concrete pad, facilities, and any unusual conditions that could impact the proper operation of the waste disposal unit closure.

The objective of the neutron-logging program is to monitor the soil moisture conditions along the 128-meter (m) (420-feet [ft]) ER3-3 monitoring well and detect changes that may be indicative of moisture movement in the regulated interval extending between 73 to $82 \mathrm{~m}$ ( $240 \mathrm{to} 270 \mathrm{ft}$ ) or to detect changes that may be indicative of subsidence within the disposal unit itself.

Physical inspections of the closure were completed in March and September 2001 and indicated that the site is in good condition with no significant findings noted.

The subsidence survey for the October 2000 to October 2001 monitoring period was completed in July 2001 with a monument elevation of $1,230.833 \mathrm{~m}(4,038.166 \mathrm{ft})$ which indicated a subsidence of $-0.427 \mathrm{~cm}(-0.014 \mathrm{ft})$ relative to the baseline survey of September 1996, and an slight decrease in elevation of $0.061 \mathrm{~cm}(0.002 \mathrm{ft})$ compared to the previous year, July 2000 . While the survey results show a negative subsidence after the baseline survey, the magnitude of these changes is so small as to be at the survey instrument resolution level and it is not clear if they represent subsidence or measurement error. There is no clear evidence for any subsidence of the monument.

Soil moisture monitoring results indicate dry stable conditions for all quarterly monitoring periods. The Residual Raw Neutron Counts remain below the compliance Action Level of 200 counts within the regulated interval of 73 to $82 \mathrm{~m}$ ( 240 to $270 \mathrm{ft}$ ) for the period from October 2000 through October 2001. 
Post Closure Monitoring Report - CAU No. 91 Section: ABSTRACT

Revision: 0

Date: January 10. 2002

THIS PAGE INTENTIONALLY LEFT BLANK 


\section{PROJECT SUMMARY}

\section{INTRODUCTION}

This annual Neutron Soil Moisture Monitoring report provides an analysis and summary for site inspections, meteorological information, and neutron soil moisture monitoring data obtained at the U-3fi Injection Well during the October 2000 to October 2001 period. The U-3fi Injection Well is located in Area 3 of the Nevada Test Site (NTS), Nye County, Nevada.

Inspections of the Area 3 U-3fi Injection Well are conducted to determine and document the physical condition of the concrete pad, facilities, and any unusual conditions that could impact the proper operation of the waste disposal unit closure.

The objective of the neutron logging is to monitor the soil moisture conditions along the 128-meter (m) (420-feet [ft]) ER3-3 monitoring well and detect changes that may be indicative of moisture movement in the regulated interval extending between 73 to $82 \mathrm{~m}$ ( 240 to $270 \mathrm{ft}$ ).

\section{REGULATORY CRITERIA}

Soil moisture compliance monitoring is done in compliance with the May 31, 1997, Class One Modification of the Nevada Division of Environmental Protection Permit for a Hazardous Waste Management Facility, Permit Number NEV HW009. The Class One Permit Modification incorporated the criteria presented in the October 1996 letter (U.S. Department of Energy, Nevada Operations Office [DOE/NV], 1996) requesting changes in the Resource Conservation and Recovery Act Industrial Sites Environmental Restoration Post-Closure Plan, Area 3 U-3fi Waste Unit, DOE/NV, 1995c).

The ER3-3 post-closure monitoring criteria requires notification to the Nevada Division of Environmental Protection (NDEP) if the residual raw neutron counts (Observed Raw Counts minus Baseline Raw Counts) exceeds the 200-count Action Level in the regulated interval extending between 73 to $82 \mathrm{~m}$ ( 240 to $270 \mathrm{ft}$ ) for two or more consecutive quarterly monitoring periods.

The ER3-3 post-closure monitoring criteria also requires notification to the NDEP if settling in the U-3fi borehole has occurred on a scale large enough to cause shearing of the lower portion of the ER3-3 monitoring well.

A directional survey is to be run in the ER3-3 access casing every five years to determine if subsidence is occurring the U-3fi emplacement borehole. The first survey was conducted in July 2000. 


\section{RESULTS OF INSPECTIONS AND THE MONITORING PROGRAM}

\section{Inspections}

Site inspections are performed or conducted every six months to identify any significant changes to the unit requiring action. No significant concerns were noted.

\section{Subsidence Survey}

The subsidence survey for the October 2000 to October 2001 monitoring period was completed in July 2001 with a monument elevation of $1,230.833 \mathrm{~m}(4,038.166 \mathrm{ft})$ which indicated a subsidence of $-0.427 \mathrm{~cm}(-0.014 \mathrm{ft})$ relative to the baseline survey of September 1996, and a slight decrease in elevation of $0.061 \mathrm{~cm}(0.002 \mathrm{ft})$ compared to the previous year, July 2000 . While the survey results show a negative subsidence after the baseline survey, the magnitude of these changes is so small as to be at the survey instrument resolution level and it is not clear if they represent subsidence or measurement error. There is no clear evidence of any subsidence of the monument.

\section{Precipitation}

Precipitation data were collected from the National Weather Service Nuclear Support Office's CLINET Station Buster Jangle Y located at $37^{\circ} 03^{\prime} 46^{\prime \prime} \mathrm{N}, 116^{\circ} 03^{\prime} 09^{\prime \prime} \mathrm{W}$, in Area 3 of the NTS. This station is located approximately 4.8 kilometers ( 3 miles) northwest of Well ER3-3.

The average annual precipitation over the period 1960 to 2001 at the BJY Station is 16.36 centimeters $(\mathrm{cm})$ (6.44 inches [in.]). The annual precipitation (January 2001 through December 2001$)$ is $15.49 \mathrm{~cm}(6.10 \mathrm{in}$.). The yearly precipitation for the current monitoring period, October 2000 through October 2001 , is $15.72 \mathrm{~cm}$ (6.19 in.).

\section{Soil Moisture Monitoring}

The Cumulative Residual Neutron Counts graph (Figure PS-1) tracks changes over time from baseline conditions relative to the regulatory level of concern. The residual raw counts are calculated by subtracting the raw neutron count of each monitoring period from the first-year average neutron count (baseline). While the data are collected on a $0.3-\mathrm{m}(1-\mathrm{ft})$ interval, the Cumulative Residual Neutron Count graph only presents the residual count every $1.5 \mathrm{~m}(5 \mathrm{ft})$ in the regulated interval between 73.2 to $82.3 \mathrm{~m} \mathrm{(} 240$ to $270 \mathrm{ft})$. This interval corresponds to the point closest to the bottom of the U-3fi emplacement casing. The residual values are plotted as 
residual raw counts vs date for each $1.5-\mathrm{m}$ (5-ft) depth. The level of regulatory concern is indicated as a heavy line at the 200-count Action Level. Values exceeding this limit for two consecutive monitoring periods require notifying the NDEP as specified in the revised PostClosure Plan.

The next four graphs (Figures PS-2 through PS-5) show the baseline difference for successive quarterly monitoring periods along the entire length of a neutron access tube relative to baseline conditions. These are calculated by subtracting the baseline (first-year average) raw neutron count from the current raw neutron count on a depth basis. The result of this subtraction is referred to as the residual raw count. The residual raw count is plotted with the actual raw neutron counts of both the current and baseline data vs depth from the top of the casing. A positive residual neutron count indicates conditions at that depth and point in time that are wetter than baseline conditions, while negative values indicate dryer conditions.

The Baseline Difference graphs provide detailed information on the overall performance of the entire unit.

The Cumulative Residual graph focuses only on cumulative trends relative to the regulatory level of concern and is used to determine regulatory compliance.

\section{SUMMARY}

- Inspections of the cover were performed or calculated to identify any significant changes to the unit requiring action. No significant concerns were noted.

- The subsidence survey for the October 2000 to October 2001 monitoring period was completed in July 2001 with a monument elevation of $1,230.833 \mathrm{~m}$ $(4,038.166 \mathrm{ft})$ which indicated a subsidence of $-0.427 \mathrm{~cm}(-0.014 \mathrm{ft})$ relative to the baseline survey of September 1996, and an slight decrease in elevation of $0.061 \mathrm{~cm}(0.002 \mathrm{ft})$ compared to the previous year, July 2000 . While the survey results show a negative subsidence after the baseline survey, the magnitude of these changes is so small as to be at the survey instrument resolution level and it is not clear if they represent subsidence or measurement error. There is no clear evidence for any subsidence of the monument.

- Visual inspections of the concrete cover indicate no evidence of subsidence.

- The ER3-3 neutron moisture data obtained in 2001 are below the Action Level of 200 residual raw counts within the regulated interval. 


\section{CONCLUSIONS}

- No significant concerns were observed during the site inspections over the period October 2000 through October 2001.

- There is no subsidence of the ER3-3 monument.

- The moisture content of the regulated interval between 73.2 to $82.3 \mathrm{~m} \mathrm{(240}$ to $270 \mathrm{ft}$ ) remains dry, stable, and shows no signs of subsidence.

- $\quad$ Both the baseline difference and cumulative residual data indicate dry stable conditions for all quarterly monitoring periods. The residual raw neutron counts remain below the compliance Action Level of 200 counts within the regulated interval for period from October 2000 through October 2001.

- The closure is in compliance and performing as designed.

\section{RECOMMENDATIONS}

Although not within a compliance interval or of regulatory concern, the drying trend observed in the bentonite seal and sloughed soils beneath the cement wellhead protection plug will continue to be monitored to determine if the void area is increasing. 
Post Closure Monitoring Repot - CAL No. 91 Section: PROJECT SUMMARY

\section{ER3-3 Soil Moisture Monitoring \\ Cumulative Residual Neutron Counts \\ July 1995 through October 2001}
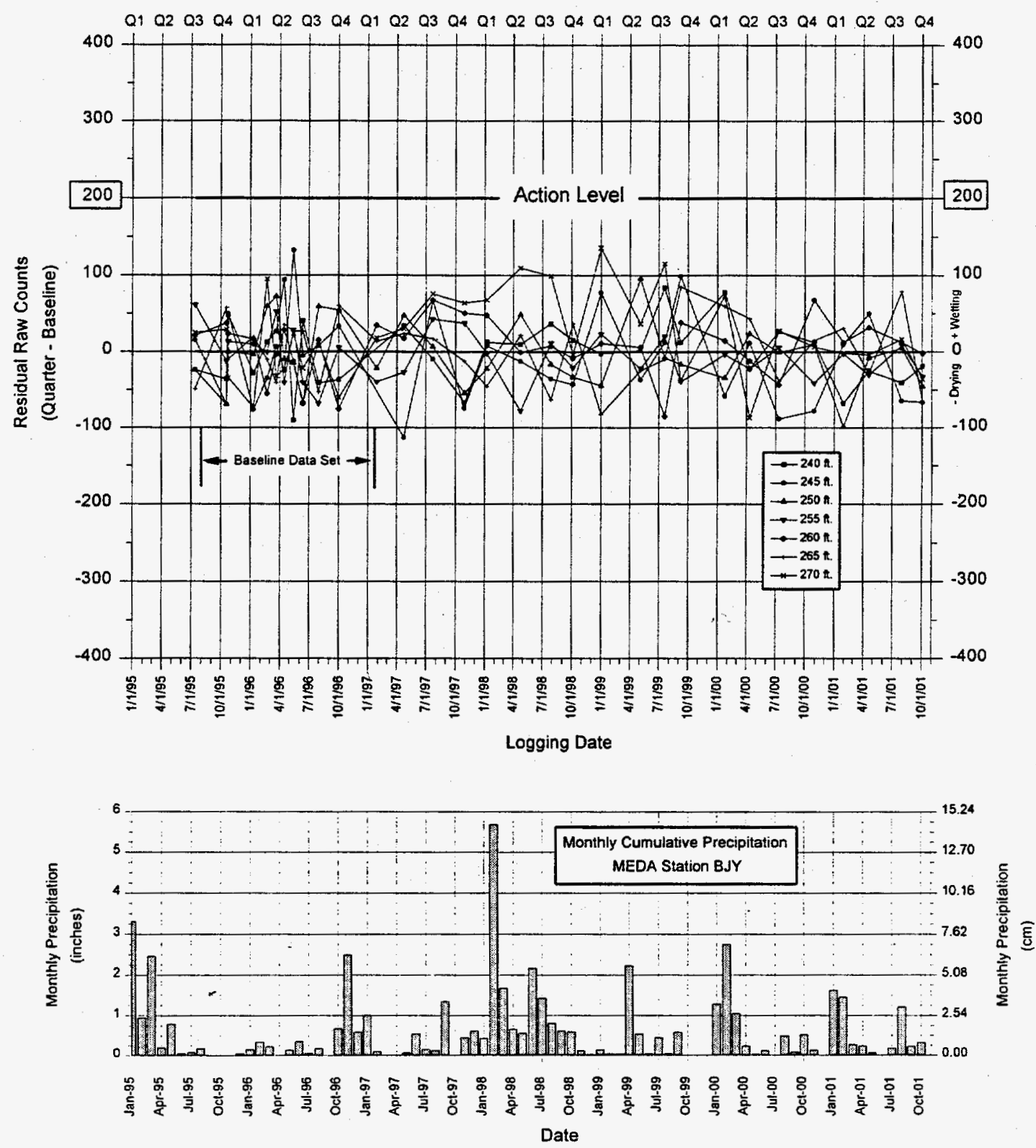

FIGURE PS-1. ER3-3 CUMULATIVE RESIDUAL NEUTRON COUNTS 
Post Closure Monitorini Report - CAU No. 91 Section: PROJECT SUMMARY

\section{ER3-3 Soil Moisture Monitoring}

Baseline Difference

January $20011^{\text {st }}$ Quarter

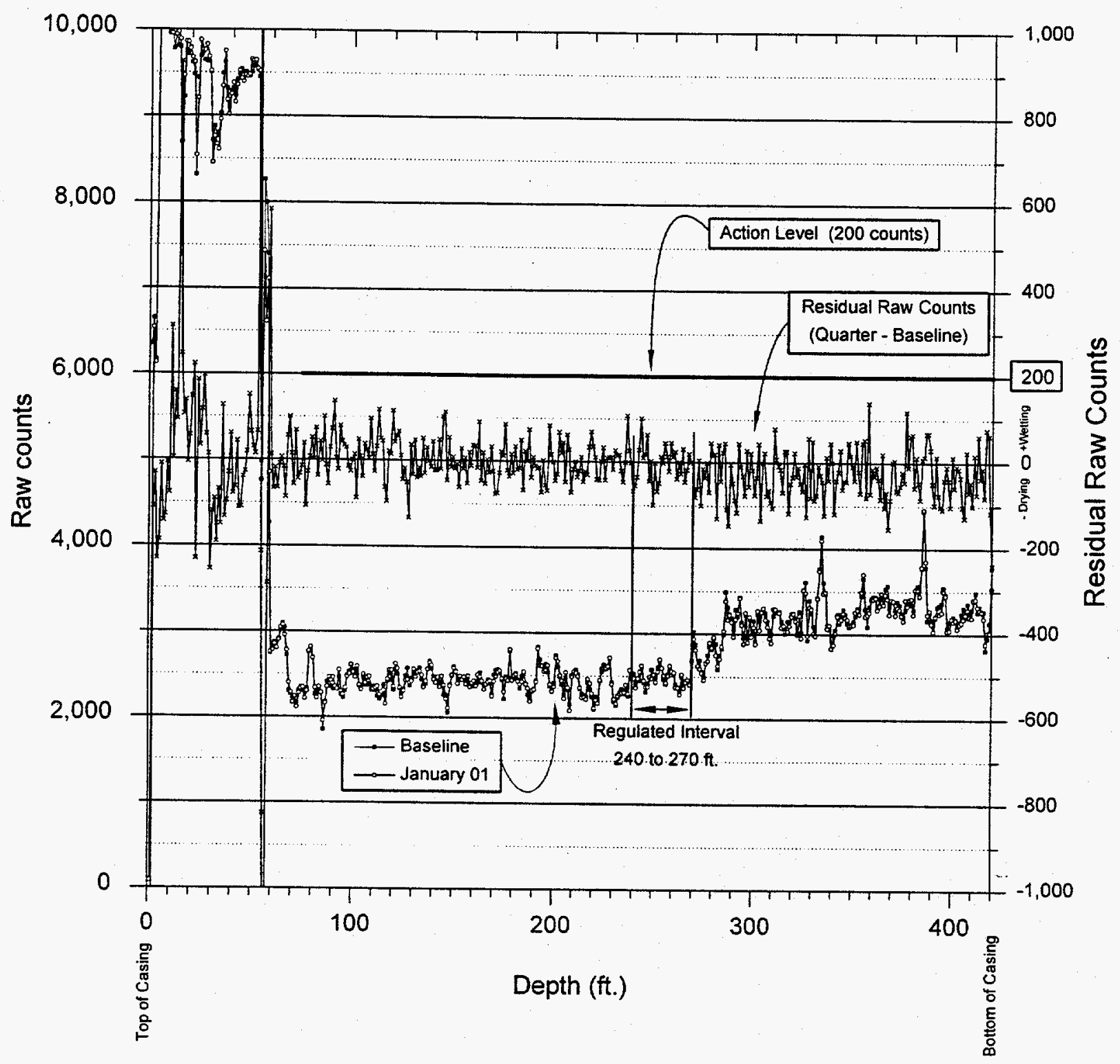

FIGURE PS-2. ER3-3 BASELINE DIFFERENCE FIRST QUARTER 
Post Closure Monitoring Report - CAU No. 91 Section: PROJECT SUMMARY

\section{ER3-3 Soil Moisture Monitoring}

\section{Baseline Difference}

\section{April $20012^{\text {nd }}$ Quarter}

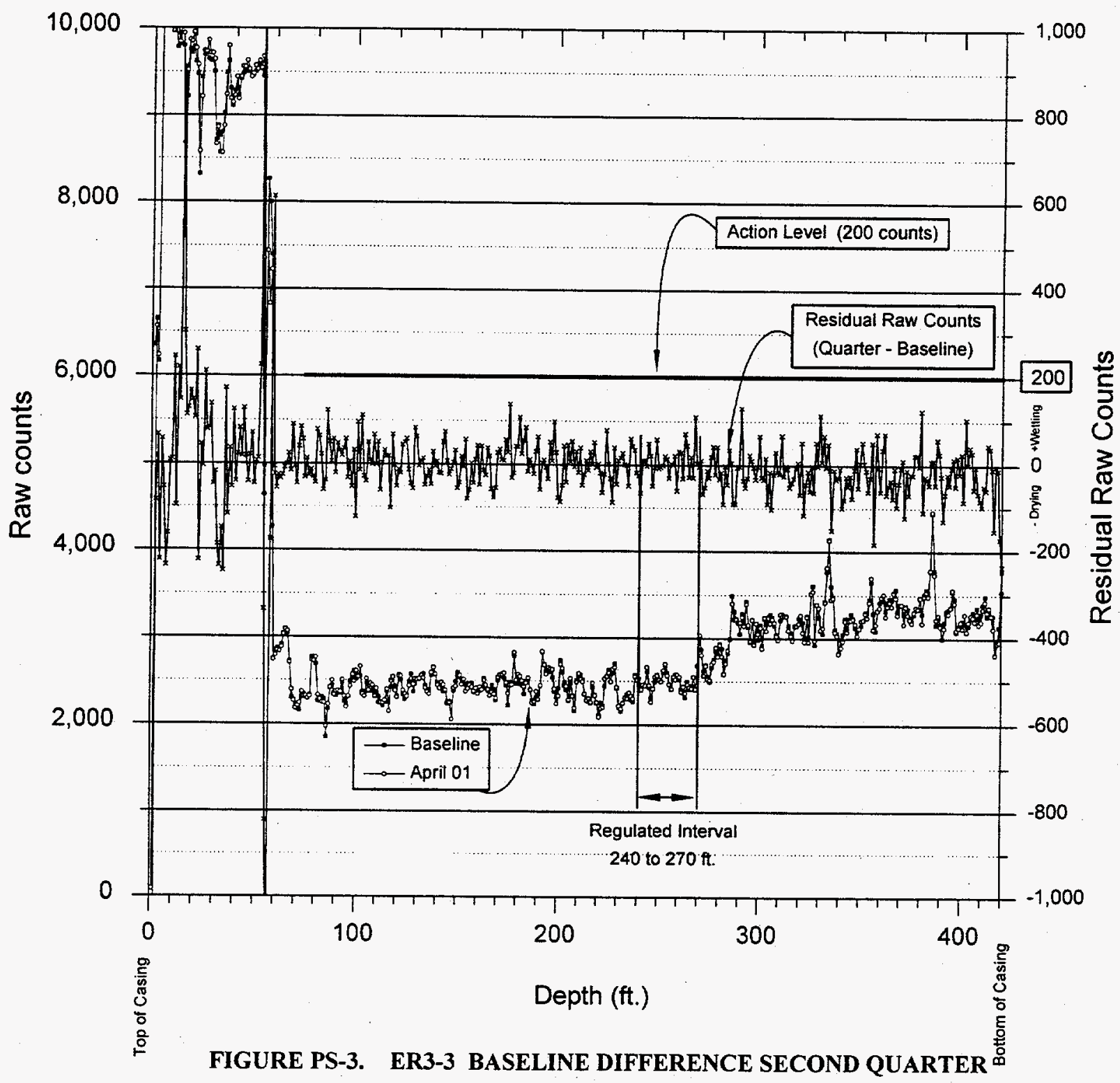


Post Closure Monitoring Repon - CAU No. 91 Section: PROJECT SUMMARY

\section{ER3-3 Soil Moisture Monitoring} Baseline Difference July $20013^{\text {rd }}$ Quarter

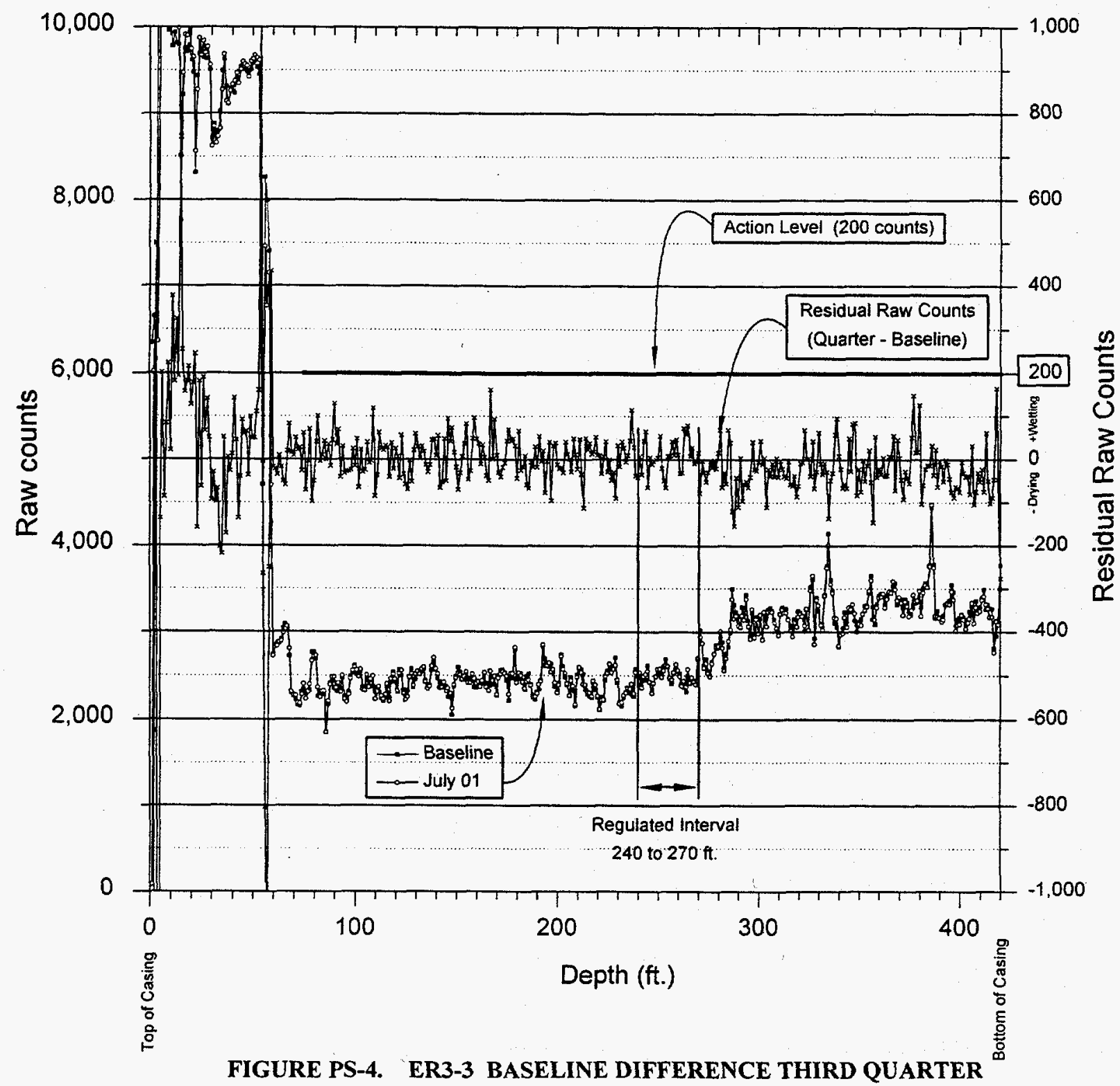


Post Closure Monitoring Report - CAU No. 91 Section: PROJECT SUMMARY

Revision: 0

Date: January 10, 2002

ER3-3 Soil Moisture Monitoring Baseline Difference

October $20014^{\text {th }}$ Quarter

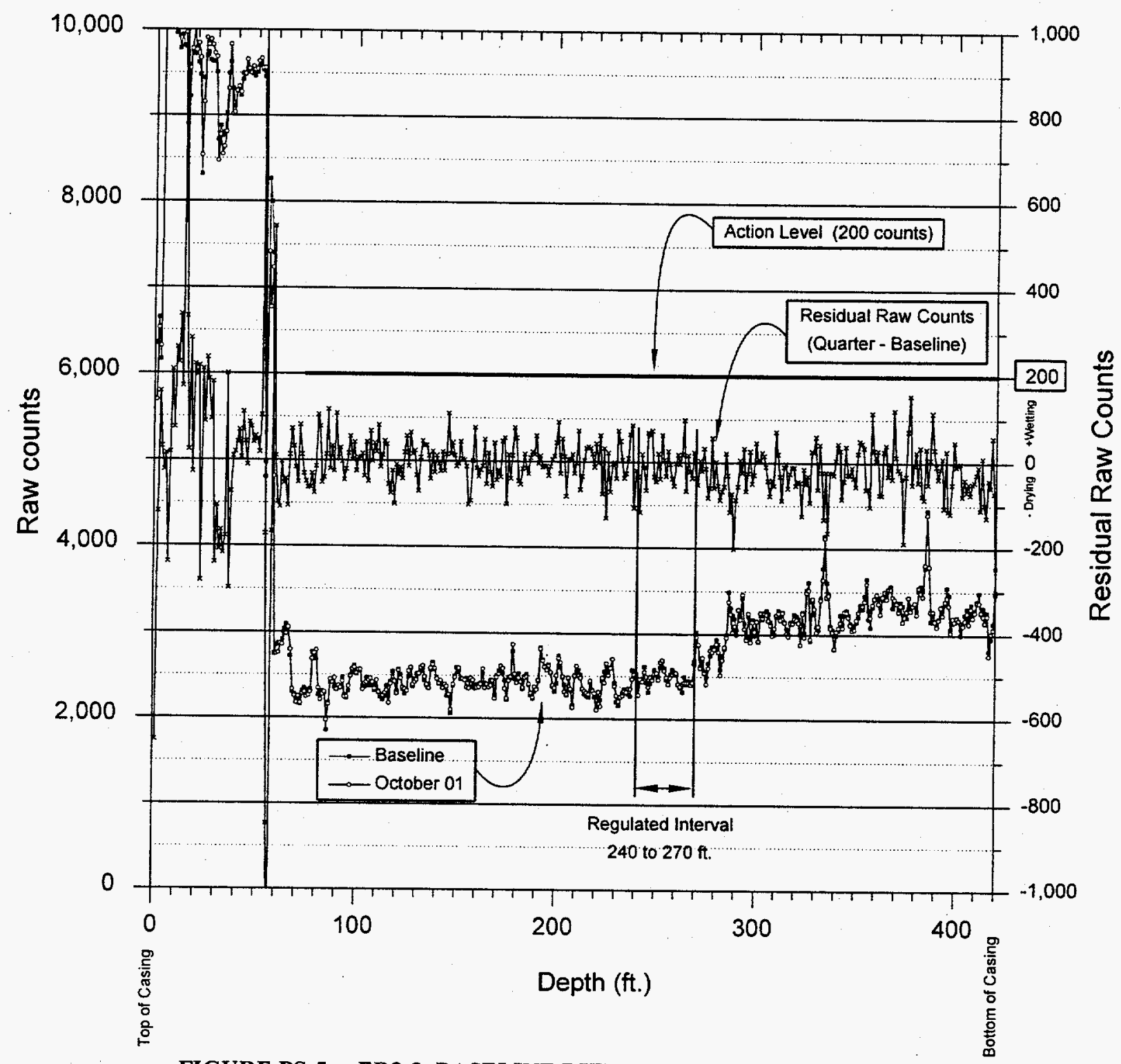

FIGURE PS-5. ER3-3 BASELINE DIFFERENCE FOURTH QUARTER 
Post Closure Monitoring Report - CAU No. 91

Section: PROJECT SUMMARY

Revision: 0

Date: January 10. 2002

\section{THIS PAGE INTENTIONALLY LEFT BLANK}




\subsection{INTRODUCTION}

\subsection{SCOPE AND OBJECTIVE}

This annual neutron soil moisture monitoring report provides an analysis and summary for site inspections, meteorological information, and neutron soil moisture monitoring data obtained at the Area 3 U-3fi Injection Well Unit. The U-3fi Injection Well is located in Area 3 of the Nevada Site (NTS), Nye County, Nevada. This report on the U-3fi Closure covers the period October 2000 to October 2001.

Inspections of the Area 3 U-3fi Injection Well are conducted to determine and document the physical condition of the covers, facilities, and any unusual conditions that could impact the proper operation of the waste disposal unit closure.

The objective of the neutron-logging program is to monitor the stability in soil moisture conditions along the 128 meters $(\mathrm{m})$ (420 feet [ft]) of ER3-3 Well and detect changes that may be indicative of moisture movement in the regulated interval of 73.2 to $82.3 \mathrm{~m}(240$ to $270 \mathrm{ft}$ ).

\subsection{SITE HISTORY}

The U-3fi Waste Disposal Unit is located in Area 3 at the NTS, Nye County, Nevada. The NTS is approximately 105 kilometers $(\mathrm{km})$ (65 miles [mi]) northwest of Las Vegas, Nevada (Figure 1).

The U-3fi Waste Disposal Unit is an abandoned Los Alamos National Laboratory (LANL) emplacement hole (Figure 2). It was drilled by Reynolds Electrical and Engineering Co., Inc. (REECo) between March 27, 1967 and April 24, 1967, for emplacement of a nuclear explosive device. A detailed history of the emplacement hole drilling program is found in the U-3fi Waste Disposal Unit Closure Plan (U.S. Department of Energy, Nevada Operations Office [DOE/NV], 1995b). On April 11, 1967, the hole reached a depth of $256 \mathrm{~m}(841 \mathrm{ft})$ below the surface. Due to formation conditions, a thicker drilling foam was introduced into the hole. Unfortunately, this did not work and the hole started caving in and the drill bit was trapped at a depth of $254.8 \mathrm{~m}$ $(836 \mathrm{ft})$. There were a number of attempts to retrieve the drill bit but all attempts failed. The top

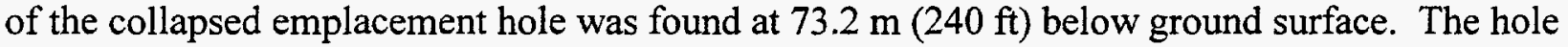
was abandoned on April 24, 1967.

The U-3fi Waste Disposal Unit was established in 1970 as a disposal site for radiologically contaminated waste primarily for post-shot "high-grading" wash water, which was solidified with cement and drill cores (Tattro, 1989). 
Date: January 10,2002

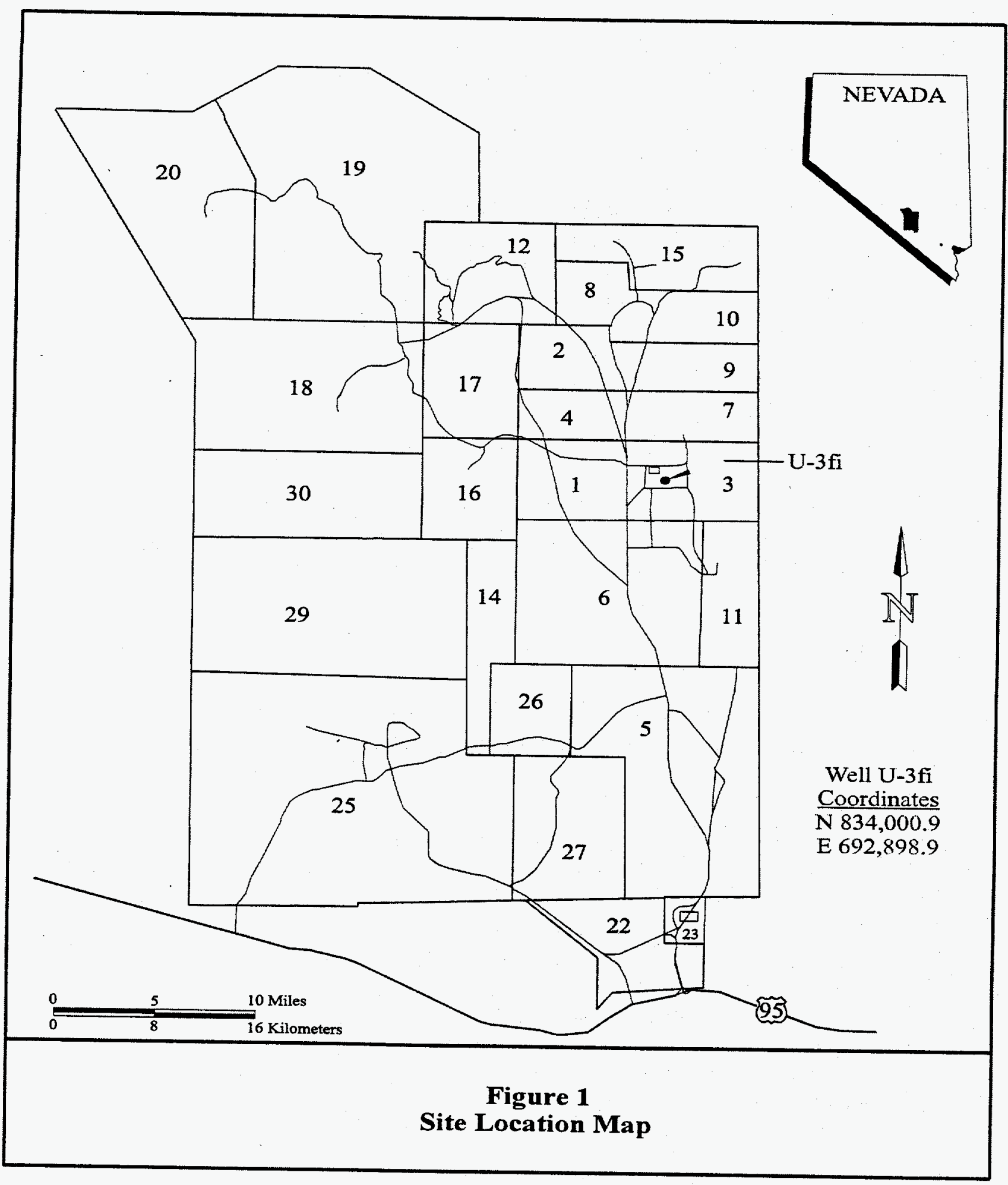




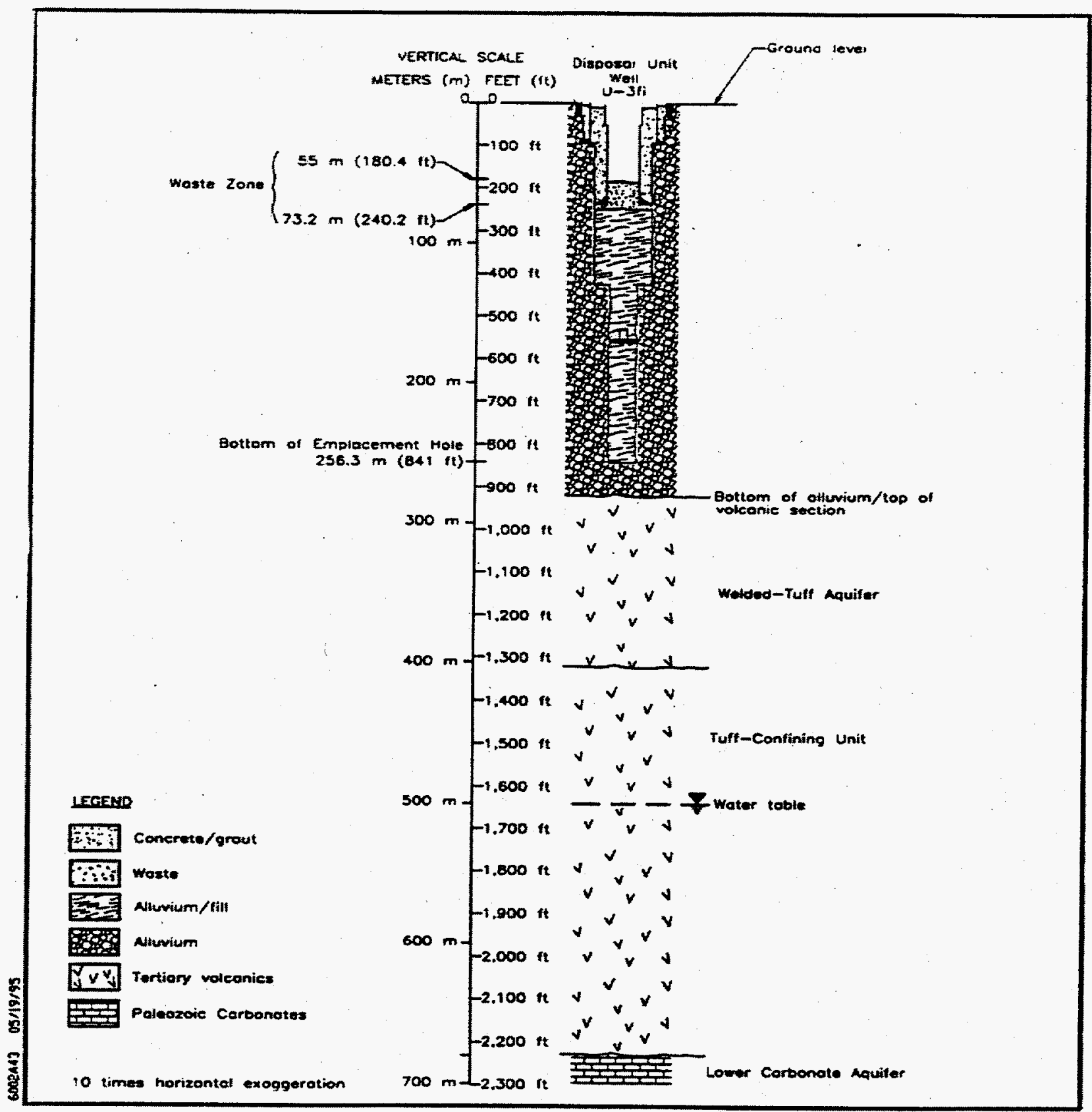

Figure 2

Cross Section of the U-3fi Waste Disposal Unit 
The U-3fi Waste Disposal Unit primarily received core samples and solidified decontamination wastes. Core samples consisted of mixed fission and activation products from the solidification detonation debris/melt during post-shot drilling (U.S. Department of Energy [DOE], 1988). While under LANL control, only LANL solid drillback waste was disposed in the U-3fi Waste Disposal Unit. Control of the U-3fi Waste Disposal Unit was assumed in 1977 by the U.S. Atomic Energy Commission, predecessor of the Energy Research and Development Administration, now the DOE. At this time, four additional waste generators, Lawrence Livermore National Laboratory, Area 6 Decontamination Pad, Area 12 Tunnels, and LRY3 (an unspecified generator of weapons test program waste) began disposing their waste in the U-3fi Waste Disposal Unit.

Waste disposal record keeping for the U-3fi Waste Disposal Unit began in 1977. The database, established and maintained by REECo Defense Waste Management Department, currently the Bechtel Nevada (BN) Waste Management Project, has 102 entries between January 11, 1977 and November 28, 1988. Access to the U-3fi Waste Disposal Unit from 1977 to 1989 was through both REECo Radiation Safety and Wackenhut Services, Inc. Copies of the waste disposal documents are found in Appendix C of the U-3fi Waste Disposal Unit Closure Plan (DOE/NV, 1995b).

According to waste disposal records, it is estimated that 86.34 curies (3,181 gigabecquerel) (1.7 kilograms [3.7 pounds]) of fission products from drilling activities were placed in the Waste Disposal Unit. Chromium from drilling mud and lead from pipe-lubricant, stemming, and shielding materials may also be present. Waste was placed from a depth of $54.9 \mathrm{~m}(180 \mathrm{ft})$ to approximately $73.2 \mathrm{~m}$ (240 ft) below ground surface (bgs).

Subsurface characterization activities began in November 1994 with the installation of the ODEX borehole ER3-3. The objectives of this study were to determine if constituents of concern were present in the subsurface and to assess the potential for migration of these constituents of concern from the waste zone to the surrounding formation.

The ER3-3 borehole is located $18.3 \mathrm{~m}(60 \mathrm{ft})$ south of U-3fi and drilled at a design angle of 6 degrees from the vertical in order to intercept the U-3fi emplacement borehole at

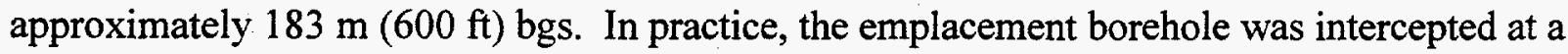

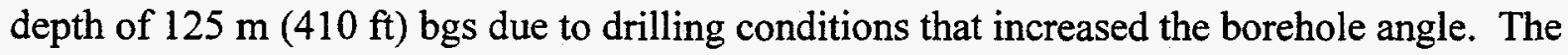
borehole reached a total depth of $130 \mathrm{~m}(425 \mathrm{ft})$ in February 1995.

Cuttings and core samples were recovered during drilling operations that were used to understand the geologic, lithologic, and hydrologic soil properties surrounding the U-3fi Waste Disposal Unit. The results of these studies are discussed in the U-3fi Post-Closure Plan (DOE/NV, 1995c).

The ER3-3 borehole was completed as a neutron-probe soil moisture monitoring well by removing the ODEX casing and stemming a single-wall steel casing in place with a sand backfill. The monitoring well is located entirely within the vadose zone and extends from the surface to a 


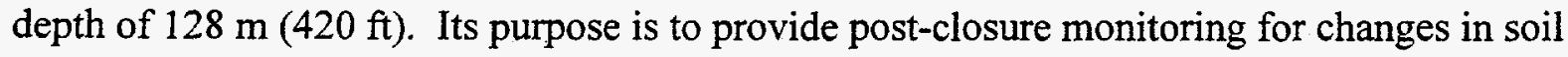
moisture content that would indicate moisture migration in the vicinity of the waste and to detect subsidence of material in the U-3fi Borehole.

The Post-Closure Plan (DOE/NV, 1995c) was approved by the Nevada Division of Environmental Protection (NDEP) on August 28, 1995. The DOE/NV Project Manager authorized closure of the Waste Disposal Unit at that time.

On September 6, 1995, the stemming activities in U-3fi began with the placement of

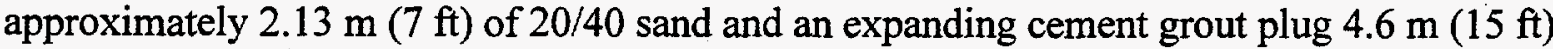
thick. Once this plug was allowed to set, the casing was filled with $32.6 \mathrm{~m}$ (107 ft) of NTS fine stemming sand and grouted with an expanding cement plug $13.7 \mathrm{~m}(45 \mathrm{ft})$ thick. On September 28, 1995, the U-3fi Waste Disposal Unit was declared closed.

Post-closure monitoring activities, detailed in the Post-Closure Plan (DOE/NV, 1995c), specified that a neutron monitoring program was to be based upon monitoring and reporting changes in absolute moisture content. The Action Level criteria for tracking and reporting to the NDEP was specified as the observance of a 5 percent relative increase in volumetric moisture content for two or more consecutive monitoring periods. As originally designed, the ER3-3 Well was to be used for obtaining raw neutron counts. This new specification would require a complicated and expensive compound calibration for determining absolute soil moisture content in the telescoping sand-packed borehole. In December 1995, representatives of NDEP, DOE/NV, and BN agreed that considering the $73.2-\mathrm{m}(240-\mathrm{ft})$ depth of the regulated interval and the dry climatic conditions, no changes in moisture content would be expected. Therefore, the high cost of calibrating for the ER3-3 borehole geometry was not justified and a relatively simple program of monitoring for changes in raw counts would be sufficient as long as the alternative proposal was more conservative than the absolute Action Levels initially presented.

The first baseline neutron log from ER3-3 was obtained in July 1995 . The first year of monitoring established the baseline conditions. The first quarterly monitoring was conducted in October 1996.

In September 1996, DOE/NV formally petitioned NDEP to change the Action Level to a 200 count change from baseline conditions in the 73.2 to $82.3-\mathrm{m}$ ( 240 to $270-\mathrm{ft}$ ) regulated interval. This request was based on a statistical analysis of the expected rate of occurrence of false positives and false negatives in a 20 -year period.

A Class One Modification to adjust the monitoring criteria in Section V of the Historic RCRA Units (NDEP, 1997) for the Area 3 U-3fi Injection Well was adopted on May 31, 1997.

Significant events for the U-3fi Waste Disposal Unit are summarized in Table 1. 
TABLE 1 - CHRONOLOGY OF THE AREA 3 U-3fI INJECTION WELL

\begin{tabular}{|c|c|}
\hline DATE & SIGNIFICANT EVENTS \\
\hline 1970 & $\begin{array}{l}\text { U-3fi Waste Disposal Unit established as disposal site for radiologically contaminated waste } \\
\text { consisting of solidified post-shot wastewater and drill cores. }\end{array}$ \\
\hline 1989 & Waste no longer accepted for disposal in U-3fi Waste Disposal Unit. \\
\hline 1994 & $\begin{array}{l}\text { Subsurface site characterization studies began in November } 1994 \text { with installation of Borehole } \\
\text { ER3-3. Borehole was drilled } 13.3 \mathrm{~m}(60 \mathrm{ft}) \text { south of } \mathrm{U}-3 \mathrm{fi} \text { at an angle of } 6^{\circ} \text { to a depth of } 130 \mathrm{~m} \\
(425 \mathrm{ft}) \text {. }\end{array}$ \\
\hline \multirow{6}{*}{1995} & $\begin{array}{l}\text { Resource Conservation and Recovery Act Industrial Site Environmental Restoration Closure } \\
\text { Plan. Area 3 U-3 fi Waste Unit, draft issued June } 1995 \text { (DOE/NV, 1995b). }\end{array}$ \\
\hline & $\begin{array}{l}\text { Resource Conservation and Recovery Act Industrial Sites Environmental Restoration Post- } \\
\text { Closure Plan, Area 3 U-3fi Waste Unit, issued August } 1995 \text { (DOENNV, 1995c). }\end{array}$ \\
\hline & First-year neutron baseline data set started in July. \\
\hline & September 6, 1995 stemming and grouting activities begin in U-3fi Waste Disposal Unit. \\
\hline & September 28, 1995 U-3fi Waste Disposal Unit was declared closed. \\
\hline & $\begin{array}{l}\text { Area } 3 \text { U-3fi Waste Unit Resource Conservation and Recovery Act Closure Report, issued } \\
\text { November } 1995 \text { (DOE/NV, 1995a). }\end{array}$ \\
\hline \multirow[t]{2}{*}{1996} & $\begin{array}{l}\text { DOE/NV petitions NDEP to change the Action Level to } 200 \text { counts above baseline conditions in } \\
\text { the regulated interval. }\end{array}$ \\
\hline & First quarterly monitoring began in October 1996. \\
\hline \multirow{3}{*}{1997} & $\begin{array}{l}\text { First Annual Report RCRA Post-Closure Monitoring and Inspections for the U-3fi Waste Unit for } \\
\text { the Period July } 1995 \text { - October 1996, issued in January } 1997 \text { (DOE/NV, 1997). }\end{array}$ \\
\hline & $\begin{array}{l}\text { A Class One Modification to adjust the monitoring criteria in Section V of the Historic RCRA } \\
\text { Units (Permit No. NEV HW009) for the U-3fi Injection Well was adopted on May } 31,1997 .\end{array}$ \\
\hline & $\begin{array}{l}\text { During first-quarter logging, the neutron logging tool } \# 7074 \text { separated from cable and was } \\
\text { irreparably damaged in the fall. A backup instrument was calibrated to replace } \# 7074 \text {. }\end{array}$ \\
\hline 2000 & $\begin{array}{l}\text { Required 5-year directional survey run on ER3-3 access casing. No subsidence of casing was } \\
\text { indicated. }\end{array}$ \\
\hline
\end{tabular}




\subsection{SITE GEOLOGY AND HYDROLOGY}

The U-3fi Injection Well is located in the west central portion of Yucca Flat in Area 3 of the NTS, Nye County, Nevada (834004 N, 692900 E).

Yucca Flat is located within the Ash Meadows groundwater subbasin (Waddel, 1982). Regional groundwater flow is assumed to be south-southwest. Discharge occurs primarily in Ash Meadows, located approximately $80 \mathrm{~km}(50 \mathrm{mi})$ to the south-southwest.

The U-3fi emplacement hole extends to approximately $256 \mathrm{~m}(841 \mathrm{ft})$ and is hosted in Quaternary and Tertiary alluvial deposits which extend locally to about $274 \mathrm{~m}(900 \mathrm{ft})$. These deposits are variably cemented, moderately sorted sand and gravel derived from local hills. Beneath the alluvium, a Tertiary volcanic sequence extends from about $274 \mathrm{~m}(900 \mathrm{ft})$ to about $671 \mathrm{~m}(2,200 \mathrm{ft})$. These rocks form two hydrogeologic units; the welded tuff aquifer and the tuff-confining unit (Winograd et al., 1975). The water table beneath U-3fi occurs within the tuffconfining unit at approximately $488 \mathrm{~m}(1,600 \mathrm{ft})$. Underlying the volcanic sequence is the Lower Carbonate Aquifer, which is comprised of Paleozoic limestones and dolomites. These rocks are complexly faulted and form the primary groundwater transport path towards the Ash Meadows discharge point. The lower carbonate aquifer is estimated to be approximately $1,000 \mathrm{~m}(3,300 \mathrm{ft})$ thick beneath the U-3fi Waste Disposal Unit. Vertical migration of groundwater beneath U-3fi Waste Disposal Unit is controlled by the tuff-confining unit. Lateral (regional) migration is controlled by the lower carbonate aquifer.

Annual precipitation at Well ER6-1, located approximately $10 \mathrm{~km}(6.2 \mathrm{mi})$ south of U-3fi Waste Disposal Unit, is 12.52 centimeters $(\mathrm{cm})$ (4.93 inches [in]). Estimates of Potential Evapotranspiration obtained from characterization studies in Area 5 indicate Potential Evapotranspiration of about 157.5 centimeters/year (62 inches/year), which is significantly higher than the mean annual precipitation. Recharge to the subsurface is believed to be nonexistent. 
Post Closure Monitoring Report - CAU No. 91 Section: INTRODUCTION

Revision: 0

Date: Januan: 10, 2002

THIS PAGE INTENTIONALLY LEFT BLANK 


\subsection{REGULATORY CRITERIA}

\subsection{BACKGROUND}

Section 4.0 of the Post-Closure Plan (DOE/NV, 1995c) specified a neutron monitoring program that is to be based upon monitoring and reporting changes in absolute volumetric soil moisture content. An action criteria for tracking and reporting to the NDEP was specified (Section 4.1.2) as the observance of a 5 percent relative increase in volumetric moisture content for more than two consecutive monitoring periods. Because the well was designed for obtaining raw neutron counts, this specification would have required a complicated and expensive compound calibration for determining absolute soil moisture content in the telescoping, sand-packed borehole. Implementation of this strategy would be both costly and problematic.

In a meeting with representatives from NDEP, DOE/NV, and BN in December 1995, it was requested by DOE/NV that the monitoring strategy be changed for two reasons. The first was that the benefits of obtaining a compound calibration for absolute moisture content are offset by the high cost of calibrating for the ER3-3 hole geometry. The second, considering the depth of the regulated interval and dry climatic conditions at the NTS, changes in moisture content are not expected. Therefore, a relatively simple program of monitoring for changes in raw neutron counts would be both conservative and sufficient. It was agreed that it did not make sense to calibrate the neutron probe for the ER3-3 geometry, but that any alternative proposal must be more conservative than the absolute volumetric moisture content Action Levels initially presented. In addition, it was agreed to obtain up to 12 months of baseline neutron data and then propose an alternative monitoring plan to NDEP.

The proposed alternative to an absolute calibration was to use "statistically significant" changes in raw counts from the neutron tool to determine when an increase in moisture content occurred in the regulated interval.

The philosophy in using this approach is guided by two criteria:

1). Considering both the depth to the regulated interval and the arid site conditions, no change was expected due to surface rainfall events and infiltration. Therefore, any changes above the system noise level could be considered significant regardless of the change in absolute moisture content. Consequentially, calibration of the neutron gauge to local geometries and soil conditions would not be required.

2). Because the proposed monitoring is based on changes in raw counts, and not on the absolute moisture content, the criteria for setting an Action Level should be 
more conservative than what would be set when using an absolute soil moisture content.

Considering the above-stated criteria, a conservative choice for the Action Level would be "any statistically significant changes greater than some small multiple of the system noise level." A statistical method called the Bootstrap (Bradley and Tibshirani, 1993) was run using the one-year baseline data set to provide the statistical character of the system noise and a 20-year acceptance rate of about 2 percent for both false positives and false negatives. The simulation was carried out to 2,000 years of quarterly monitoring ( 8,000 observations) in the 73.2 to $82.3-\mathrm{m}$ ( 240 to $270-\mathrm{ft}$ ) regulated interval. For an acceptance rate of 2 percent, an Action Level of 200 count change from baseline conditions was found to meet the design criteria. Details of this process can be found in the first annual report (DOE/NV, 1997) and a letter discussing the technical basis (DOENV, 1996).

In October 1996, a formal proposal (DOE/NV, 1996) from DOE/NV was submitted to NDEP requesting that the post-closure monitoring activities be modified to reflect an Action Level based on a change in raw neutron counts of 200 counts in the regulated interval. NDEP approved this request on December 9, 1996 (NDEP, 1996).

A Class One Permit Modification incorporating the criteria provided in the December 1996 letter requesting changes in the Post-Closure Plan (DOE/NV, 1995c) was issued on May 31, 1997.

\subsection{SITE INSPECTION COMPLIANCE CRITERIA}

Prior to conducting a post-closure inspection, design drawings, aerial photographs, and site maintenance records are reviewed to provide a basis for evaluating site conditions. The site inspection includes a walking inspection of the entire site within $304 \mathrm{~m}(1,000 \mathrm{ft})$ of the U-3fi Waste Disposal Unit and photo documentation. The Post-Closure Inspection Checklist (Appendix A) details items of concern under the following topics:

- $\quad$ Adjacent off-site features in the watershed areas up-slope of the unit, such as new roads and erosion channels.

- $\quad$ Access roads, fences, gates, and signs.

- Monuments and other permanent features.

- U-3fi waste cover.

- $\quad$ Site drainage features.

- $\quad$ Monitoring Well ER3-3. 
Post Closure Monitoring Repor - CAU No. 91

\subsection{SOIL MOISTURE MONITORING COMPLIANCE CRITERIA}

Soil moisture compliance monitoring is performed following the May 31, 1997, Class One Modification of the NDEP permit for a Hazardous Waste Management Facility, Permit Number NEV HW009 (NDEP, 1997). The Class One Permit Modification incorporated the criteria presented in the December 1996 letter (DOE/NV, 1996) requesting changes in the Post-Closure Plan (DOE/NV, 1995c).

The ER3-3 post-closure monitoring criteria requires notification to the NDEP if the residual raw neutron counts (Observed Raw Counts minus Baseline Raw Counts) exceeds the 200 count Action Level in the regulated interval extending between 73.2 to $82.3 \mathrm{~m} \mathrm{(240} \mathrm{to} 270 \mathrm{ft}$ ) for two or more consecutive quarterly monitoring periods. The post-closure monitoring criteria also requires notification to the NDEP if settling in the U-3fi Borehole has occurred on a scale large enough to cause shearing of the lower portion of the ER3-3 Monitoring Well. A borehole gyroscopic survey is conducted every five years to determine if the borehole casing is being subjected to stresses which may be indicative of subsidence within the U-3fi emplacement borehole. 
Post Closure Monitoring Repon - CAU No. 91 Section: REGULATORY

Revision: 0

Date: January 10.2002

\section{THIS PAGE INTENTIONALLY LEFT BLANK}




\subsection{SITE INSPECTIONS AND ANNUAL SUBSIDENCE SURVEY}

\subsection{INTRODUCTION}

To comply with the post-closure care requirements, formal site inspections have been conducted twice a year since the closure of the unit in September 1995. The inspections were completed to evaluate the performance and maintenance needs of the unit in accordance with the requirements of Title 40 Code of Federal Regulations $\$ 265.15$ and the RCRA Part B Permit. A complete inspection package includes copies of the inspection checklist, field logbook notes, site photographs, and the inspector's current resume. Copies of the Post-Closure Care inspection checklist and associated field notes for March 2001 and September 2001 are found in Appendix A. Copies of site photographs and inspectors' resumes can be obtained by contacting the DOE/NV, Environmental Restoration Division.

\subsection{FINDINGS FROM THE SITE INSPECTIONS}

The site is in good condition. Four site identification signs were noted as peeling during the March inspection and were replaced by the September inspection. Minor hairline cracking was identified on the U3fi Waste Disposal Unit concrete pad and the ER3-3 Monitoring Well concrete pad. However, this cracking is not progressing and does not threaten the integrity of the concrete pads. Vegetation was observed growing on the soil cover during the September inspection and had not yet been removed by the end of this reporting period. Removal of the vegetation is scheduled to be completed before the next semiannual inspection (March 2002).

\subsection{ANNUAL SUBSIDENCE SURVEY}

A subsidence monument was installed in the cement plug on the U-3fi cover and surveyed on September 18, 1995. This monument provides elevation control to determine if subsidence of the cement plug or soil surrounding the U-3fi Waste Disposal Unit is occurring. The Subsidence Survey Plat is found in Appendix B.

On September 5, 1996, the first-year subsidence survey was conducted and determined that the original survey was invalid because the survey had been run without a proper closure (DOE/NV, 1997). Because of this, the September 5, 1996 survey, with a control elevation of $1,230.84 \mathrm{~m}$ $(4,038.18 \mathrm{ft})$, has been selected to represent the baseline elevation. All subsequent surveys will record subsidence relative to this datum.

A subsidence survey was completed on August 3, 1998, at the U-3fi monument. This elevation was recorded at $1,230.828 \mathrm{~m}(4,038.151 \mathrm{ft})$, which indicated a subsidence of $0.884 \mathrm{~cm}(0.029 \mathrm{ft})$ 
from the baseline control survey elevation of $1,230.84 \mathrm{~m}(4,038.18 \mathrm{ft})$ obtained on September 5 , 1996. A confirmation survey was run on September 1, 1998. This survey recorded a monument elevation of $1,230.831 \mathrm{~m}(4,038.159 \mathrm{ft})$, indicating a subsidence of $0.640 \mathrm{~cm}(0.021 \mathrm{ft})$.

The survey had a closure error from the northwest corner monument of $0.579 \mathrm{~cm}(0.019 \mathrm{ft})$. Due to the small subsidence (approximately $0.640 \mathrm{~cm}$ [ $0.021 \mathrm{ft}]$ ), it was unclear if this was a result of a previous survey error (incremental instrument error) or could be attributed to an actual subsidence of the monument itself. The average elevation $(1,230.83 \mathrm{~m}[4,038.16 \mathrm{ft}])$ of the August 3, 1998 and the September 1, 1998 surveys was used for the 1998 monument elevation.

The subsidence survey for the October 2000 to October 2001 monitoring period was completed in July 2001 with a monument elevation of $1,230.833 \mathrm{~m}(4,038.166 \mathrm{ft})$ which indicated a subsidence of $-0.427 \mathrm{~cm}(-0.014 \mathrm{ft})$ relative to the baseline survey of September 1996, and an slight decrease in elevation of $0.061 \mathrm{~cm}(0.002 \mathrm{ft})$ compared to the previous year, July 2000 . While the survey results show a negative subsidence after the baseline survey, the magnitude of these changes is so small as to be at the survey instrument resolution level and it is not clear if they represent subsidence or measurement error. There is no clear evidence of any subsidence of the monument.

\section{TABLE 2 - SUBSIDENCE MONUMENT U-3fi COORDINATES AND ELEVATIONS}

\begin{tabular}{|c|c|c|c|c|c|}
\hline \multirow{2}{*}{$\begin{array}{l}\text { SURVEY } \\
\text { DATE }\end{array}$} & \multicolumn{2}{|c|}{ COORDINATES $^{a}$} & \multirow{2}{*}{$\begin{array}{c}\text { ELEVATION }^{\mathrm{b}} \\
\text { TOP OF SM1 } \\
\text { MONUMENT } \\
\text { (Feet) } \\
\end{array}$} & \multirow{2}{*}{\multicolumn{2}{|c|}{$\begin{array}{c}\text { SUBSIDENCE } \\
\text { (Feet) }\end{array}$}} \\
\hline & NORTHING & EASTING & & & \\
\hline September 18,1995 & N 834004.0 & E 692900.3 & $(4,038.1)^{c}$ & \multicolumn{2}{|c|}{-} \\
\hline September 5, 1996 & N 834004.00 & E 692900.35 & $4,038.18$ & \multicolumn{2}{|c|}{ - } \\
\hline July 30,1997 & N 834004.00 & E 692900.35 & $4,038.18$ & \multicolumn{2}{|c|}{0.00} \\
\hline August 3,1998 & N 834004.00 & E 692900.35 & $4,038.151$ & -0.029 & \multirow{2}{*}{$\begin{array}{l}\text { Avg. } \\
-0.025\end{array}$} \\
\hline September $1,1998^{d}$ & N 834004.00 & E 692900.35 & $4,038.159$ & -0.021 & \\
\hline July 12,1999 & N 834004.00 & E 692900.35 & $4,038.16$ & \multicolumn{2}{|c|}{-0.02} \\
\hline July 31,2000 & N 834004.00 & E 692900.35 & $4,038.168$ & \multicolumn{2}{|c|}{-0.012} \\
\hline July 23,2001 & N 834004.00 & E 692900.35 & $4,038.166$ & \multicolumn{2}{|c|}{-0.014} \\
\hline
\end{tabular}

${ }^{a}$ All coordinates based on the Nevada State Plane Grid, Central Zone - North American Datum of 1983 in feet.

${ }^{b}$ All elevations based on the North American Vertical Datum of 1929 in feet.

${ }^{\mathfrak{c}}$ Elevation cannot be proven due to failure to perform a proper closure on the original survey.

September 5, 1996 survey will be used for the elevation control datum.

d Re-run confirmation survey. 


\subsection{SOIL MOISTURE MONITORING}

\subsection{INTRODUCTION}

The objective of the ER3-3 vadose zone monitoring program is to monitor the soil moisture condition in the 73.2 to $82.3-\mathrm{m}$ ( 240 to $270-\mathrm{ft}$ ) regulated interval to provide an early warning of the potential for leachate migration from the U-3fi Waste Disposal Unit into the subsurface. In addition, the monitoring system is used to monitor changes indicative of subsurface subsidence within the U-3fi Waste Disposal Unit.

The ER3-3 monitoring system uses a portable neutron moisture-logging tool to determine changes in the moisture content in soils surrounding the neutron access tube which intercepts the U-3fi emplacement hole. By monitoring changes in soil moisture content, it is possible to detect the movement of wetting fronts in the soils surrounding the bottom of the U-3fi casing. The detection of changes in soil moisture content in this area provides an early warning of the potential movement of leachate from the U-3fi Waste Disposal Unit to the surrounding environment, indicating possible failure of the grout plug.

The ER3-3 borehole is located $18.3 \mathrm{~m}(60 \mathrm{ft})$ south of the U-3fi Waste Disposal Unit and drilled at a design angle of $6^{\circ}$ from the vertical. The U-3fi emplacement borehole was intercepted at a depth of $125 \mathrm{~m}$ (410 ft) bgs, with a total depth of $129.5 \mathrm{~m}(425 \mathrm{ft})$. Logging is accomplished

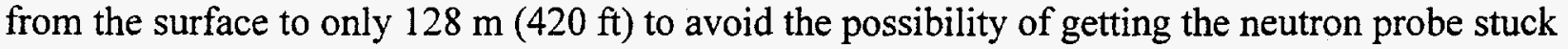
at the bottom of the access tube.

A Campbell Pacific Nuclear Hydroprobe (Model 503DR) containing a 50-millicurie (1.85-gigabecquerel) ${ }^{241}$ Americium/Beryllium neutron source is used to obtain moisture logs in the access tube. The tool is operated without a soil moisture calibration, recording raw neutron counts in a 16-second window.

\subsection{OPERATING PROCEDURES}

Neutron-logging operations adhere to BN Organization Instruction OI-2152.105, "Environmental Restoration Neutron Moisture Logging" (BN, 1999). The logging procedure was modified so that the downhole tool can operate without a centralizer. This was done because the neutron access tube is inclined at a $6^{\circ}$ angle. Field quality control operations require a daily standard count test to be run at the start and end of the day. Failure to pass this statistical test requires stopping operations, notifying the supervisor, and determining the cause.

Using this procedure, neutron logs are obtained by lowering the neutron tool to within $1.5 \mathrm{~m}$ $(5 \mathrm{ft})$ of the bottom of the access tube. The raw neutron count is obtained using a 16-second 
count time at $0.3-\mathrm{m}(1-\mathrm{ft})$ intervals along the length of the access tube. The data are recorded on field log sheets and stored in the data logger of the neutron probe as raw counts. The data logger is then downloaded to a personnel computer on a daily basis. Once the data have been reviewed, they are presented as two graphs: Cumulative Residual Neutron Counts and Baseline Difference. These graphs are discussed in Section 4.4.1, Data Presentation.

\subsection{PRECIPITATION DATA}

Precipitation data were collected from the National Weather Service Nuclear Support Office's CLINET Station Buster Jangle Y (BJY) located at $37^{\circ} 03^{\prime} 46^{\prime \prime} \mathrm{N}, 116^{\circ} 03^{\prime} 09^{\prime \prime} \mathrm{W}$, in Area 3 of the NTS. This station is located approximately $4.8 \mathrm{~km}$ (3 mi) northwest of Well ER3-3.

Precipitation records for this station for the period October 2000 through October 2001 are found in Appendix $\mathrm{C}$ and summarized in Table 3 and Figure 3.

The average annual precipitation over the period 1960 to 2001 at the BJY Station is $16.36 \mathrm{~cm}$ (6.44 in.). The annual precipitation (January 2001 through December 2001) is $15.49 \mathrm{~cm}$ (6.10 in.). The yearly precipitation for the current monitoring period, October 2000 through October 2001, is $15.72 \mathrm{~cm}$ (6.19 in.).

\subsection{SOIL MOISTURE MONITORING RESULTS}

\subsubsection{Data Presentation}

The Cumulative Residual Neutron Counts graph (Figure 4) tracks changes over time from baseline conditions relative to the regulatory level of concern (Action Level). The residual raw Counts are calculated by subtracting the first-year average neutron count (baseline) from the raw neutron count from each monitoring period. While the data are collected on a $0.3-\mathrm{m}(1-\mathrm{ft})$ interval, the Cumulative Residual Neutron Count graph only displays the residual count every $1.5 \mathrm{~m}(5 \mathrm{ft})$ in the regulated interval between 73.2 to $82.3 \mathrm{~m} \mathrm{(240} \mathrm{to} 270 \mathrm{ft}$ ). This corresponds to the point closest to the bottom of the U-3fi emplacement casing. The residual values are plotted as residual raw counts vs date for each $1.5-\mathrm{m}$ (5-ft) depth (Figure 4). The level of regulatory concern is indicated as a heavy line at the 200 count Action Level. Values exceeding this limit for two consecutive monitoring periods require notifying the NDEP as specified in the Part B RCRA Permit (NDEP, 1997).

The next four graphs, Baseline Difference (Figures 5 through 8), show the changes occurring for the four quarterly monitoring periods along the entire length of a neutron access tube relative to baseline conditions. It is calculated by subtracting the baseline (first-year average) neutron count from the current raw neutron count on a depth basis. The result of this subtraction is referred to as the residual raw count. The residual raw count is plotted along with the actual raw neutron counts of both the current and baseline data vs depth from the top of the casing. A positive residual neutron count indicates conditions at that depth and point in time that are wetter than 
baseline conditions, while negative values indicate dryer conditions. Repeatability and instrumentation noise are approximately \pm 100 counts and, as a result, the residual graph has a noisy chaotic character due to the absence of any signal. The Baseline Difference graph provides detailed information on the overall performance of the entire unit, while the Cumulative Residual graph focuses only on cumulative trends relative to the regulatory level of concern at a specific depth and is used to make compliance decisions.

TABLE 3 - PRECIPITATION DATA FOR THE BUSTER JANGLE Y, METEOROLOGICAL STATION BJY, AREA 3, NTS

\begin{tabular}{||l|c|c|c||}
\hline \multicolumn{1}{|c|}{ DATE } & $\begin{array}{c}\text { MONTHLY } \\
\text { AVERAGE } \\
(\mathbf{1 9 6 0 - 2 0 0 1 )} \\
\text { inches }^{2}\end{array}$ & $\begin{array}{c}\text { MONTHLY } \\
\text { CUMULATIVE } \\
\text { inches }^{\mathrm{a}}\end{array}$ & $\begin{array}{c}\text { YEARLY } \\
\text { CUMULATIVE } \\
\text { inches }\end{array}$ \\
\hline \hline October 2000 & 0.32 & 0.52 & 6.51 \\
\hline November 2000 & 0.51 & 0.12 & 6.63 \\
\hline December 2000 & 0.58 & 0.00 & 6.63 \\
\hline \hline January 2001 & 0.87 & 1.62 & 1.62 \\
\hline February 2001 & 0.93 & 1.45 & 3.07 \\
\hline March 2001 & 0.79 & 0.27 & 3.34 \\
\hline April 2001 & 0.36 & 0.23 & 3.57 \\
\hline May 2001 & 0.37 & 0.06 & 3.63 \\
\hline June 2001 & 0.25 & 0.00 & 3.63 \\
\hline July 2001 & 0.51 & 0.17 & 3.80 \\
\hline August 2001 & 0.62 & 1.21 & 5.01 \\
\hline September 2001 & 0.36 & 0.22 & 5.23 \\
\hline October 2001 & 0.32 & 0.32 & 5.55 \\
\hline
\end{tabular}

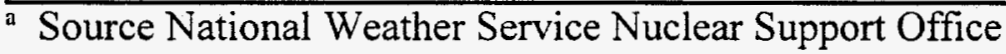


Post Closire Monitoring Report - CAU No. 91 Section: MONITORING

Date: Januany 10. 2002

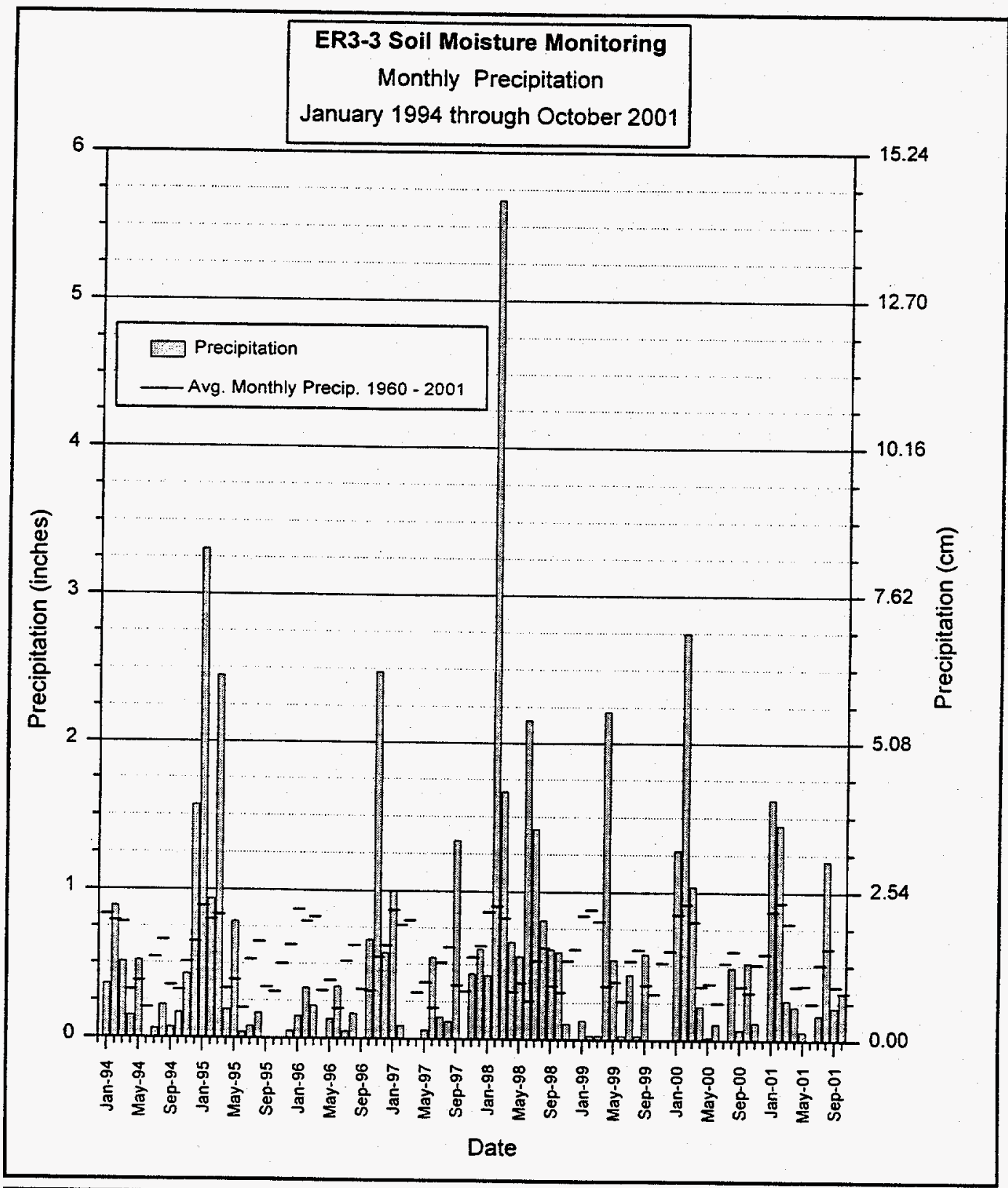

FIGURE 3 MONTHLY PRECIPITATION 


\subsubsection{Discussion of Analytical Data Trends}

The ER3-3 borehole is logged on a quarterly interval occurring in January, April, July, and October.

The Cumulative Residual Neutron Counts Graph (Figure 4) provides summary monitoring information over time with respect to the level of regulatory concern. The baseline data set, as indicated on the graph, was derived from the first ten months of data. Below the cumulative residual plot is the monthly cumulative precipitation obtained from the BJY Weather Station.

The Cumulative Residual Neutron Counts (Figure 4) in the regulated interval are plotted on a $0.3-\mathrm{m}(5-\mathrm{ft})$ spacing, by date, and indicate dry conditions with no trends evident.

The moisture content of the regulated interval between 73.2 to $82.3 \mathrm{~m}$ ( 240 to $270 \mathrm{ft}$ ) remains dry and stable, and is below the compliance Action Level of 200 counts.

Performance along the entire neutron access tube is found in the Baseline Difference graphs (Figures 5 through 8). These graphs show the raw neutron counts obtained from both the baseline data set and the current quarterly monitoring period as well as the residual counts (Quarter - Baseline) on a 0.3-m (1-ft) interval. This presentation is useful to determine moisture changes occurring outside of the regulated interval as well as monitoring for subsidence. The 200 count Action Level and the extent of the regulated interval are labeled for reference.

\subsubsection{January 2001 - First Quarter}

The January 2001 Baseline Difference graph is shown in Figure 5. Borehole conditions are observed to be dry and stable, with no trends or indications of subsidence evident in the data.

The area immediately beneath the cement plug shows an air gap with apparent "drying," which is probably due to the settling of the backfill in this area. This apparent drying trend extends from approximately 16.15 to $18.29 \mathrm{~m}(53$ to $60 \mathrm{ft})$ in the January and subsequent monitoring quarters. No significant change is noted from the prior October 2000 monitoring period.

The moisture content of the regulated interval between 73.2 to $82.3 \mathrm{~m} \mathrm{(240} \mathrm{to} 270 \mathrm{ft}$ ) remains dry and is below the compliance Action Level of 200 counts. There is no evidence of subsidence observed in the data.

\subsubsection{April 2001 - Second Quarter}

The April 2001 Baseline Difference graph is shown in Figure 6. No changes are observed in the air gap beneath the cement plug. Borehole conditions are observed to be dry and stable, with no trends or indications of subsidence evident in the data. 
The moisture content of the regulated interval between 73.2 to $82.3 \mathrm{~m} \mathrm{(} 240$ to $270 \mathrm{ft}$ ) remains dry, stable, and is below the compliance Action Level of 200 counts with no indications of subsidence.

\subsubsection{July 2001 - Third Quarter}

The July 2001 Baseline Difference graph is shown in Figure 7. This neutron log also indicates dry stable conditions extending from $21 \mathrm{~m}(70 \mathrm{ft})$ to depth with no evidence of subsidence.

The moisture content of the regulated interval between 73.2 to $82.3 \mathrm{~m}$ ( 240 to $270 \mathrm{ft}$ ) remains dry and stable and shows no signs of subsidence.

\subsubsection{October 2001 - Fourth Quarter}

The October 2001 Baseline Difference graph is shown in Figure 8: This neutron log also indicates dry and stable conditions extending from $21 \mathrm{~m} \mathrm{(70} \mathrm{ft)} \mathrm{to} \mathrm{depth,} \mathrm{with} \mathrm{no} \mathrm{indications} \mathrm{of}$ subsidence.

The moisture content of the regulated interval between 73.2 to $82.3 \mathrm{~m}$ ( 240 to $270 \mathrm{ft}$ ) remains dry and stable, and is below the Compliance Action Level of 200 counts with no indications of subsidence. 


\section{ER3-3 Soil Moisture Monitoring Cumulative Residual Neutron Counts} July 1995 through October 2001
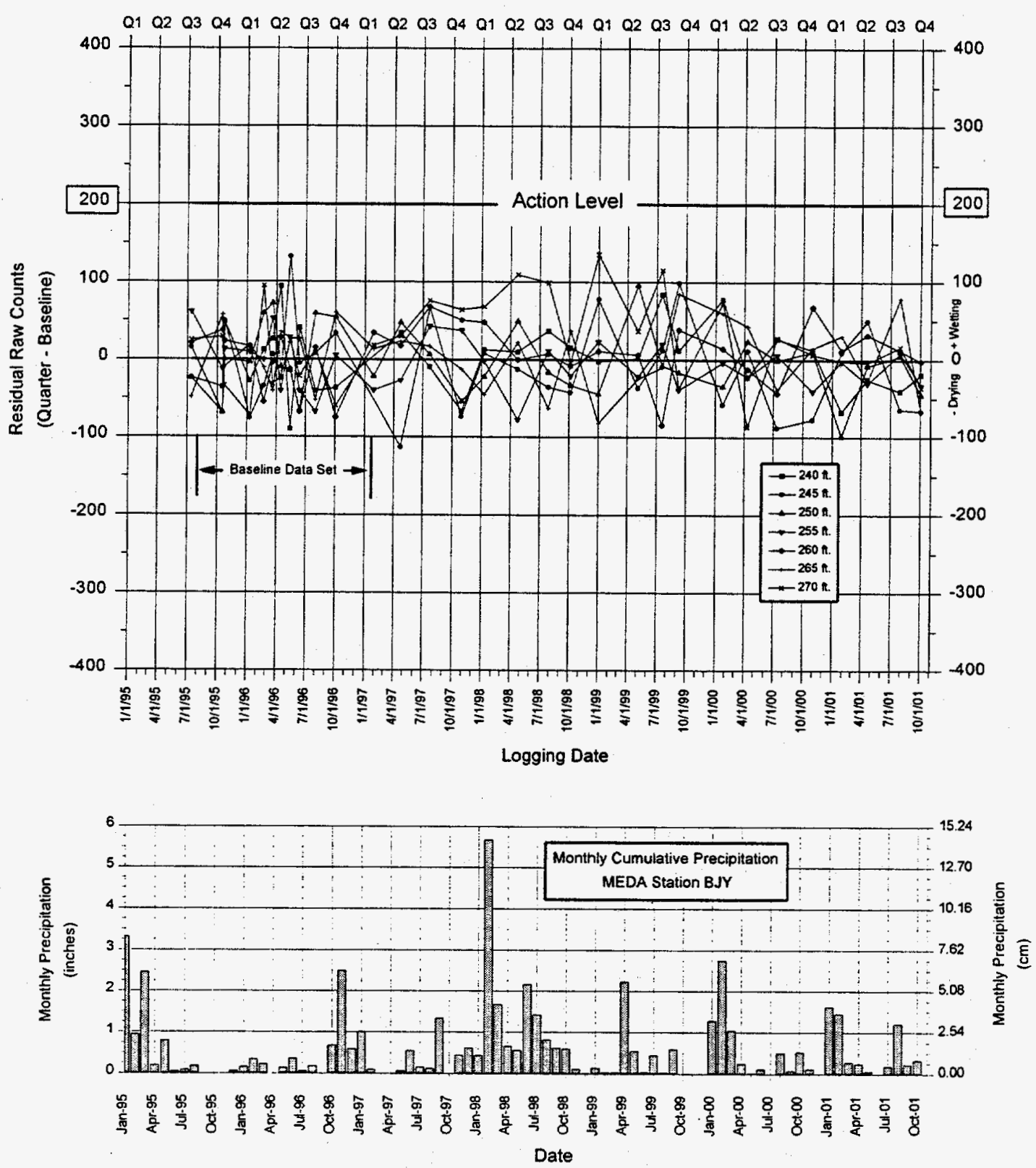

FIGURE 4. ER3-3 CUMULATIVE RESIDUAL NEUTRON COUNTS 
Post Closure Monitoring Report - CAU No. 91 Section: MONITORING

\section{ER3-3 Soil Moisture Monitoring}

Baseline Difference

January $20011^{\text {st }}$ Quarter

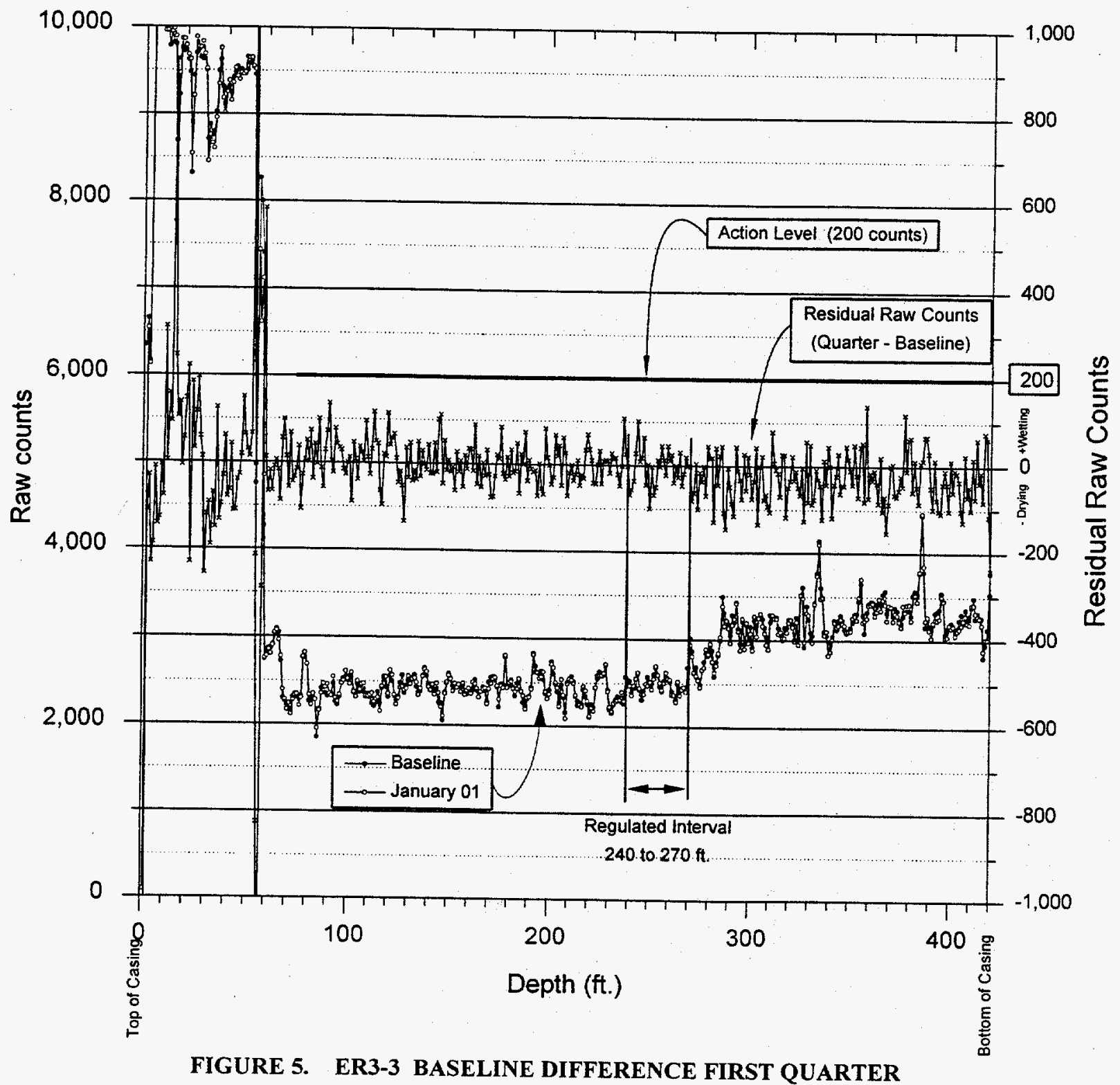


Date: January 10.2002

\section{ER3-3 Soil Moisture Monitoring}

Baseline Difference

April $2001.2^{\text {nd }}$ Quarter

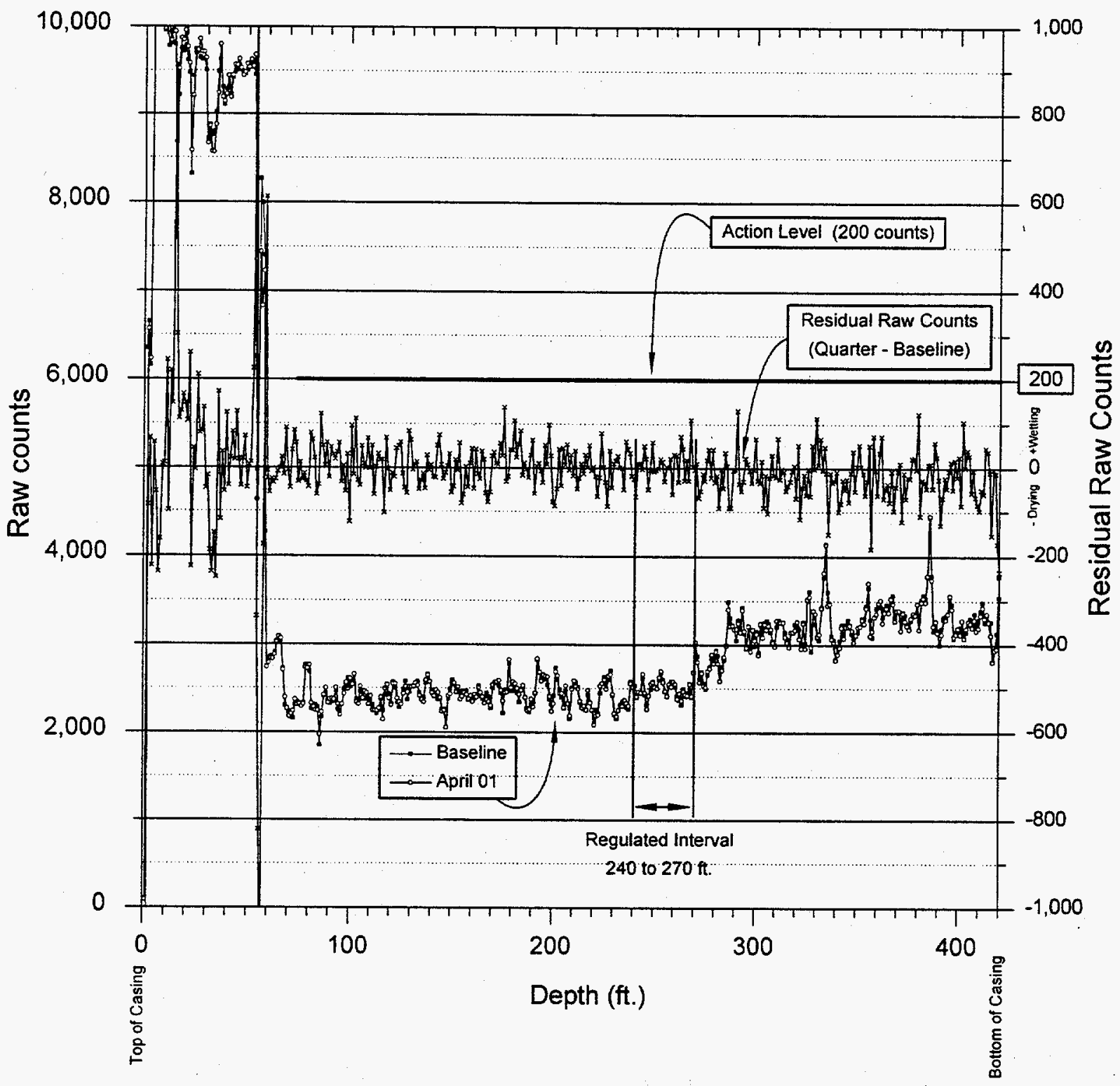

FIGURE 6. ER3-3 BASELINE DIFFERENCE SECOND QUARTER 
ER3-3 Soil Moisture Monitoring

Baseline Difference

July $20013^{\text {rd }}$ Quarter

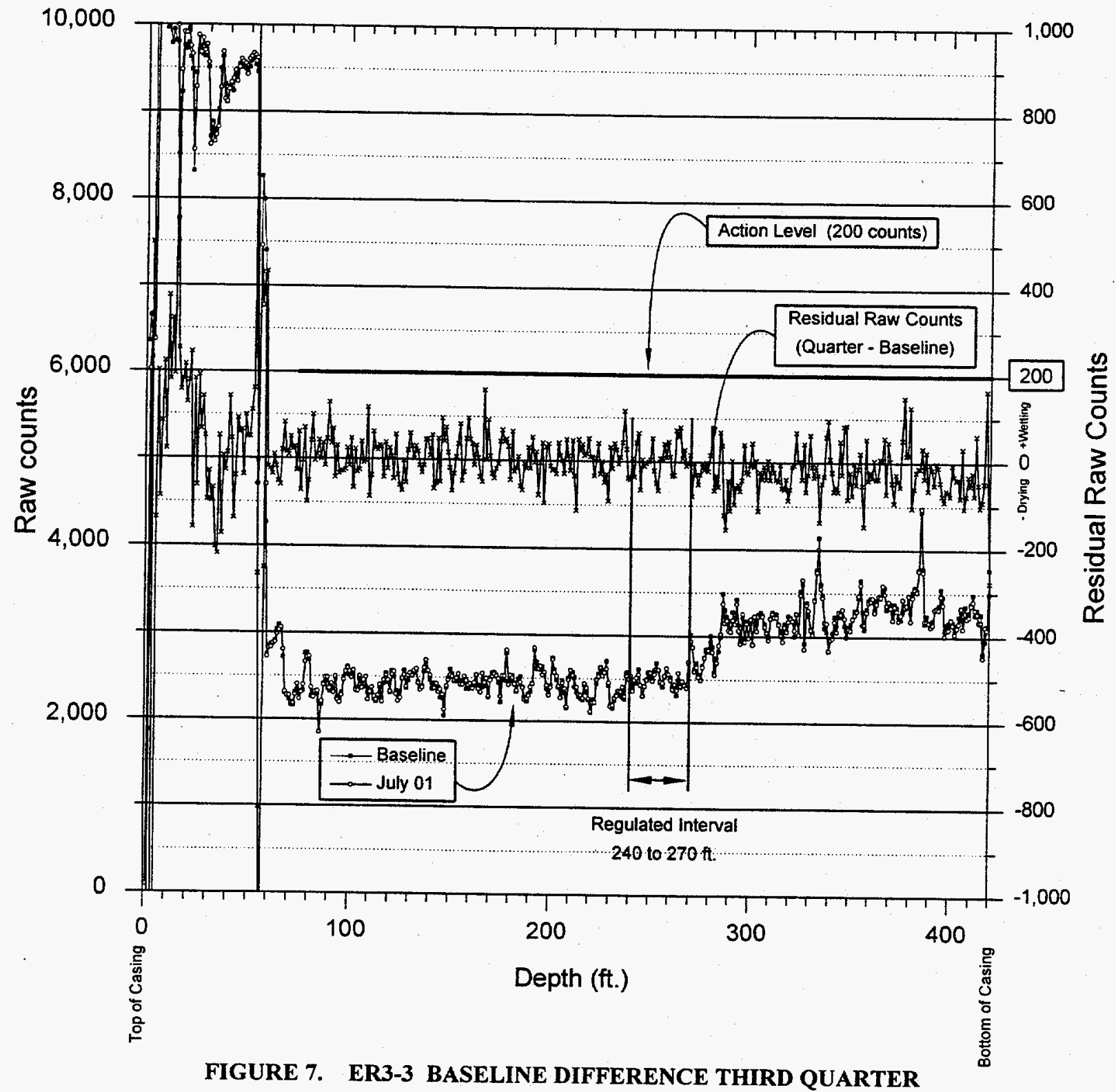


ER3-3 Soil Moisture Monitoring

Baseline Difference

October $20014^{\text {th }}$ Quarter

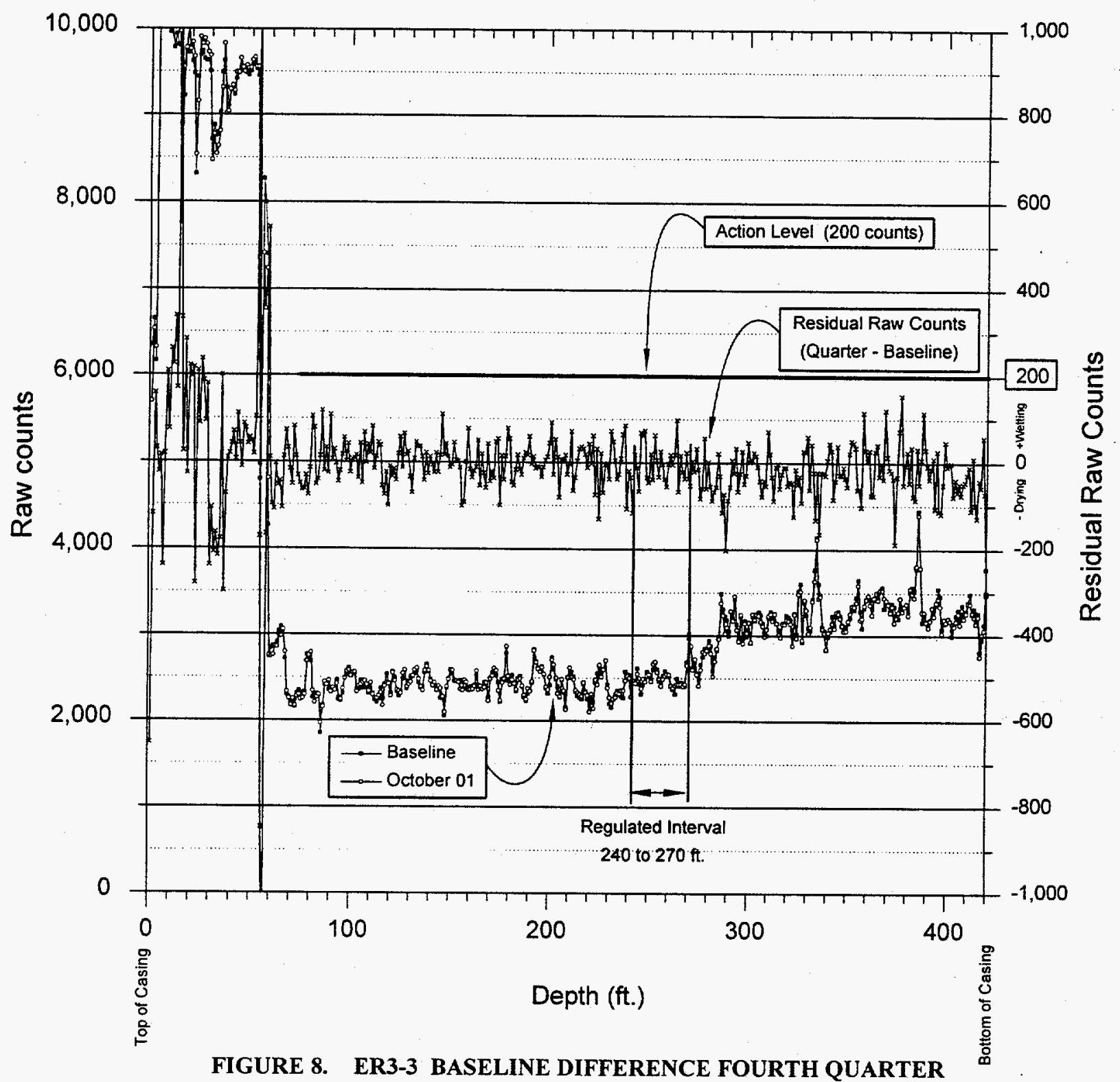


Post Closure Monitoring Report - CAU No. 91 Section: MONITORING

Revision: 0

Date: January 10. 2002

\section{THIS PAGE INTENTIONALLY LEFT BLANK}




\subsection{SUMMARY, CONCLUSIONS, AND RECOMMENDATIONS}

\subsection{SUMMARY}

- Inspections of the cover were done to identify any significant changes to the unit requiring action. No significant concerns were noted.

- The subsidence survey for the October 2000 to October 2001 monitoring period was completed in July 2001 with a monument elevation of $1230.833 \mathrm{~m}$ $(4038.166 \mathrm{ft})$ which indicated a subsidence of $-0.427 \mathrm{~cm}(-0.014 \mathrm{ft})$ relative to the baseline survey of September 1996, and an slight decrease in elevation of 0.061 $\mathrm{cm}(0.002 \mathrm{ft})$ compared to the previous year, July 2000 . While the survey results show a negative subsidence after the baseline survey, the magnitude of these changes is so small as to be at the survey instrument resolution level and it is not clear if they represent subsidence or measurement error. There is no clear evidence for any subsidence of the monument.

- Visual inspections of the concrete cover indicate no evidence of subsidence.

- The ER3-3 neutron moisture data obtained in 2001 are below the Action Level of 200 residual raw counts within the regulated interval.

\subsection{CONCLUSIONS}

- No significant concerns were observed during the site inspections over the period October 2000 through October 2001.

- There is no subsidence of the ER3-3 monument.

- The moisture content of the regulated interval between 73.2 to $82.3 \mathrm{~m}$ ( 240 to $270 \mathrm{ft}$ ) remains dry, stable and shows no signs of subsidence.

- Both the Baseline Difference and Cumulative Residual data indicate dry stable conditions for all quarterly monitoring periods. The Residual Raw Neutron Counts remain below the compliance Action Level of 200 counts within the regulated interval for period from October 2000 through October 2001.

- The closure is in compliance and performing as designed. 


\subsection{RECOMMENDATIONS}

- Although not within a compliance interval or of regulatory concern, the drying trend observed in the bentonite seal and sloughed soils beneath the cement wellhead protection plug will continue to be monitored to determine if the void area is increasing. 


\subsection{REFERENCES}

Bechtel Nevada, 1999. Organization Instruction OI-2152.103, "Environmental Restoration Neutron Moisture Logging," December 1999.

Bradley, E. and Tibshirani, R., 1993. An Introduction to the Bootstrap, Chapman \& Hall.

DOE, see U.S. Department of Energy.

DOE/NV, see U.S. Department of Energy, Nevada Operations Office.

NDEP, see Nevada Division of Environmental Protection.

Nevada Division of Environmental Protection, 1996. Letter from P. J. Liebendorfer to S. A. Mellington, "Review of Revised Technical Basis for Setting the Action Level for Subsurface Monitoring of ER3-3 (U-3fi Waste Disposal Site CAU \#91 \{Site\})," December 9, 1996.

Nevada Division of Environmental Protection, 1997, Nevada Division of Environmental Protection Permit for a Hazardous Waste Management Facility, Permit Number NEV HW009, May 1997.

Tattro, L. D., Los Alamos National Laboratory, August 4, 1989, Correspondence to Mr. Darrell M. Warren, Las Vegas, NV.

U.S. Department of Energy, 1988. Environmental Survey Preliminary Report, Nevada Test Site, Mercury, Nevada, DOE/EH/OEU-ISP, Washington, D.C.

U.S. Department of Energy, Nevada Operations Office, 1995a. Area 3 U3fi Waste Unit Resource Conservation and Recovery Act Closure Report, November 1995, Las Vegas, NV.

U.S. Department of Energy, Nevada Operations Office, 1995b. Resource Conservation and Recovery Act Industrial Site Environmental Restoration Closure Plan. Area 3 U-3fi Waste Unit, DOE/NV-404, UC-700, Las Vegas, NV.

U.S. Department of Energy, Nevada Operations Office, 1995c. Resource Conservation and Recovery Act Industrial Sites Environmental Restoration Post-Closure Plan. Area 3 U-3fi Waste Unit, DOE/NV-405, UC-700. 
U.S. Department of Energy, Nevada Operations Office, 1996. Letter from S. A. Mellington, DOE to P. J. Liebendorfer, NDEP, "Submittal of the Technical Basis for Setting the Action Level Criteria for Neutron Access Tube ER3-3, ER3-3 Baseline Data Set and Hydrologic Properties Report (CAU 91)", October 22, 1996, Las Vegas, NV.

U.S. Department of Energy, Nevada Operations Office, 1997. First Annual Report RCRA PostClosure Monitoring and Inspections for the U-3fi Waste Unit for the Period July 1995 October 1996, DOE/NV 11718-089, UC-712, Las Vegas, NV..

Waddell, R. K., 1982. Two-dimensional Steady-state Model of Groundwater Flow, Nevada Test Site and Vicinity, Nevada-California, U.S. Geologic Survey Water-Resources Investigations $82-4085,72 \mathrm{p}$.

Winograd, I. J., W. Thordarson, and R. A. Young, 1975. Hydrology of the Nevada Test Site and Vicinity, South Eastern Nevada, U.S. Department of the Interior, Geological Survey. 


\section{APPENDIX TABLE OF CONTENTS}

\section{APPENDICES}

APPENDIX A: POST-CLOSURE CARE INSPECTION CHECKLISTS

Inspection Checklist September $2001 \ldots \ldots \ldots \ldots \ldots \ldots \ldots \ldots \ldots \ldots$ A-1

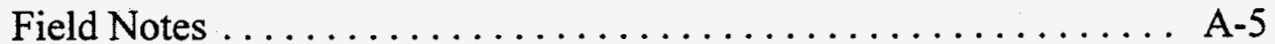

Inspection Photograph $\log \ldots \ldots \ldots \ldots \ldots \ldots \ldots \ldots \ldots \ldots \ldots \ldots$

Inspection Checklist March $2001 \ldots \ldots \ldots \ldots \ldots \ldots \ldots \ldots \ldots \ldots \ldots \ldots \ldots \ldots$

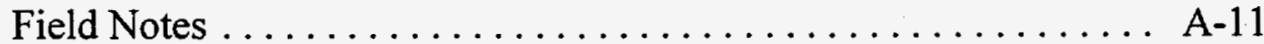

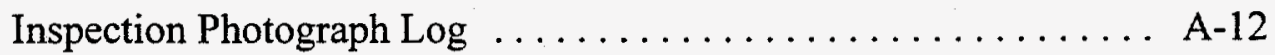

APPENDIX B: SUBSIDENCE SURVEY PLAT $\ldots \ldots \ldots \ldots \ldots \ldots \ldots \ldots \ldots$ B-1

APPENDIX C: PRECIPITATION RECORDS

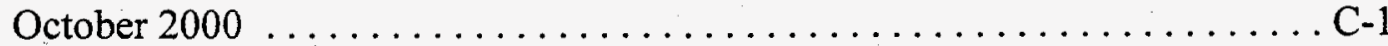

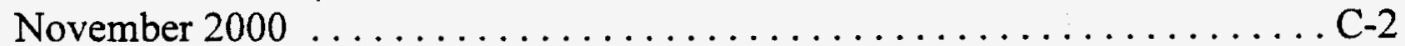

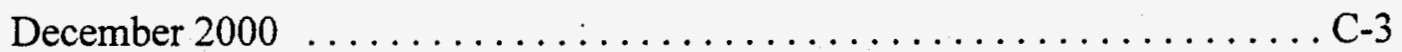

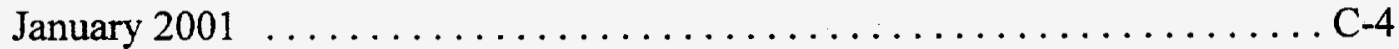

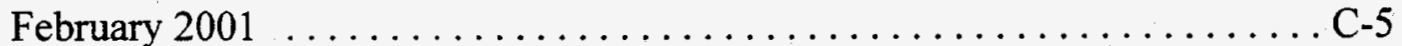

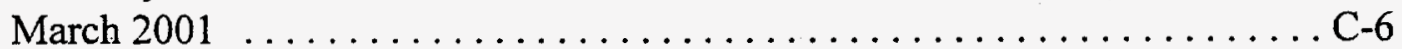

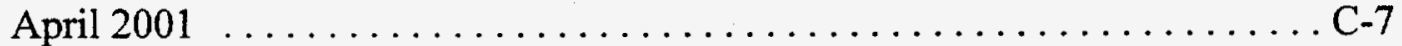

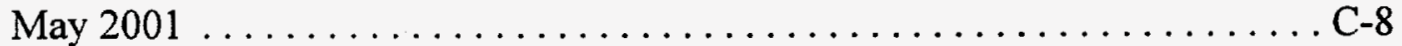

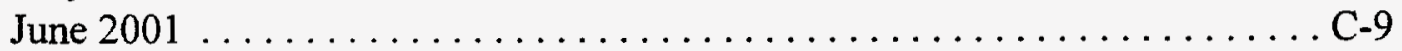

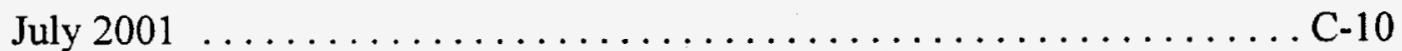

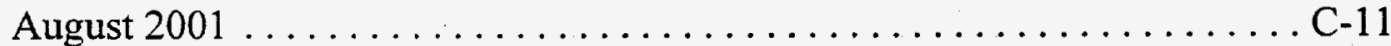

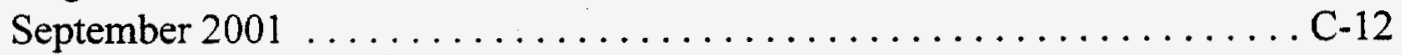

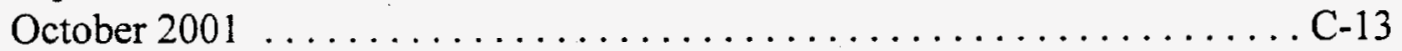

DISTRIBUTION LIST $\ldots \ldots \ldots \ldots \ldots \ldots \ldots \ldots \ldots \ldots \ldots \ldots \ldots \ldots \ldots \ldots \ldots \ldots \ldots \ldots$ 
Post Closure Monitoring Repon - CAU No. 91

Revision: 0

Date: January 10.2002

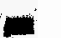

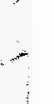

$-$

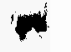

-

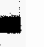

$-$

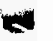

THIS PAGE INTENTIONALLY LEFT BLANK 


\section{APPENDIX A}

\section{POST-CLOSURE CARE INSPECTION CHECKLISTS}

Copies of site photographs available upon request. 
Revision: 0

Date: Januasy 10. 2002

$=$

$-$

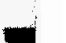

$-$

\section{THIS PAGE INTENTIONALLY LEFT BLANK}




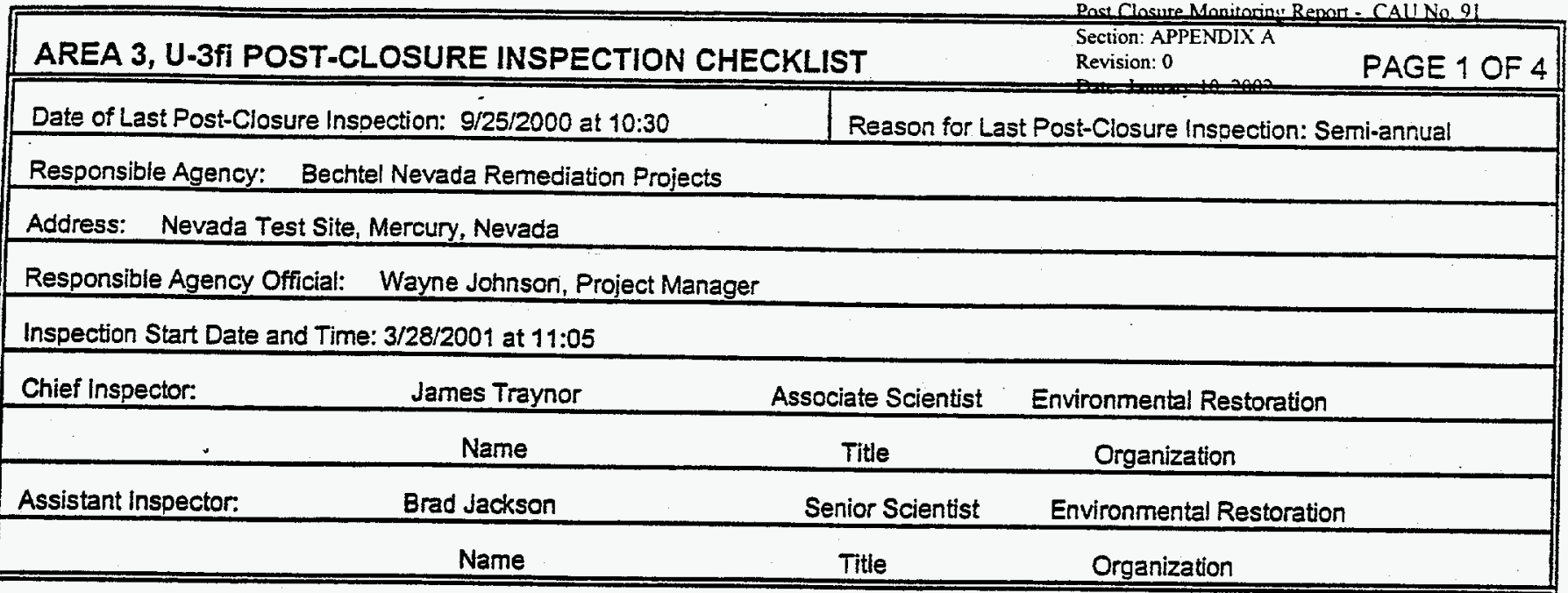

A. GENERAL INSTRUCTIONS

1. All checklist ltems must be completed and detailed comments made to document the results of the site inspection. The completed checklist is part of the field record of the inspection. Additional pages should be used as necessary to ensure that a complete record is made. Attach the additional pages and number all pages upon completion of the inspection.

2. Inspectors are to provide an up-to-date resume or vitae for inclusion in the inspection report.

3. Any checklist line item marked by an inspector in a SHADED BOX, must be fully explained or an appropriate reference to previous reports provided. The purpose of this requirement is to provide a written explanation of inspector observations and the inspector's rationale for conclusions and recommendations. Explanations are to be placed on additional attachments and crossreferenced appropriately: Explanations, in addition to narrative, will take the form of sketches, measurements, annotated site maps.

4. The site inspection is a walking inspection of the entire site (i.e., the area within 1,000 feet of U-3fi and ER-3-3), including the perimeter and sufficient transects to be able to inspect the entire surface and all features specifically described in this checklist. Every monument, site marker, sign, monitoring well access, and erosion control marker will be inspected.

5. A standard set of color $35 \mathrm{~mm}$ photographs is required. For this site, the standard set consists of 10 photographs (see instructions in Section D.6 of this checklist). In addition, all anomalous features or new features (such as changes in adjacent area land use) are to be photographed. A photo log entry will be made for each photograph taken.

6. Field notes taken to assist in completion of this checklist will become part of the inspection record. No form is specified for field notes, however, they must be legible and in sufficient detail to enable review by succeeding inspectors and the responsible agency.

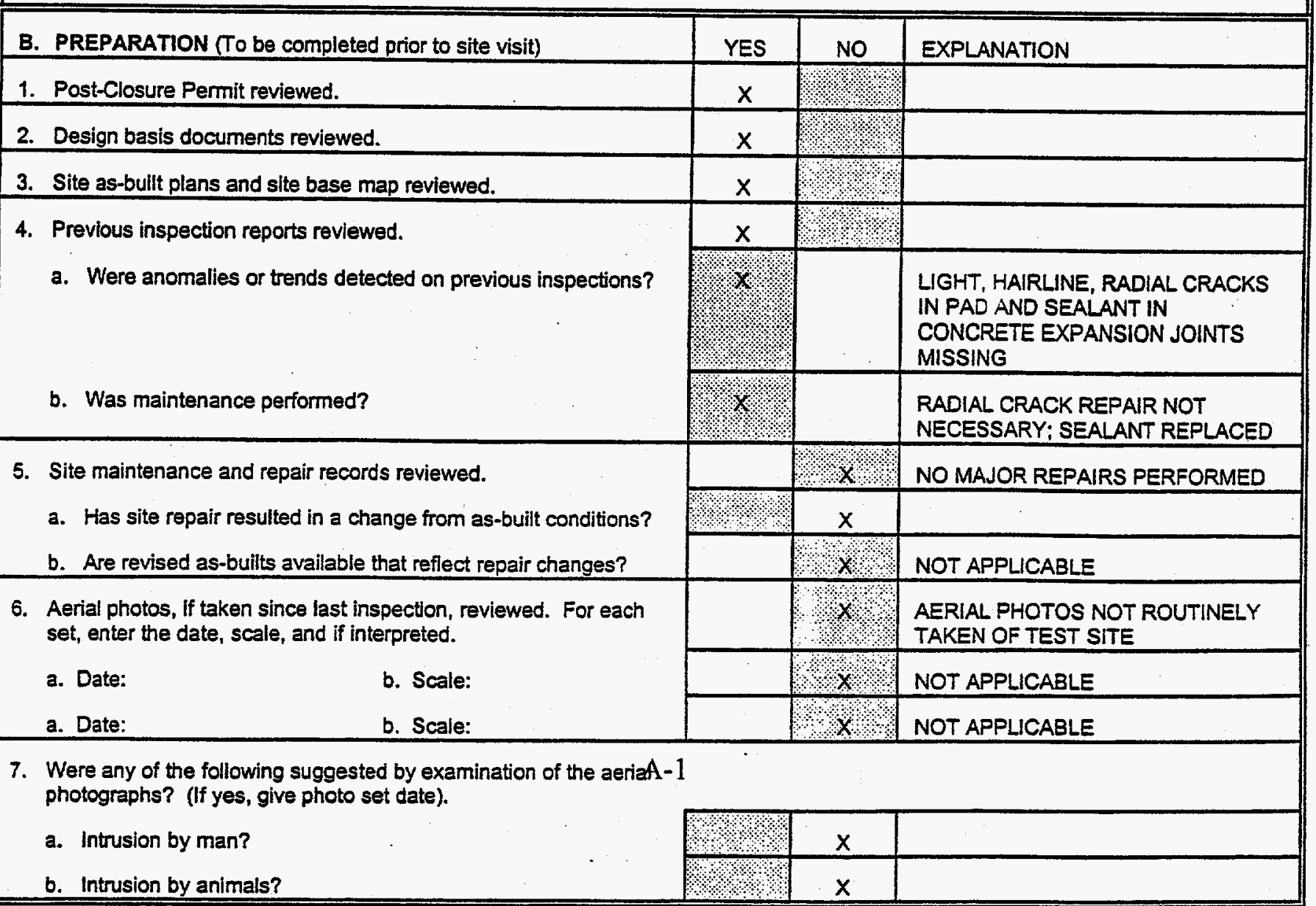




\begin{tabular}{|c|c|c|c|c|}
\hline AREA 3, U-3fI POST-CLOSURE INSPECTION CHECKLIST (cont.) & YES & NO & EVEPLOANATION & PAGE 2 OF 4 \\
\hline c. Channelized erosion in area of cover? & ॥ & $x$ & & \\
\hline d. Changes in washes in the drainage areas? & +3 & $x$ & & \\
\hline e. Faults? & 4. & $x$ & & \\
\hline f. Obstruction of diversion channel(s)? & ?. & $x$ & & \\
\hline g. Bank erosion of diversion channel(s)? & & $x$ & & \\
\hline h. Change in surrounding vegetation? & ?. & $x$ & & \\
\hline $\begin{array}{l}\text { 1. Displacement of fences, site markers, boundary markers, or } \\
\text { monuments? }\end{array}$ & & $x$ & & \\
\hline j. Change in adjacent land use? & & $x$ & & \\
\hline
\end{tabular}

\section{SITE INSPECTION PREPARATION}

Assemble the following equipment, as needed, to conduct inspections
a. Camera and film
b. Binoculars
c. Tape measure
d. Optical ranging device
e. Brunton compass
f. Photo scales
g. Erasable board
h. Keys to locks
i. Hand lens
J. Clipboard
k. Other miscellaneous support equipment

\begin{tabular}{|l|c|c|c|}
\hline D. SITE INSPECTION (TO be completed during inspection) & YES & NO & EXPLANATION \\
\hline
\end{tabular}

1. Adjacent off-site features within watershed areas upsiope of U-3fi Waste Unit.
a. Have there been any changes in use of adjacent area?
b. Are there any new roads or trails?
c. Has there been a change in the position of nearby washes?
d. Has there been lateral excursion or erosion/deposition of nearby washes?
e. Are there new drainage channels?
f. Other?

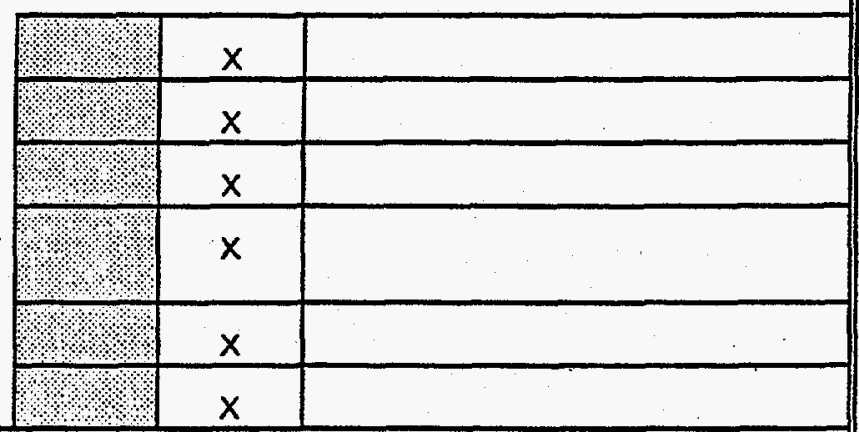

2. Access roads, fences, gates, and signs.
a. Is there a break in the fence?
b. Have any posts been damaged or their anchoring weakened?
c. Is there evidence of erosion or digging beneath the fence?
d. Does the gate show evidence of tampering or damage?
e. Is there any evidence of human intrusion?
f. Is there any evidence of large animal intrusion?
g. Have any signs been damaged or removed? (Number of signs replaced: )
h. Are access roads passable?
i. Other (Include trash and debris in or around unit)?

\begin{tabular}{|c|c|c|}
\hline \% & $x$ & \\
\hline & $x$ & \\
\hline $1 \%$ & $x$ & \\
\hline 13 & $x$ & \\
\hline \%? & $x$ & \\
\hline $1 \%$ & $x$ & \\
\hline 1.8 & & $\begin{array}{l}\text { SIGNS ARE BEGINNING TO PEEL. } \\
\text { SIGNS (4) SHOULD BE REPLACED. }\end{array}$ \\
\hline$x$ & & \\
\hline 3 & $x$ & \\
\hline
\end{tabular}


Post Closure Monitoring Repont - CAU No 91

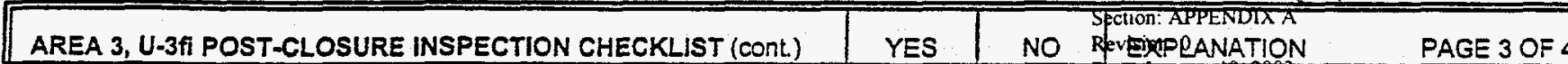

3. Monuments and other permanent features

a. Have the survey or boundary monuments been defaced or disturbed?

b. Have the site markers been disturbed by man or natural processes?

c. Do natural processes threaten to integrity of any monument or site marker?

d. Other?

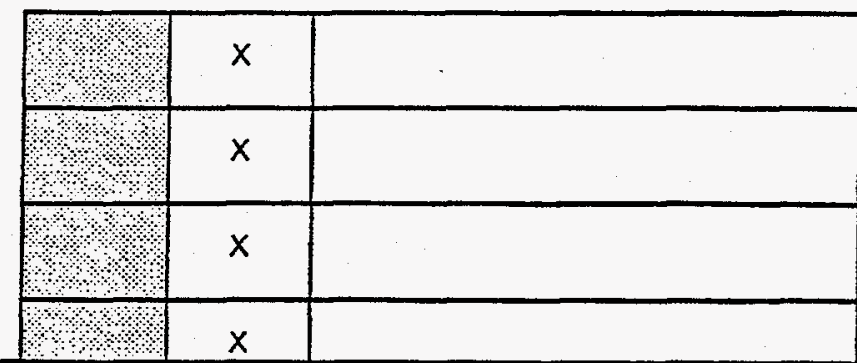

4. U-3ij Waste Unit cover
a. Is there evidence of settling?
b. Is there cracking?
c. Is there evidence of erosion around the cap (wind or water)?
d. Is there evidence of animal burrowing?
e. Other (vegetation, tresh, debris, etc. within fenced area)?

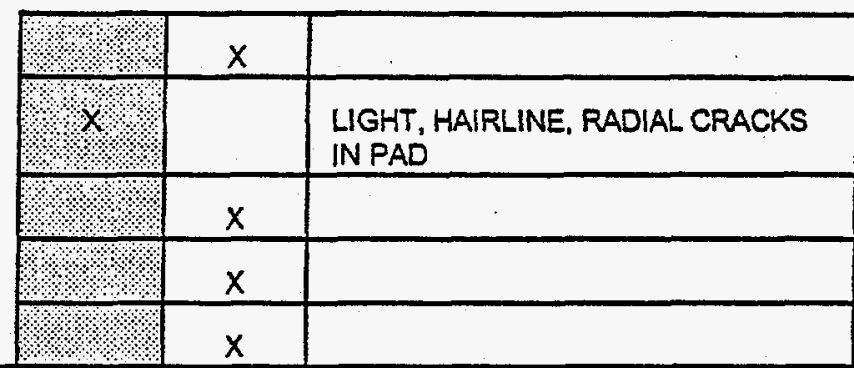

5. Site drainage features (within 1,000 feet of U-3fi).

a. Is the drainage as describe in the site plans?

b. Is there evidence of bank erosion?

c. Is there evidence of channel erosion?

d. Is there evidence of sedimentation?

e. Is there channel obstruction?

f. Is there any evidence that diversion channeis (if present) are not performing their function?

g. Other?

\begin{tabular}{|c|c|c|}
\hline$x$ & & \\
\hline & $x$ & \\
\hline & $x$ & \\
\hline & $x$ & \\
\hline & $x$ & \\
\hline & $x$ & \\
\hline $1 \%$ & $x$ & \\
\hline
\end{tabular}

6. Photo instructions

A total of 10 photographs are required to be taken during each inspection of the Area 3 U-3fi Waste Unit. Additional photos may also be taken. The required photographs shall be taken as follows:

- Four (4) from the center of the U-3fi Waste Unit cap, one in each compass direction (i.e., N, S, E, W),

- Four (4) of the U-3ii Waste Unit cap, one from each compass direction,

- Two (2) of the ER-3-3 monitoring well surface completion with compass directions noted on the photo log.

\section{Photo Documentation}

a. Have all photos required by the photo instructions been taken? (see last page of checklist)

b. Has a photo log been prepared for each roll of film exposed?

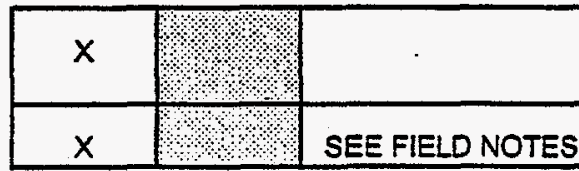

c. Number of roles exposed (1 ROLE. 10 PHOTOS)

d. Other?

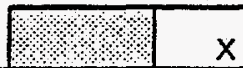

8. Monitoring well ER-3-3 access

a. Has the monitoring well access been disturbed by man or natural processes?

b. Does any natural process threaten the integrity of the monitoring well access?

c. Is the monitoring well access label plate intact and legible? A-3

d. Is the monitoring well access capped and properly secured?

\begin{tabular}{|c|c|c|}
\hline & $x$ & \\
\hline 14 . & $x$ & \\
\hline$x$ & अ & \\
\hline$x$ & ४३ & \\
\hline ४ै। & $x$ & \\
\hline
\end{tabular}




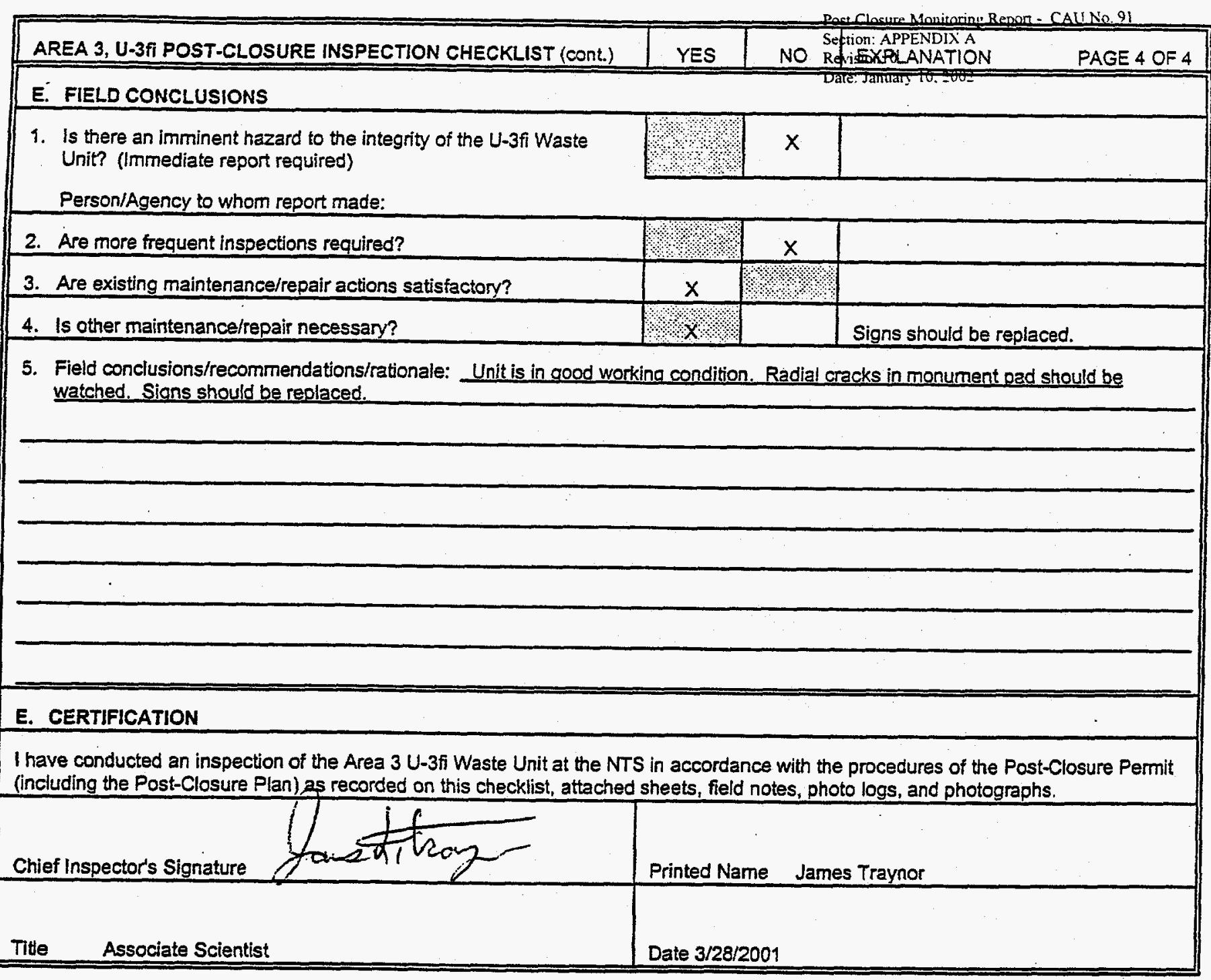


MILE

York continued from Page

Marcel 28,2001

II Safety: Wentorer o signed

Pre-Task Harl Review',

Discussed scope at work.
Marchaoc)

PROJECT NO.
BOOK N

Menders: Tracer

Bad Jackson ERT .gk Man

Ted zativatos (NDED)

47

1109 Anne onsite.

weather: Warm sunny.

Adjacent of site: None.

Fence) Gates/Signs: 4 Signs need replacing ( 2 are peeling). Fencetgates good.

Monuments: Good

Cover: Light, hairline, radial cracks in pad (woclialige)

Site drainage: Good

Photos $=1$ Inside looking north 6 Inside, we ll head looking south

2 insitulooking east 7 outside looking north

3 Inside looking south 8 outride looking east

4 Inside looking west 9 outre looking south

5 inside, weill head looking north 10 cos ide looking west

Monitoring well ER 3-3: Good

Confusions: 4 Signs need replacing

Unit in geod conditions.

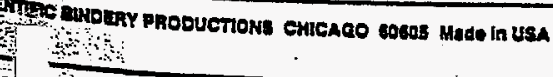

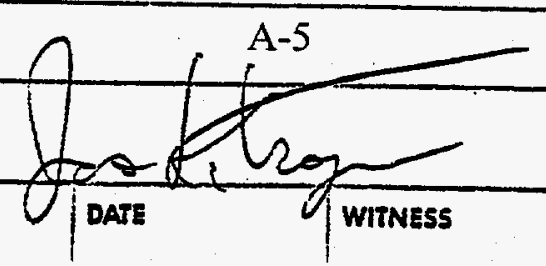

Work continued to Page

USED TO AND UNDERSTOOD BY

$\left.\right|_{\text {ont }} ^{\text {os }} 3 / 28 / 01$ 
RESOURCE CONSERVATION AND RECOVERY ACT

AREA 3 U-3FI INJECTION WELL

POST-CLOSURE SITE INSPECTION

PHOTOGRAPH LOG

\begin{tabular}{|c|c|c|}
\hline $\begin{array}{c}\text { Photo } \\
\text { Number }\end{array}$ & Date & Description \\
\hline \hline 1 & $3 / 28 / 01$ & Inside unit looking north (from center of unit) \\
\hline 2 & $3 / 28 / 01$ & Inside unit looking east \\
\hline 3 & $3 / 28 / 01$ & Inside unit looking south (from center of unit) \\
\hline 4 & $3 / 28 / 01$ & Inside unit looking west \\
\hline 5 & $3 / 28 / 01$ & Inside unit, wellhead looking north \\
\hline 6 & $3 / 28 / 01$ & Inside unit, wellhead looking south \\
\hline 7 & $3 / 28 / 01$ & Outside unit looking north \\
\hline 8 & $3 / 28 / 01$ & Outside unit looking east \\
\hline 9 & $3 / 28 / 01$ & Outside unit looking south \\
\hline 10 & $3 / 28 / 01$ & Outside unit looking west \\
\hline
\end{tabular}




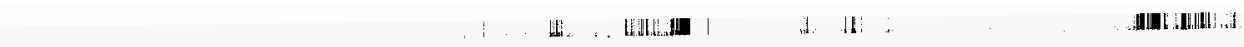

\begin{tabular}{|c|c|}
\hline Date of Lest Post-Closure Insoection: $3 / 28 / 2001$ at $11: 05$ & Reason for Last $P_{\text {Rectiog APPENDIX A }}$ A \\
\hline Responsible Agency: Eechtel Nevada Remedietion Projects & Date: January 10.2002 \\
\hline \multicolumn{2}{|l|}{ Address: Nevada Test Site. Mercury, Nevada } \\
\hline Responsibje Agency Ofilial: Wayne Johnson. Project Manager & - \\
\hline \multicolumn{2}{|l|}{ Inspection Start Date and Time: $\$ / 24 / 01$ at 13:25 } \\
\hline Chief Inspector: & Environmental Restoration \\
\hline Name & Organization \\
\hline \multicolumn{2}{|l|}{ Assistant inspector. } \\
\hline Name & Organization \\
\hline
\end{tabular}

A. GENERAL INSTRUCTIONS

1. All checklist items must be completed and detailed comments made to document the results of the site inspection. The completed checklist is part of the field record of the inspection. Additional pages should be used as necessary to ensure that a complete record is made. Attach the additional pages and number all pages upon completion of the inspection.

2. Inspectors are to provide an up-to-date resume or vitae for inclusion in the inspection report.

3. Any checklist line item marked by an inspector in a SHADED BOX, must be fully explained or an appropriate reference to previous reports provided. The purpose of this requirement is to provide a written explanation of inspector observations and the inspector's rationale for conclusions and recommendations. Explanations are to be placed on additional attachments and cross-referenced appropriately. Explanations, in addition to narrative, will take the form of sketches, measurements, annotated site maps.

4. The site inspection is a walking inspection of the entire site (i.e., the area within 1,000 feet of U-3fi and ER-3-3), including the perimeter and sufficient transects to be able to inspect the entire surface and all features specifically described in this checklist. Every monument, site marker, sign, monitoring well access, and erosion control marker will be inspected.

5. A standard set of color $35 \mathrm{~mm}$ photographs is required. For this site, the standard set consists of 10 photographs (see instructions in Section D.6 of this checklist). In addition, all anomalous features or new features (such as changes in adjacent area land use) are to be photographed. A photo log entry will be made for each photograph taker.

6. Fieid notes taken to assist in completion of this checklist will become part of the inspection record. No form is specified for field notes, however, they must be legible and in sufficient detail to enable review by succeeding inspectors and the responsible agency.

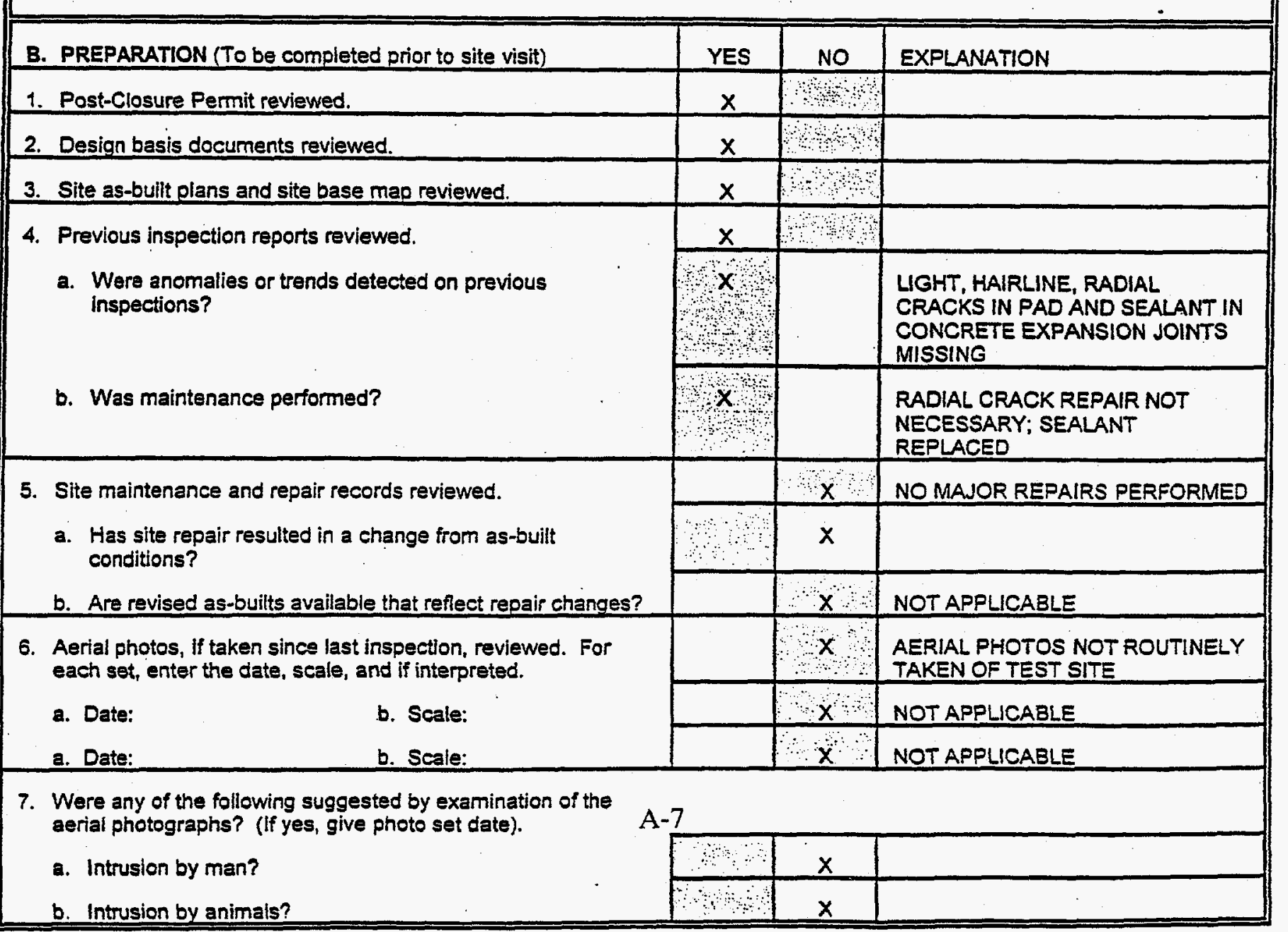




\begin{tabular}{|c|c|c|c|}
\hline AREA 3, U-3fi POST-CLOSURE INSPECTION CHECKLIST (cont.) & YES & NO & EXPLANATION \\
\hline c. Chaninelized erosion in area of cover? & $\therefore$ & $x$ & Fection: APPENDIX A \\
\hline d. Changes in washes in the drainage areas? & $\because$ & $x$ & Pate. January 10.2002 \\
\hline e. Fautts? & $\because \because$ & $x$ & \\
\hline f. Obstruction of diversion channel(s)? & a & $x$ & \\
\hline 9. Bank erosion of diversion channel(s)? & a & $x$ & \\
\hline h. Change in surrounding vegetation? & $\because \because$ & $x$ & \\
\hline $\begin{array}{l}\text { 1. Displacement of fences, site markers, boundary markers, } \\
\text { or monuments? }\end{array}$ & & $x$ & \\
\hline 1. Change in adjacent land use? & & $x$ & \\
\hline
\end{tabular}

\section{SITE INSPECTION PREPARATION}

Assemble the following equipment, as needed, to conduct inspections

a. Camera and film

b. Binoculars

c. Tape measure

d. Optical ranging device

e. Brunton compass

f. Photo scales

g. Erasable board

h. Keys to locks

i. Hand lens

j. Clipboard

k. Other miscellaneous support equipment

D. SITE INSPECTION (To be completed during inspection)

1. Adjacent off-site features within watershed areas upslope of U3i Waste Unit.

a. Have there been any changes in use of adjacent area?

b. Are there any new roads or trails?

c. Has there been a change in the position of nearby washes?

d. Has there been lateral excursion or erosion/deposition of nearby washes?

e. Are there new drainage channels?

f. Other?

\begin{tabular}{|c|c|}
\hline 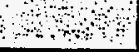 & $x$ \\
\hline+ & $x$ \\
\hline मे & $x$ \\
\hline अ्? & $x$ \\
\hline मी & $x$ \\
\hline 3 & $x$ \\
\hline
\end{tabular}

2. Access roads, fences, gates, and signs.

a. Is there a break in the fence?

b. Have any posts been damaged or their anchoring weakened?

c. is there evidence of erosion or digging beneath the fence?

d. Does the gate show evidence of tampering or damage?

e. Is there any evidence of human intrusion?

f. Is there any evidence of large animal intrusion?

g. Have any signs been damaged or removed? (Number of signs replaced:

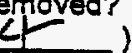

h. Are access roads passable?

1. Other (include trash and debris in or around unit)?

\begin{tabular}{|c|c|c|}
\hline 4 & $\underline{x}$ & \\
\hline अै? & $x$ & \\
\hline बा & $x$ & \\
\hline क्य & $x$ & \\
\hline +्ड & $x$ & \\
\hline 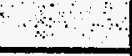 & $\underline{x}$ & \\
\hline ॥॥ & $x$ & \\
\hline$x$ & 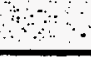 & \\
\hline म & $x$ & \\
\hline
\end{tabular}




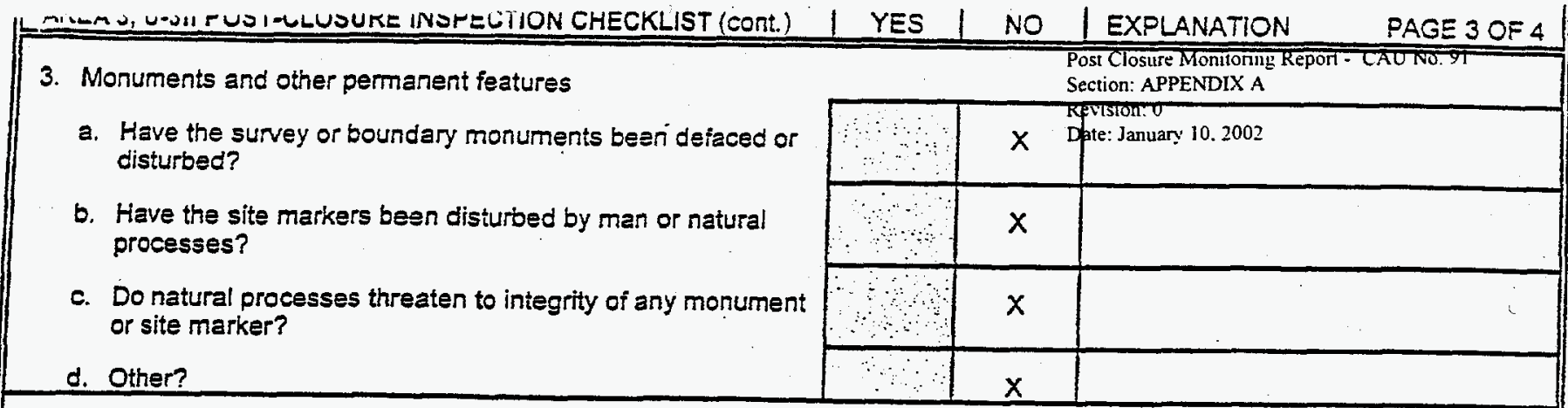

\section{U-3fi Waste Unit cover}
a. Is there evidence of settling?
b. Is there cracking?

c. Is there evidence of erosion around the cap (wind or water)?

d. Is there evidence of animal burrowing?

e. Other (vegetation, trash, debris, etc. within fenced area)?

\begin{tabular}{r|l|l|}
\hline$x$ & $x$ & \\
\hline$x$ & & $\begin{array}{l}\text { LIGHT, HAIRLINE, RADIAL } \\
\text { CRACKS IN PAD }\end{array}$ \\
\hline+3 & $x$ & \\
\hline+3 & $x$ & \\
\hline$x$ & & VEGETATION ON SOIL COVER \\
\hline
\end{tabular}

5. Site drainage features (within 1,000 feet of $U-3 f i$ ).

a. Is the drainage as describe in the site plans?

b. Is there evidence of bank erosion?

c. Is there evidence of channel erosion?

d. Is there evidence of sedimentation?

e. Is there channel obstruction?

f. Is there any evidence that diversion channels (if present) . are not performing their function?

g. Other?

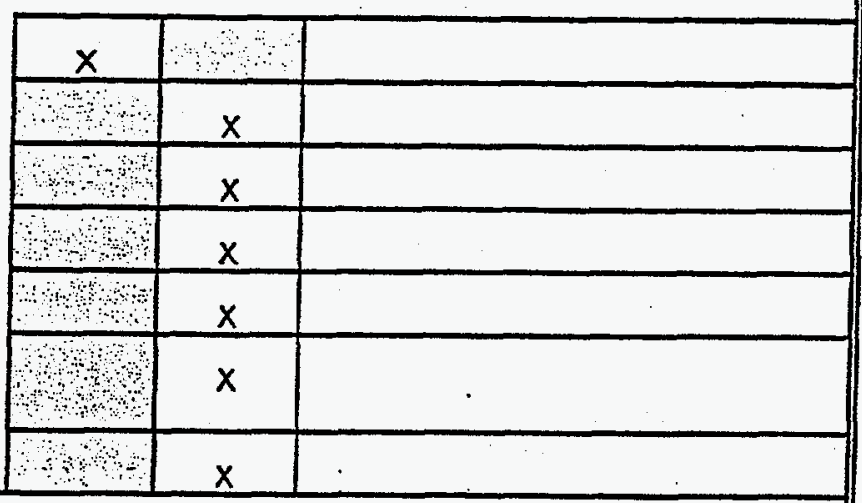

6. Photo Instructions

A total of 10 photographs are required to be taken during each inspection of the Area 3 U-3fi Waste Unit. Additional photos may also be taken. The required photographs shall be taken as follows:

- Four (4) from the center of the U-3fi Waste Unit cap, one in each compass direction (i.e., $N, S, E, W$ ),

- Four (4) of the U-3ii Waste Unit cap, one from each compass direction,

- Two (2) of the ER-3-3 monitoring well surface completion with compass directions noted on the photo log.

\section{Photo Documentation}

a. Have all photos required by the photo instructions been taken? (see last page of checklist)

b. Has a photo log been prepared for each roll of film exposed?

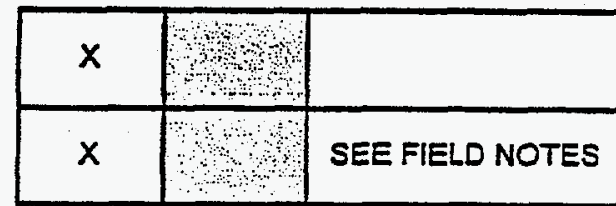

c. Number of roles exposed (1 ROLE, 10 PHOTOS)

d. Other?

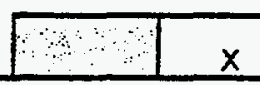

8. Monitoring well ER-3-3 access

a. Has the monitoring well access been disturbed by man or natural processes?

b. Does any natural process threaten the integrity of the monitoring well access?

c. Is the monitoring well access label plate intact and legible?

d. Is the monitoring well access capped and properiy secured?

\begin{tabular}{|r|r|l|}
\hline \hline & $x$ & \\
\hline \hline & $x$ & \\
\hline$x$ & & \\
\hline$A-9$ & $x$ & \\
\hline & & \\
\hline & $x$ & \\
\hline
\end{tabular}




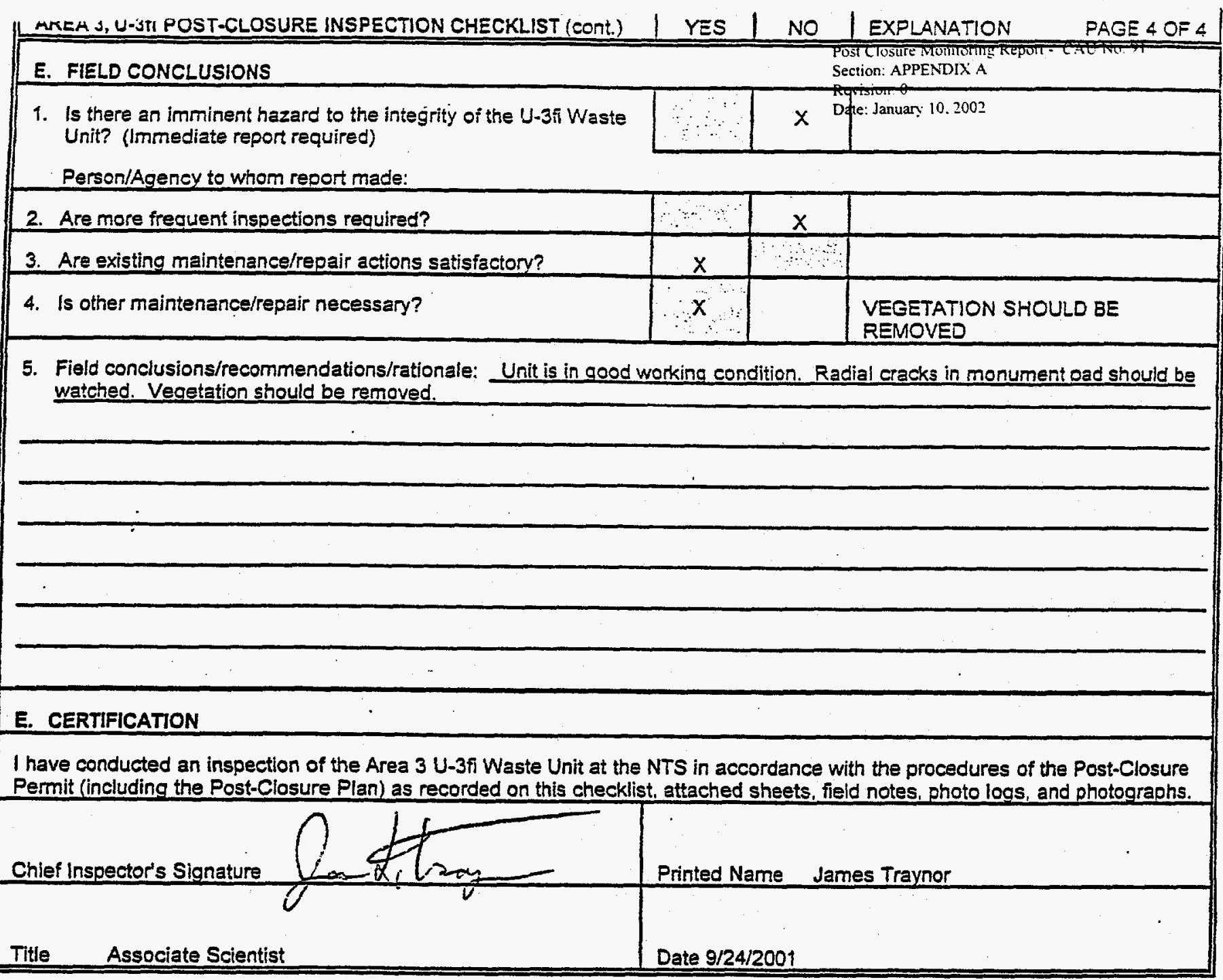


U3FC Seminal RCKA

Work continued from Page

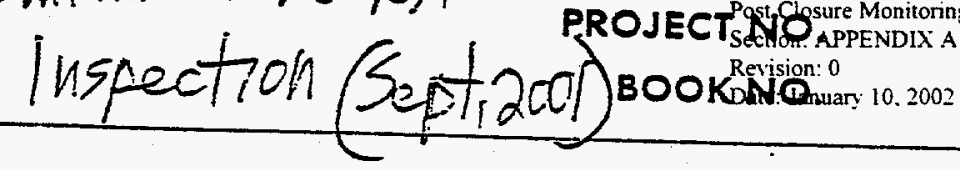

137

$9 / 24 / 01$

1325 Availed on ste.

MembersiTin Tracker

Weather: hottalm

Adjacent of ste : No change.

Roads, Fences, gates, thighs= Good, sighs rep placed.

10 Monuments! good.

Cover: light, hallie, radial cracksinped.

vegetation growing all soil cover.

Ste drainage $=$ good, nochange.

Monitoring well: good.

Photos: 1 inside uni looking north (Froncenter)

2 inside init looking east

3 inside unit looking sooth (From center)

4 inside unit looking west

5 inside unit looking north Gelled)

Conclusions/

- Recommend utzolss

Continiensuectiols

as scheduled.

Remove vegetation. inside unit looking south (wellhead) outs le whit looking south out side unit looking east ootsle uni looking sooth outsold ont looking west

ie f reno

Work continued to Page

dISCLOSED TO AND UNDER STOA RV

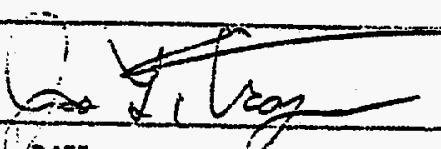

$904 / 24101$ 


\section{RESOURCE CONSERVATION AND RECOVERY ACT \\ AREA 3 U-3fi INJECTION WELL POST-CLOSURE SITE INSPECTION PHOTOGRAPH LOG}

\begin{tabular}{|c|c|c|}
\hline $\begin{array}{c}\text { Photo } \\
\text { Number }\end{array}$ & Date & \\
\hline \hline 1 & $9 / 24 / 2001$ & Inside unit looking north (from center of unit) \\
\hline 2 & $9 / 24 / 2001$ & Inside unit looking east \\
\hline 3 & $9 / 24 / 2001$ & Inside unit looking south (from center of unit) \\
\hline 4 & $9 / 24 / 2001$ & Inside unit looking west \\
\hline 5 & $9 / 24 / 2001$ & Inside unit, wellhead looking north \\
\hline 6 & $9 / 24 / 2001$ & Inside unit, wellhead looking south \\
\hline 7 & $9 / 24 / 2001$ & Outside unit looking north \\
\hline 8 & $9 / 24 / 2001$ & Outside unit looking east \\
\hline 9 & $9 / 24 / 2001$ & Outside unit looking south \\
\hline 10 & $9 / 24 / 2001$ & Outside unit looking west \\
\hline
\end{tabular}


Post Closure Monitoring Report - CAU No. 91 Section: APPENDIX B

Revision: 0

Date: January 10, 2002

\section{APPENDIX B}

\section{SUBSIDENCE SURVEY PLAT}


Post Closure Monitoring Report - CAU No. 91 Section: APPENDIX B

Revision: 0

Date: Januan 10. 2002

\section{THIS PAGE INTENTIONALLY LEFT BLANK}



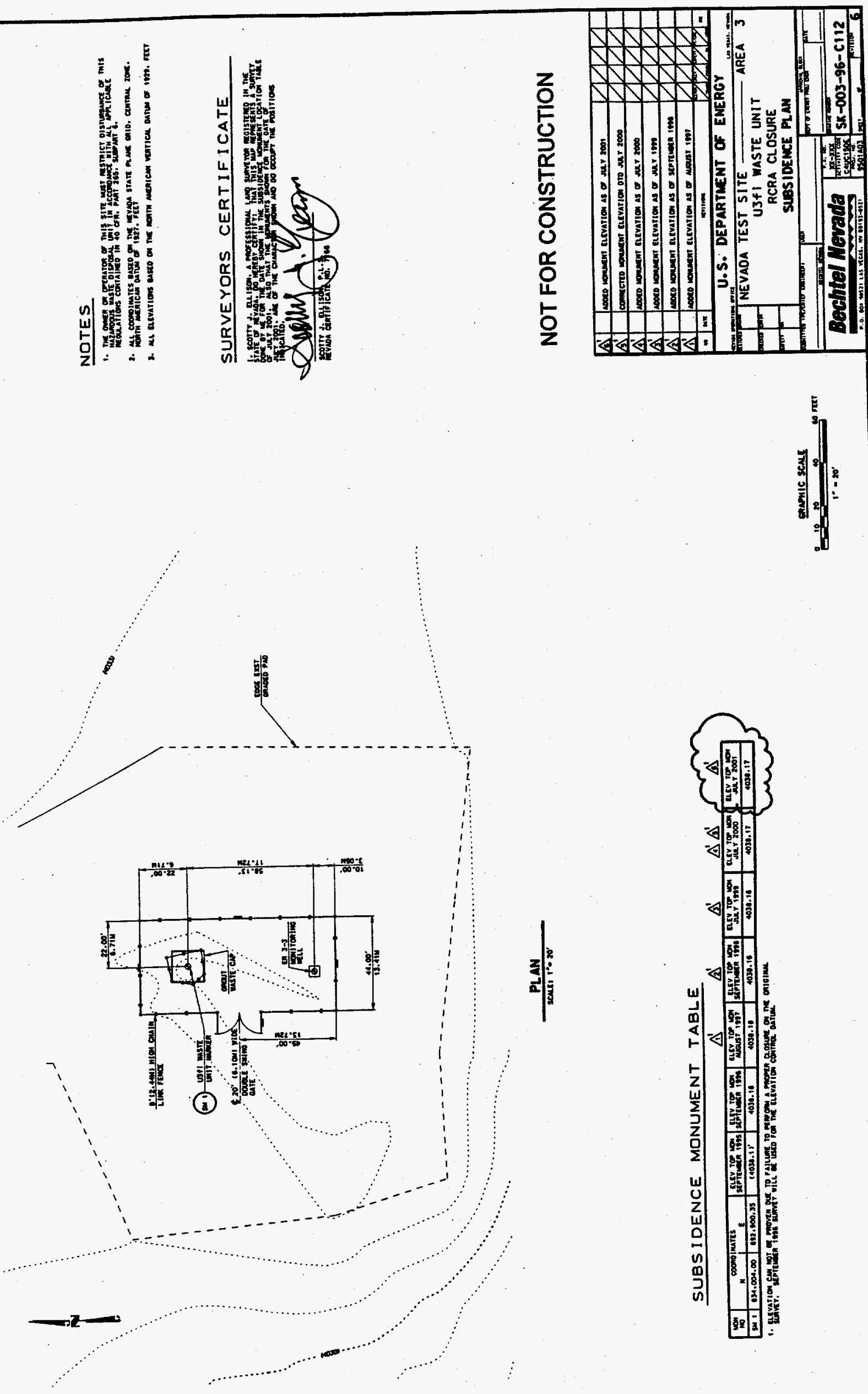
Post Closure Monitoring Report - CAU No. 91 Section: APPENDIX C

Revision: 0

Date: January 10,2002

\section{APPENDIX C}

\section{PRECIPITATION RECORDS}


Post Closure Monitoring Report - CAU No. 91 Section: APPENDIX C

Date: January 10, 2002

\section{THIS PAGE INTENTIONALLY LEFT BLANK}




\begin{tabular}{|c|c|c|c|c|c|c|c|c|c|c|c|c|c|c|c|c|c|}
\hline & & & & & & & NTSP: & RECIPI & ITATIOI & & & ection: APPE & WDIxc & & & & \\
\hline & & & & & & & & & & & & & $b_{2} 2 \sin$ & & 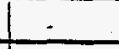 & & \\
\hline & & & & & & & & ctober 2 & 2000 & & & & & & & & \\
\hline & & & & & & & & & & & & & & & & & \\
\hline & $\mathrm{A} 12$ & BJY & CS & DRA & DAF & ETu & $4 \mathrm{JA}$ & LF2 & IMER & MV & $40 \mathrm{MI}$ & II PM1 & PHS & RV & TS2 & W5B & UCC \\
\hline 1 & & & & & & & & & & & & & & & & & \\
\hline 2 & & & & & & & & & & & & & & & & & \\
\hline 3 & & & & & & & & & & & & & & & & & \\
\hline 4 & & & & & & & & & & & & & & & & & \\
\hline 5 & & & & & & & & & & & & & & & & & \\
\hline 6 & & & & & & & & & & & & & & & & & \\
\hline 7 & & & & & & & & & & & & & & & & & \\
\hline 8 & & & & & & & & & & & & & & & & & \\
\hline 9 & & & & & & & & 0.04 & & & & 0.03 & 0.02 & & 0.02 & & \\
\hline 10 & 0.05 & & & & & & & & & & 0.04 & 0.02 & & & 0.02 & & \\
\hline 11 & & & & & & & & 0.01 & & & 0.02 & & 0.03 & & 0.01 & & \\
\hline 12 & & 0.03 & & 0.06 & 0.04 & 0.03 & & & 0.06 & 0.02 & 0.04 & & 0.25 & & 0.04 & 0.09 & 0.07 \\
\hline 513 & & & & & & & & & & & & & & & & & \\
\hline & & & & & & & & & & & & & & & & & \\
\hline 15 & & & & & & & & & & & & & & & & & \\
\hline 6 & & & & & & & & & & & & & & & & & \\
\hline .7 & & & & & & & & & & & & & & & & & \\
\hline 18 & & & & & & & & & & & & & & & & & \\
\hline 9 & & & & & & & & & & & & & & & & & \\
\hline$\angle 0$ & & & & & & & & & & & & & & & & & \\
\hline$r^{21}$ & & & & & & & & & & & & & & & & & \\
\hline 2 & 0.05 & & & & 0.02 & 0.02 & & & & 0.04 & & & 0.02 & & 0.04 & 0.01 & 0.06 \\
\hline $2 \overline{3}$ & 0.24 & 0.15 & 0.08 & 0.07 & 0.09 & 0.16 & 0.05 & 0.02 & 0.03 & 0.23 & 0.08 & 0.02 & 0.23 & 0.03 & 0.17 & 0.10 & 0.11 \\
\hline$\sqrt{4}$ & 0.02 & & & & & 0.02 & & 0.03 & & 0.01 & & & & & & & \\
\hline$[5$ & & & & & & & & & & & & & & & & & \\
\hline 26 & & & & & & & & & & & & 0.04 & & & & & \\
\hline 17 & 0.13 & & & & & 0.04 & & & & & 0.02 & 0.02 & \begin{tabular}{|l|}
0.02 \\
\end{tabular} & 0.09 & 0.02 & & \\
\hline 20 & 0.02 & & & & & 0.01 & & & & & & 0.02 & & & & & \\
\hline 29 & 0.88 & 0.18 & 0.13 & 0.13 & 0.08 & 1.08 & 0.48 & 0.25 & 0.11 & 0.55 & 0.70 & 0.54 & 0.70 & 0.04 & 0.83 & 0.09 & 0.05 \\
\hline 11 & 0.13 & 0.16 & 0.09 & 0.07 & 0.09 & 0.24 & 0.14 & 0.35 & 0.07 & 0.04 & 0.40 & 0.15 & 0.17 & 0.25 & 0.03 & 0.02 & $\begin{array}{ll}0.15 \\
\end{array}$ \\
\hline 31 & & & & & & & & & & & & & & & & & \\
\hline & & & & & & & & & & & & & & & & & \\
\hline IL & 1.52 & 0.52 & 0.30 & 0.33 & 0.32 & 1.60 & 0.67 & 0.70 & 0.27 & 0.89 & 1.30 & 0.84 & 1.44 & 0.41 & 1.18 & 0.31 & 0.44 \\
\hline & & & & & & & & & & & & & & & & & \\
\hline- & & & & $\square$ & & & & & & & & & & & & & \\
\hline 51 & ip S & tick $\mathrm{Ra}$ & in Gag & e Readi & ing: & $1.32 \mathrm{inc}$ & iches of & precipi & itation $\mathrm{f}$ & from 10 & $5103 / 00$ & to $1110^{\circ}$ & $21 / 00$. & & & & \\
\hline & & & & & & & & & & & & & & & & & \\
\hline$\frac{1}{\bar{a}} \bar{T}$ & & & & & & & & & & & & & & & & & \\
\hline$\underline{a}$ & abulate & $\mathrm{By}$ : & & $R_{2}$ & 22 & $2, Q_{2}$ & $\mathrm{~min}$ & iI) & $\angle 06 / 2$ & 2000 & & & & & & & \\
\hline$a^{k=C}$ & uality & Sontrol: & & & 00 & 2. & & & $105 / 2$ & .000 & & & & & & & \\
\hline & & & & & & & & & & & & & & & & & \\
\hline entifit & dBy: & & & & 38 & & Trest & $\frac{1}{2}$ & $1-0 \delta$ & $-200 d$ & & & & & & & \\
\hline
\end{tabular}




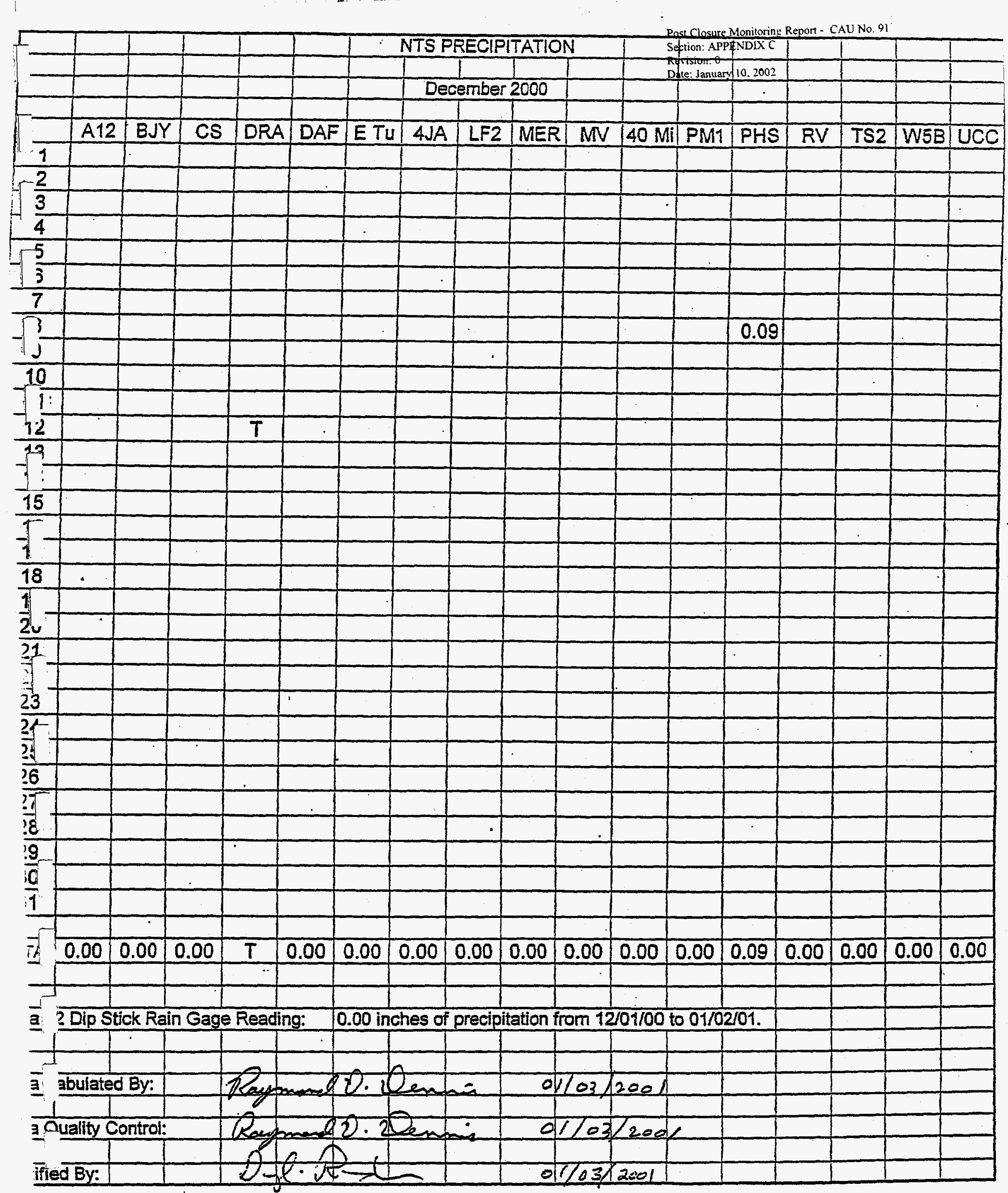




\begin{tabular}{|c|c|c|c|c|c|c|c|c|c|c|c|c|c|c|c|c|c|}
\hline & & & & & & & & \multicolumn{4}{|c|}{ NTS PRECIPITATION } & \multirow{2}{*}{\multicolumn{2}{|c|}{ 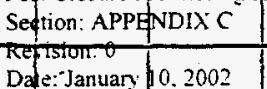 }} & & & & \\
\hline & & & & & & & & & & & & & & & & & \\
\hline & & & & & & & & \multicolumn{3}{|c|}{ January 2001} & & & & & & & \\
\hline & & & & & & & & & & & & & & & & & \\
\hline & A12 & BJY & CS & DAF & DRA & ETU & $4 \mathrm{JA}$ & $40 \mathrm{Mi}$ & LF2 & MER & MV & PM1 & PHS & RV & TS2 & W5B & IUCS \\
\hline 1 & & & & & & & & & & & & & & & & & \\
\hline 2 & & & & & & & & & & & & & & & & & - \\
\hline 3 & & & & & & & & & & & & & & & & & \\
\hline 4 & & & & & & & & & & & & & & & & & \\
\hline 5 & & & & & & & & & & & & & & & & & \\
\hline$\frac{6}{7}$ & & & & & & & & & & & & & & & $\dot{-}$ & & \\
\hline$\frac{7}{8}$ & & & & & & & & & & & & & & & & & \\
\hline$\frac{8}{0}$ & 0.35 & 0.23 & 0.27 & 0.24 & 0.34 & 0.37 & 0.44 & 0.38 & 0.30 & 0.26 & 0.45 & 0.18 & 0.30 & 0.37 & 0.36 & 0.17 & 0.30 \\
\hline 9 & 0.01 & 0.04 & 0.01 & & & 0.02 & & 0.02 & 0.05 & & & & 0.03 & & 0.03 & & 0.8 \\
\hline 10. & 0.93 & 0.01 & 0.32 & 0.32 & $T$ & 0.31 & 1.02 & 0.42 & 0.31 & & 0.83 & 0.14 & & 0.43 & 0.83 & 0.05 & 0.2 \\
\hline 11 & 0.59 & 0.98 & 1.12 & 0.68 & 0.44 & 1.27 & 0.58 & 0.99 & 0.96 & 0.42 & 0.63 & 0.27 & 1.22 & 0.89 & 0.70 & 1.07 & 1.13 \\
\hline 12 & 0.06 & & & & & & & & & & & & & & & & \\
\hline 13 & & & & & & & & & & & & & & & & & - \\
\hline 14 & & & & & & & & & & & & & & & & & \\
\hline 15 & & & & & & & & & & & & & & & & & \\
\hline 16 & & & & & & & & & & & & & & & & & \\
\hline 17 & & & & & & & & & & & & & & & & & \\
\hline 18 & & & & & & & & & & & & & & & & & \\
\hline 19 & & & & & & & & & & & & & & & 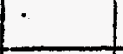 & & \\
\hline 20 & & & & & & & & & & & & & & & \pm & & \\
\hline 21 & & & & & & & & & & & & & & & & & \\
\hline 22 & & & & & & & & & & & & & & & & & \\
\hline 23 & & & & & & & & & & & & & . & & & & \\
\hline 24 & 0.31 & 0.04 & & 0.03 & 0.03 & 0.33 & & 0.11 & 0.18 & 0.02 & 0.06 & 0.27 & 0.11 & 0.04 & 0.24 & 0.06 & $0.0 \%$ \\
\hline 25 & 0.01 & 0.07 & 0.01 & & & 0.04 & 0.61 & 0.02 & 0.05 & & 0.01 & & 0.04 & & 0.02 & 0.01 & \\
\hline 26 & 0.52 & 0.15 & 0.19 & 0.26 & 0.30 & 0.57 & 0.03 & 0.07 & 0.03 & 0.19 & 0.42 & 0.08 & 0.24 & 0.42 & 0.38 & 0.20 & 0.2 \\
\hline 27 & 0.27 & 0.10 & 0.28 & & 0.06 & 0.15 & & 0.07 & 0.03 & 0.06 & 0.14 & 0.02 & 0.04 & 0.03 & 0.06 & 0.03 & 0.14 \\
\hline 28 & & & & & & & & & & & & & & & & & \\
\hline 29 & & & & & & & & & & & & & & & & & \\
\hline 30 & & & & & & & & & & & & & & & & & \\
\hline 31 & & & & & & & & & & & & & & & & & \\
\hline & & & & & & & & & & & & & & & & & \\
\hline OTAL & 3.05 & 1.62 & 2.20 & 1.53 & 1.17 & 3.06 & 2.68 & 2.08 & 1.91 & 0.95 & 2.54 & 0.96 & 1.98 & 2.18 & 2.62 & 1.59 & 2.11 \\
\hline TE & -1 & ad $A$ & neil & & oing & & & 1 & 12 and & & & & & & & & \\
\hline & & 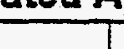 & . & & $\pi$ & 10 & ta $\mathrm{tr}$ & $\mathrm{m} \mathrm{AnI}_{2}$ & 12 and & A PMI. & & & & & & & \\
\hline 12 & Dip S & tick Rai & in Gad & $\frac{1}{e}$ & 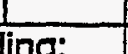 & $20 \mathrm{inn}$ & 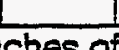 & recioit & itation f & $f$ from 01 & 102100 & 0101 to 04 & $4 / 03 / 201$ & & & & \\
\hline & & & & & & & & & & & & & & & & & \\
\hline ata $T:$ & bulate & d By: & & & & 0.2 & & & 041 & 1041 & 10 & & & & & & \\
\hline & & & & & & & & & & & & & & & & & \\
\hline ata Q & uality C & Control: & & & & 10.0 & & & 041 & YoL 1 & 101 & & & & & & \\
\hline & & & & & & & & $t$ & & & & & & & & & \\
\hline ertifie & d By: & & & 2 & 2 & $\simeq$ & D. & 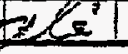 & 24 & $1=0 ; t$ & & & & & & & \\
\hline
\end{tabular}


February 2001

\begin{tabular}{|l|l|l|l|l|l|l|l|l|l|l|l|l|l|l|l}
\hline A12 & BJY & CS & DAF & DRA & E TU & 4JA & 40 MII LF2 & MER & MV & PM1 & PHS & RV & TS2 & W5B & UCC \\
\hline
\end{tabular}

$-\frac{1}{2}$

5

\begin{tabular}{|c|c|c|c|c|c|c|c|c|c|c|c|c|c|c|c|c|c|}
\hline \multirow{3}{*}{$-\frac{7}{3}$} & \multirow{2}{*}{ 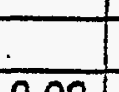 } & & & & & & & & & & & & & & & & \\
\hline & & & 0.10 & 0.04 & 0.05 & \multicolumn{2}{|r|}{0.08} & & & 0.07 & 0.03 & 0.03 & & 0.09 & & \multicolumn{2}{|l|}{0.06} \\
\hline & 0.02 & & & & $T$ & & & & & 0.02 & & & & & & & \\
\hline & & & & & & & & & & & & & & & & & \\
\hline 0 & & & & & $T$ & 0.04 & & & & & 0.02 & & 0.02 & 0.02 & & & \\
\hline 11 & 0.10 & 0.07 & 0.02 & & & 0.17 & 0.02 & 0.07 & 0.13 & & 0.07 & 0.02 & 0.10 & 0.02 & 0.04 & 0.01 & \\
\hline 12 & 0.54 & 0.82 & 0.56 & 0.58 & 0.44 & 0.96 & 0.72 & 0.52 & 0.57 & 0.46 & 0.84 & 0.22 & 0.84 & 0.60 & 0.62 & 0.41 & 0.58 \\
\hline 3 & 0.92 & 0.18 & 0.13 & 0.13 & 0.14 & 0.26 & 0.27 & 0.11 & 0.15 & 0.19 & 0.14 & 0.14 & 0.27 & 0.19 & 0.23 & 0.12 & 0.26 \\
\hline 14 & & & & & & 0.09 & & 0.02 & 0.05 & & & 0.06 & 0.04 & & 0.02 & & 0.03 \\
\hline & & & & & & & & 0.01 & 0.01 & & & & & & & & \\
\hline .5 & & & & & & & & & 0.01 & & & & & & & & . \\
\hline & & & & & & & & & & & & & & & & & \\
\hline & & & 0.03 & 0.01 & 0.01 & 0.02 & 0.05 & 0.02 & 0.02 & & 0.04 & & & 0.03 & & & \\
\hline 19 & & & & & $T$ & & & & 0.01 & & 0.02 & & & & $\cdot$ & & \\
\hline & & & & & & & & & & & & & & & 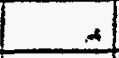 & & \\
\hline & & & & & & & & & & & & & & & & & \\
\hline & & & & & & & & & & & & & & & & & \\
\hline & & & & & & & & & & & & & & & & & \\
\hline & & 0.23 & 0.02 & 0.10 & & 0.02 & & 0.09 & 0.12 & & & & 0.10 & 0.02 & 0.14 & 0.06 & 0.09 \\
\hline 25 & 0.51 & 0.10 & 0.41 & 0.21 & 0.08 & 0.30 & 0.29 & 0.53 & 0.23 & 0.12 & 0.17 & 0.02 & 0.15 & 0.39 & 0.50 & 0.22 & 0.27 \\
\hline$\underline{z}$ & 0.15 & 0.05 & 0.23 & 0.21 & 0.39 & 0.57 & 0.04 & 0.42 & 0.12 & 0.14 & 0.62 & 0.07 & 0.30 & 0.07 & 0.34 & 0.09 & 0.23 \\
\hline 2 & 0.09 & & & 0.01 & & 0.01 & & 0.01 & & 0.01 & 0.51 & 0.02 & & & 0.09 & & 0.02 \\
\hline 28 & & & & & 0.01 & 0.01 & & & 0.01 & 0.02 & 0.02 & 0.03 & 0.02 & 0.02 & 0.01 & & \\
\hline
\end{tabular}

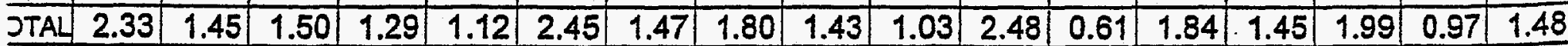

C. E: Updated April 03, 2001 to include data from A12 and PM1.

12 Dip Stick Rain Gage Reading: 6.80 inches of precipitation from 01/02/2001 to 04/03/2001

ita Tabulated By:

Roman 2.20mai 04/04101

ita Quality Control:

Reommel $D$ omin 04104101

카 ied By: 


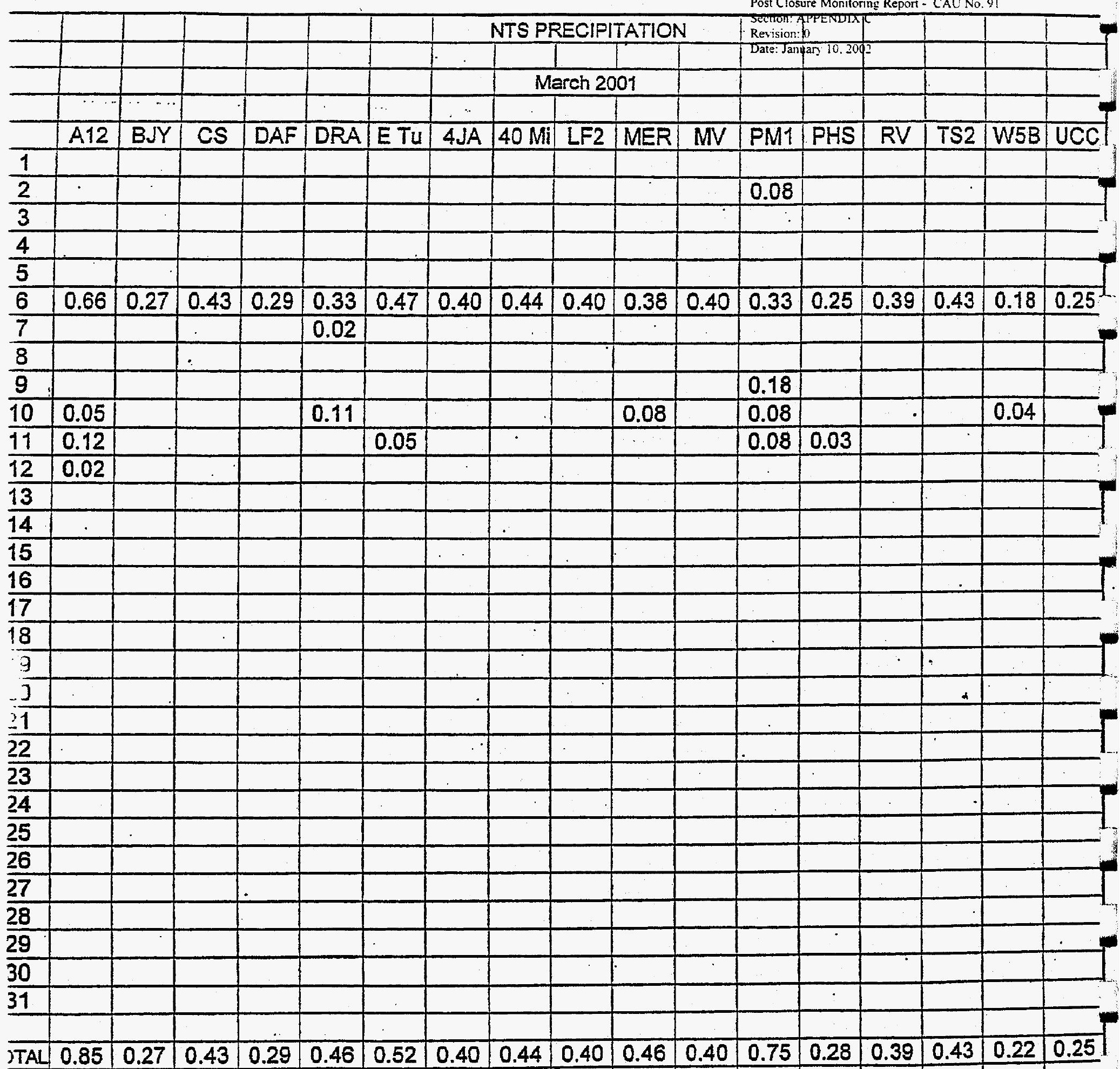

ea 12 Dip Stick Rain Gage Reading: 6.80 inches of precipitation from 01/02/2001 to 04/03/2001

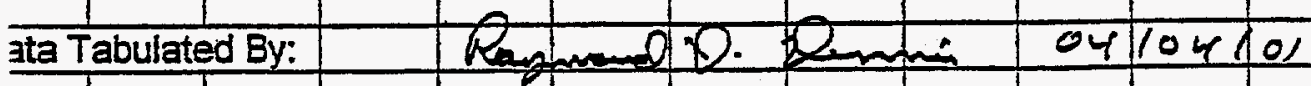
ata Quality Control: Rumed 20. Denni oullounol artified By: 
April 2001

\begin{tabular}{|l|l|l|l|l|l|l|l|l|l|l|l|l|l|l|l|l}
\hline A12 & BJY & CS & DRA & DAF & E T.U & 4JA & LF2 & MER & MV & 40 Mi & PM1 & PHS & RV & TS2 & W5B & UCC \\
\hline
\end{tabular}

\begin{tabular}{|c|c|c|c|c|c|c|c|c|c|c|c|c|c|c|c|c|c|c|c|}
\hline \multirow{2}{*}{\multicolumn{18}{|c|}{$\frac{1}{2}$}} & & \\
\hline & & & & & & & & & & & & & & & & & & & \\
\hline \multicolumn{18}{|l|}{3} & & \\
\hline 4 & & & & & & 0.01 & & & & & & & & & & & & & \\
\hline 5 & 0.22 & & 0.02 & 0.01 & 0.03 & 0.13 & 0.03 & 0.10 & & & 0.09 & 0.29 & 0.06 & 0.02 & 0.07 & 0.01 & 0.04 & & \\
\hline 6 & & 0.02 & & & & & & 0.05 & & & 0.02 & & & 0.02 & & 0.02 & 0.01 & & \\
\hline 7 & 0.52 & 0.14 & 0.07 & 0.01 & 0.14 & 0.60 & 0.02 & 0.28 & 0.01 & 0.40 & 0.40 & 0.14 & 0.22 & & 0.35 & 0.03 & 0.06 & & \\
\hline 8 & & & & & & & & 0.05 & & & 0.02 & & & & & & & & \\
\hline \multicolumn{18}{|l|}{9.} & & \\
\hline 10 & & & & 0.02 & & 0.02 & & & 0.02 & & 0.02 & 0.05 & 0.01 & & & & & & \\
\hline 11 & 0.02 & 0.05 & 0.18 & 0.06 & 0.35 & 0.05 & 0.05 & & 0.08 & 0.28 & 0.04 & 0.20 & 0.05 & 0.05 & 0.15 & 0.01 & 0.35 & & \\
\hline 12 & 0.08 & 0.02 & & & & & & 0.04 & & & 0.01 & & & & & 0.17 & 0.02 & & \\
\hline 13 & & & & - & & & & & & & & & & & & & & & \\
\hline \multicolumn{18}{|l|}{14} & & \\
\hline \multirow{2}{*}{\multicolumn{18}{|c|}{5}} & & \\
\hline & & & & & & & & & & & & & & & & & & & \\
\hline \multicolumn{18}{|l|}{7} & & \\
\hline \multicolumn{18}{|l|}{8} & & \\
\hline 19 & 0.10 & & & & & 0.10 & & 0.02 & & 0.07 & & 0.19 & & & 0.12 & & & & \\
\hline 0 & 0.10 & . & 0.06 & 0.02 & & 0.22 & 0.16 & 0.20 & 0.02 & 0.09 & 0.14 & 0.03 & 0.01 & 0.29 & 0.23 & & 0.02 & & \\
\hline$\leqslant 1$ & 0.21 & & & $\mathrm{~T}$ & 0.02 & 0.08 & & 0.08 & & & 0.19 & 0.16 & 0.02 & & 0.02 & & & & \\
\hline 22 & & & & & & & & & & & & & & & & & & & \\
\hline \multicolumn{18}{|l|}{3} & & \\
\hline \multicolumn{18}{|l|}{24} & & \\
\hline 5 & & & & & & & & & & & & & & & & & & & \\
\hline \multirow{2}{*}{\multicolumn{19}{|c|}{27}} & \\
\hline & & & & & & & & & & & & & & & & & & & \\
\hline \multicolumn{20}{|l|}{3} \\
\hline \multirow{2}{*}{\multicolumn{20}{|c|}{3}} \\
\hline & & & & & & & & & & & & & & & & & & & \\
\hline & & & & & & & & & & & & & & & & & & & \\
\hline & & & & & & & & & & & & & & & & & & & \\
\hline \multicolumn{20}{|c|}{1.21} \\
\hline
\end{tabular}

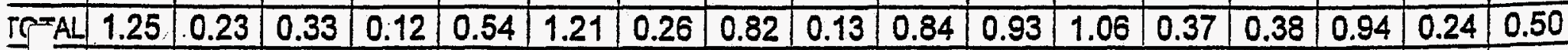
412 Dip Stick Rain Gage Reading: 1.10 inches of precipitation from $04 / 03 / 2000$ to $05 / 01 / 2000$.

כ.

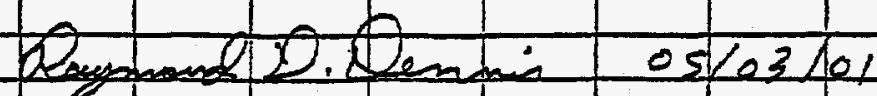
Jata Quality Control:

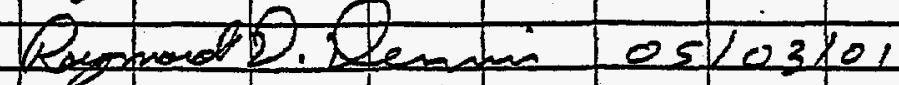
Se ified By: $05+23-41$ 


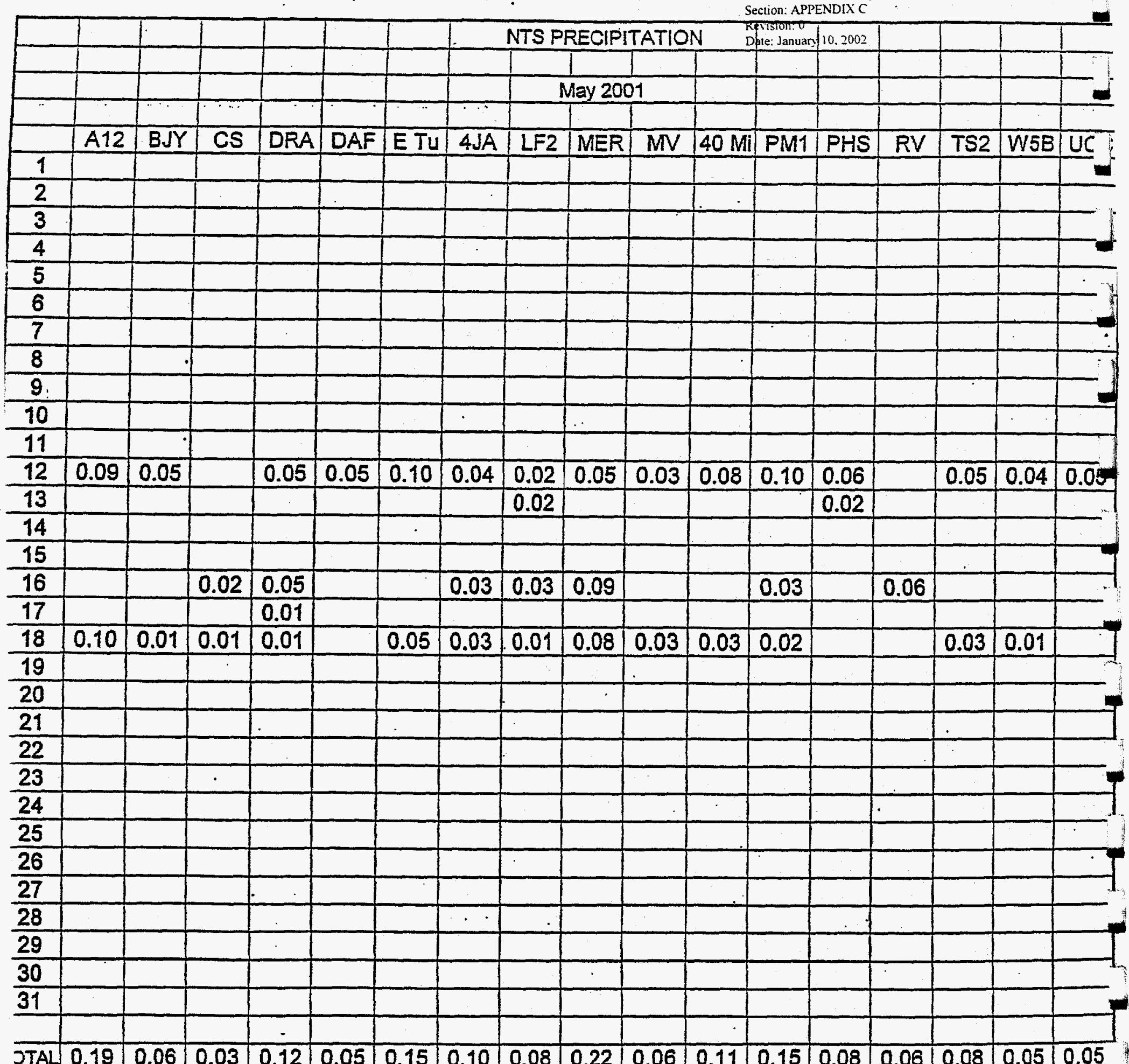

\begin{tabular}{lllllllllllll|l|l|l|l|l|l|l|}
\hline JTAL & 0.19 & 0.06 & 0.03 & 0.12 & 0.05 & 0.15 & 0.10 & 0.08 & 0.22 & 0.06 & 0.11 & 0.15 & 0.08 & 0.06 & 0.08 & 0.05 & 0.05 \\
\hline
\end{tabular}

rea 12 Dip Stick Rain Gage Reading:
0.20 inches of precipitation from 05/01/01 to 06/01/01.

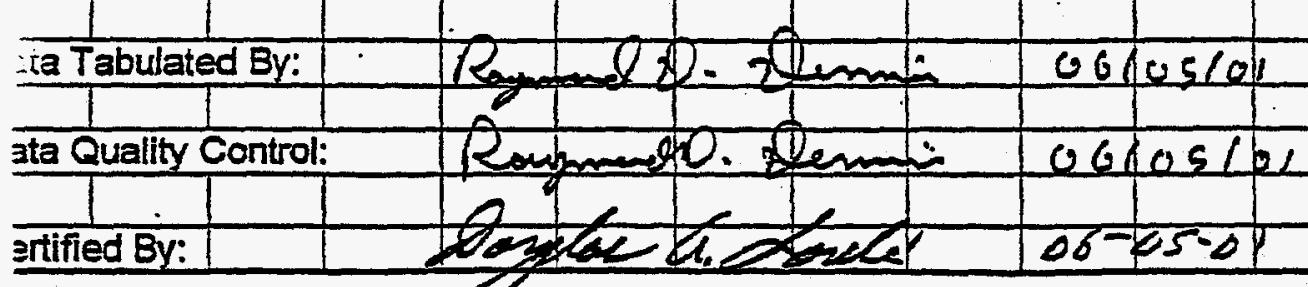


Post Closure Monitoring Repon - CAU No. 91

NTS PRECIPITATION

Retision: 0

June 2001

\begin{tabular}{|l|l|l|l|l|l|l|l|l|l|l|l|l|l|l|l|l|l|l}
\hline & A12 & BJY & CS & DRA & DAF & E TU & 4JA & LF2 & MER & MV & 40 Mi & PM1 & PHS & RV & TS2 & W5B & UCC \\
\hline 1 & & &
\end{tabular}

$\frac{1}{2}$

3

$-4$

5 .

6

7

8

$-\frac{9}{10}$

11

$-12$

$1 \frac{3}{14}$

$-\frac{5}{6}$

17

$-\frac{8}{9}$

20

1

22

3

3

$-1$

28

3

30

$5^{3 x}$

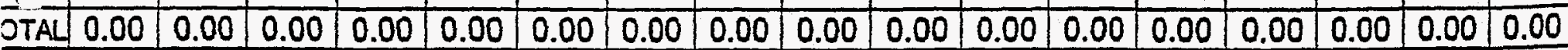

rea 12 Dip Stick Rain Gage Reading:

0.00 inches of precipitation from $06 / 01 / 00$ to $07 / 03 / 00$.

$-7$

ata Tabulated By:

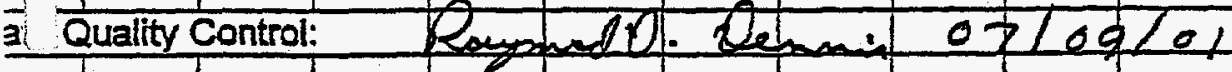

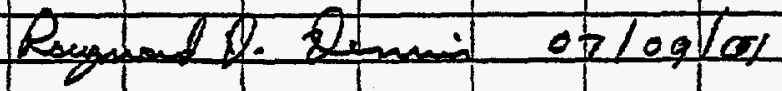

ied By:

The Reding: 


\begin{tabular}{|c|c|c|c|c|c|c|c|c|c|c|c|c|c|c|c|c|c|}
\hline & & & & & & \multicolumn{5}{|c|}{ NTS PRECIPITATION } & \multicolumn{3}{|c|}{ 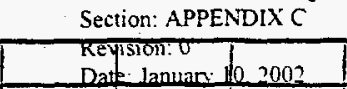 } & \multicolumn{4}{|r|}{ 프 } \\
\hline & & & & & & & & & & & & & & & & & \\
\hline & & & & & & & & July 200 & & & & & & & & & \\
\hline & & 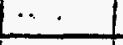 & & & & & & & & & & & & & & & \\
\hline & A12 & BJY & CS & DRA & DAF & ETu & $4 \mathrm{JA}$ & LF2 & MER & MV & $40 \mathrm{Mi}$ & PM1 & PHS & RV & TS2 & W5B & 14 \\
\hline 1 & & & & & & & & & & & & & & & & & \\
\hline 2 & 0.13 & 0.01 & 0.01 & 0.01 & 0.03 & 0.12 & 0.04 & & 0.03 & & & & 0.02 & & & & \\
\hline 3. & 0.12 & 0.03 & & $T$ & & 0.06 & 0.01 & & 0.01 & 0.02 & 0.01 & 0.02 & 0.01 & 0.01 & 0.01 & & \\
\hline 4 & 0.02 & 0.02 & 0.60 & 0.10 & 0.01 & 0.01 & 0.02 & 0.08 & 0.17 & 0.15 & 0.07 & 0.14 & & 0.17 & 0.01 & 0.15 & 프 \\
\hline 5 & 0.42 & 0.04 & & 0.09 & & 0.20 & 0.02 & 0.09 & & 0.01 & 0.02 & 0.29 & 0.10 & 0.02 & & 0.02 & 0.0 \\
\hline 6 & 0.22 & 0.05 & 0.05 & 0.10 & 0.03 & & 0.57 & 0.25 & 0.15 & 0.05 & 0.28 & 0.66 & 0.11 & 0.32 & 0.02 & 0.07 & \\
\hline 7 & & & & 0.02 & & & 0.03 & 0.10 & 0.25 & 0.02 & 0.02 & 0.10 & & 0.02 & & & \\
\hline 8 & & & & & & & & 0.32 & 0.02 & & & 0.08 & 0.02 & & & & \\
\hline 9 & & 0.02 & & & 0.02 & 0.20 & 0.02 & 0.01 & 0.02 & 0.28 & & 0.03 & 0.02 & & & 0.03 & 0. \\
\hline 10 & & & & & & & & & & & & 0.02 & & & & & \\
\hline 11 & & & & & & & & & & & & & & & & & \\
\hline 12 & & & & & & & & & & & & & & & & & 0 \\
\hline 13 & & & & & & & & & & & & & & & & & \\
\hline 14 & & & & & & & & & & & & & & & & & \\
\hline 15 & & & & & & & & & & & & & & & & & $=$ \\
\hline 16 & & & & & & & & & & & & & & & & & \\
\hline 17 & & & & & & & & & & & & & & & & & \\
\hline 18 & & & & & & & & & & & & & & & & & \\
\hline 19 & & & & & & & & & & & & & & & & & \\
\hline 20 & & & & & & & & & & & & & & & & & \\
\hline 21 & & & & & & & & & & & & & & & & & \\
\hline 22 & & & & & & & & & & & & & & & & & \\
\hline 23 & & & & & & & & & & & & & & & & & \\
\hline 24 & & & & & & & & & & & & & & & & & \\
\hline 25 & & & & & & & & & & & & & & & & & \\
\hline 26 & & & & & & & & & & & & & & & & & \\
\hline 27 & & & & & & & & & & & & & & & & & \\
\hline 28 & & & & & & & & & & & & & & & & & \\
\hline 29 & & & & & & & & & & & & & & & & & \\
\hline 30 & & & & & & & & & & & & & & & & & \\
\hline 31 & & & & & & & & & & & & & & & & & \\
\hline & & & & & & & & & & & & & & & & & \\
\hline TOTAL & 0.91 & 0.17 & 0.66 & 0.32 & 0.09 & 0.59 & 0.71 & 0.85 & 0.65 & 0.53 & 0.40 & 1.34 & 0.28 & 0.54 & 0.04 & 0.27 & 0.34 \\
\hline & & & & & & & & & & & & & & & & & \\
\hline & & & 5 & & 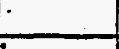 & & & & & & & & & & & & \\
\hline Area 1 & Dips & tick Ra & in $\mathrm{Gag}$ & e Read & ing: & $0.40 \mathrm{ing}$ & iches of & f precipi & itation & from 0 & $7 / 03 / 00$ & to $08 / 0$ & $1 / 00$. & & & & \\
\hline & & & & & & & & & & & & & & & & & \\
\hline & abulate & & $R$ & & 0.6 & & & 88702 & 101 & & & & & & & & \\
\hline & & & & & & & & & & & & & & & & & \\
\hline Jata C & uality & Control: & Ex & $d$ & $x-2$ & Eem & & 88102 & 201 & & & & & & & & \\
\hline & & & 21 & & & & & & & & & & & & & & \\
\hline & $y$. & & & & & & & $98-22$ & -01 & & & & & & & & \\
\hline
\end{tabular}




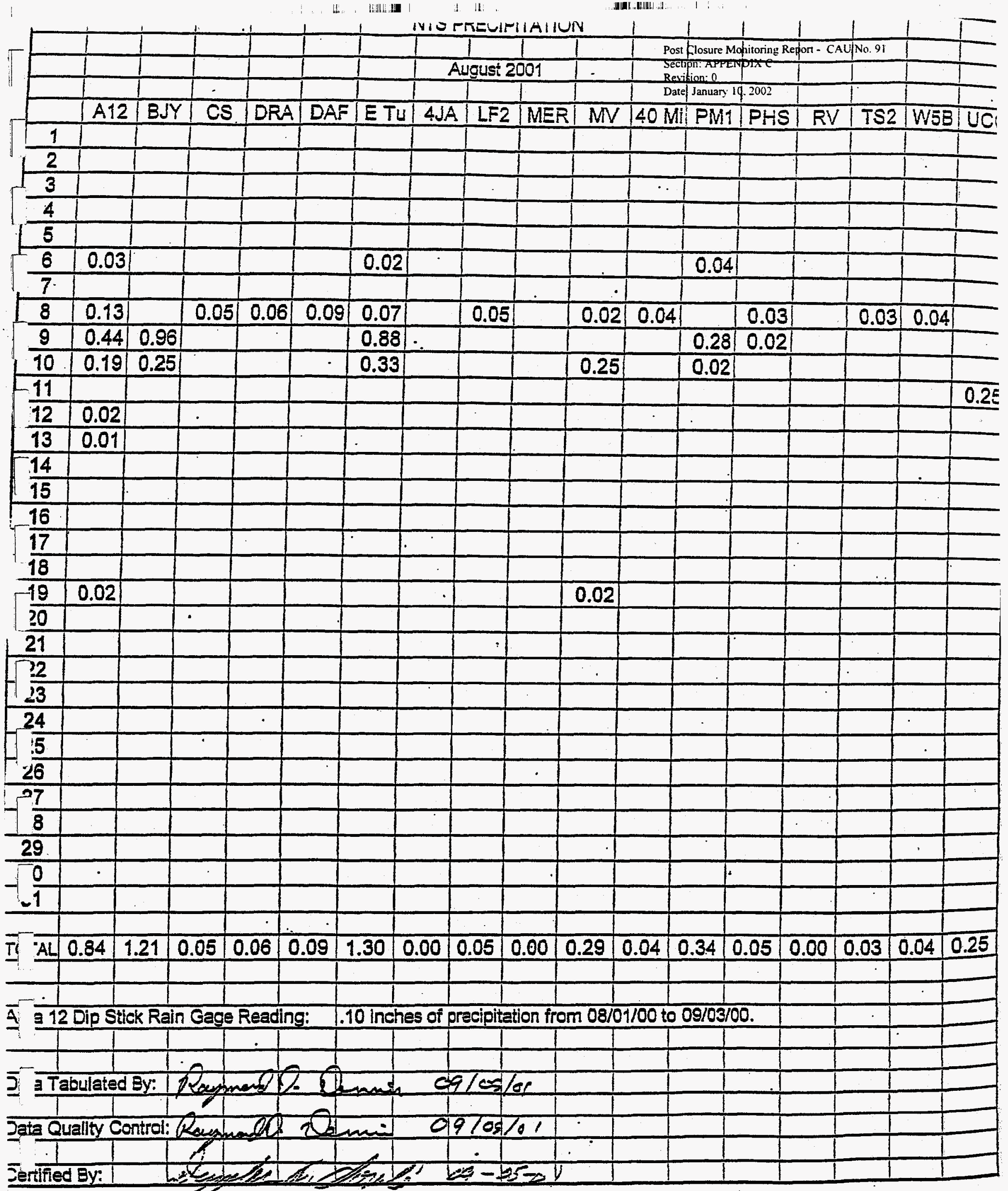




\begin{tabular}{|c|c|c|c|c|c|c|c|c|c|c|c|c|c|c|c|c|c|}
\hline & & & & & & \multicolumn{5}{|c|}{ NTS PRECIPITATION } & \multicolumn{5}{|c|}{ 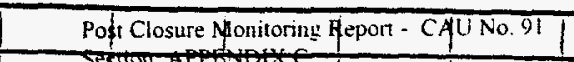 } & & \\
\hline & & & & & & & & & & & & ision: 0 & & & & & 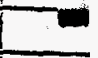 \\
\hline & & & & & & & Sept & ember & 2001 & & & ene January | & 40.2002 & & & & \\
\hline & & & & & & & & & & & & & & & & & \\
\hline & A12 & BJY & CS & DRA & DAF & ETU & $4 \mathrm{JA}$ & LF2 & MER & MV & $40 \mathrm{Mi}$ & PM1 & PHS & $R V$ & TS2 & W5E & $\overline{U Q d}$ \\
\hline 1 & & & & & & & & & & & & & & & & & 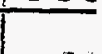 \\
\hline 2 & & & & & & & & & & & & & & & & & 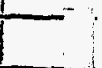 \\
\hline 3 & 0.45 & 0.16 & 0.11 & 0.07 & 0.07 & 0.30 & 0.94 & 1.20 & 0.04 & 0.46 & 1.33 & 0.69 & 0.30 & 0.18 & 0.33 & 0.09 & 0.7 \\
\hline 4 & & & & & & & & 0.02 & & & & & & & & & \\
\hline 5 & & & & & & & & & & & & & & & & & \\
\hline 6 & & & & & & & & & & & & & & & & & \\
\hline 7 & & & & & & & & & & & & & & & & & \\
\hline 8 & & & & & & & & & & & & & & & & & \\
\hline 9 & & & & & & & & & & & & & & & & & 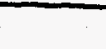 \\
\hline 10 & & & & & & & & & & & & & & & & & \\
\hline 11 & & & & & & & & & & & & & & & & & \\
\hline 12 & 0.07 & 0.06 & 0.02 & 0.01 & 0.04 & 0.10 & 0.02 & 0.02 & 0.02 & 0.03 & & & 0.10 & 0.08 & 0.15 & 0.05 & 0.07 \\
\hline 13 & & & & & & & & & . & & & & & & & & \\
\hline 14 & & & & & & & & & & & & & & & & & \\
\hline 15 & & & & & & & & & & & & & & & & & \\
\hline 16 & & & & & & & & & & & & & & & & & \\
\hline 17 & & & & & & & & & & & & & & & & & \\
\hline 18 & & & & & & & & & & & & & & & & & \\
\hline 19 & & & $\dot{-}$ & & & & & & & & & & & & & & \\
\hline 20 & & & & & & & & & & & & & & & & & \\
\hline 21 & & & & & & & & & & & & & & & & & \\
\hline 22 & & & & & & & & & & & & & & & & & \\
\hline 23 & & & & & & & & & & & & & & & & & \\
\hline 24 & & & & & & & & & & & & & & & & & \\
\hline 25 & & & & & & & & & & & & & & & & & \\
\hline 26 & & & & & & & & & & & & & & & & & \\
\hline 27 & & & & & & & & & & & & & & & & & \\
\hline 28 & & & & & & & & & & & & & & & & & \\
\hline 29 & & & & & & & & & & & & 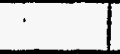 & & & & & \\
\hline 30 & & & & & & & & & & & & & & & & & \\
\hline 31 & & & & & & & & & & & & & & & & & \\
\hline
\end{tabular}

\section{\begin{tabular}{lllllllllllll|l|l|l|l|l|l|l}
\hline OTAL & 0.52 & 0.22 & 0.13 & 0.08 & 0.11 & 0.40 & 0.96 & 1.24 & 0.06 & 0.49 & 1.33 & 0.69 & 0.40 & 0.26 & 0.48 & 0.14 & 0.23 \\
\hline
\end{tabular}}

39 12 Dip Stick Rain Gage Reading: 0.60 inches of precipitation from 09/03/00 to 10/02/00. 


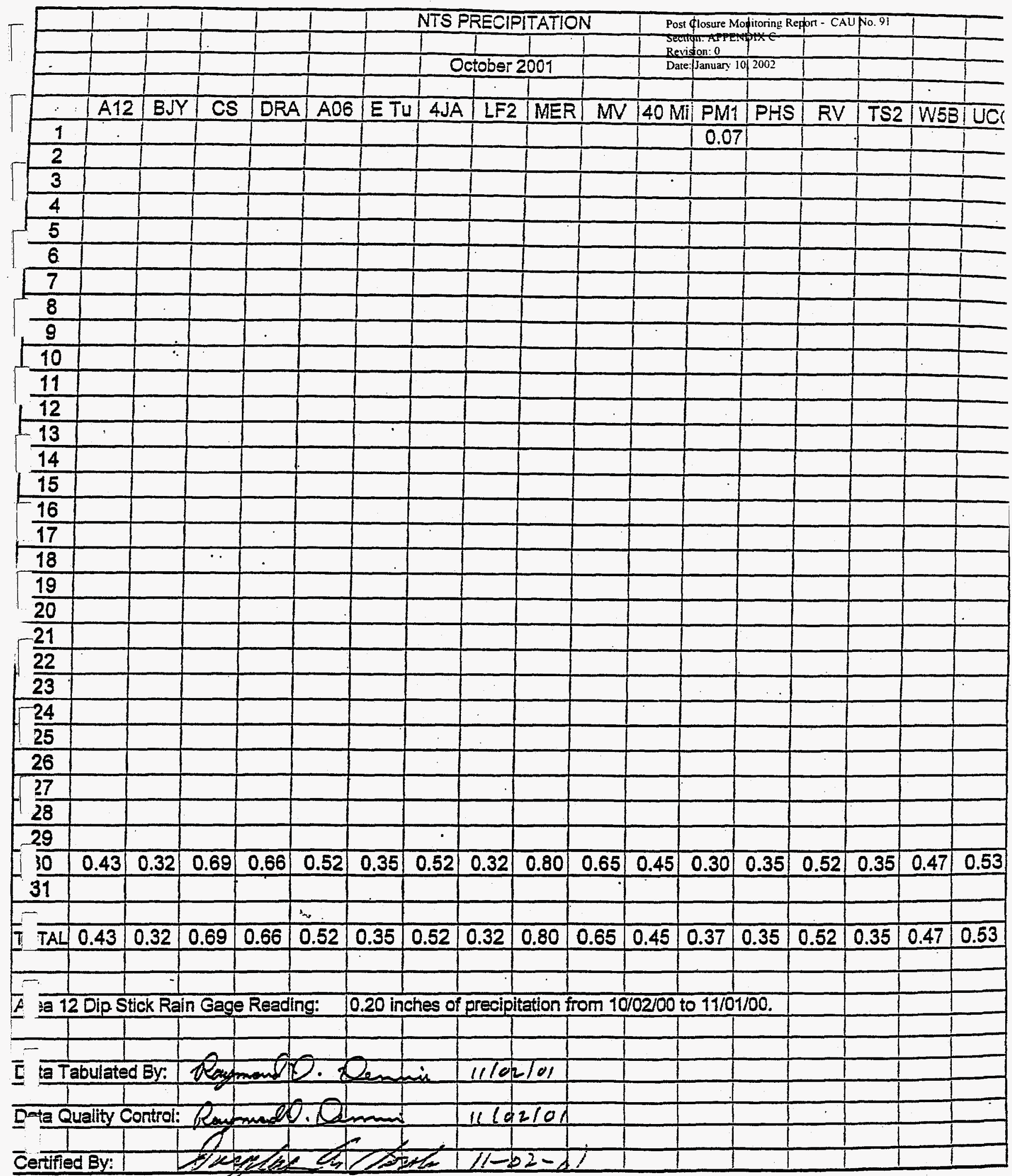


Post Closure Monitoring Report - CAU No. 91

\title{
THIS PAGE INTENTIONALLY LEFT BLANK
}

\author{
C-14
}


Post Closure Monitoring Report - CAU No. 91 Section: DISTRIBUTION

Revision: 0

Date: January 10, 2002

\section{DISTRIBUTION LIST}


Post Closure Monitoring Report - CAU No. 91 Section: DISTRIBUTION

Revision: 0

Date: January 10, 2002

\section{THIS PAGE INTENTIONALLY LEFT BLANK}




\section{DISTRIBUTION LIST}

*Provide copy of initial distribution of Revision 0 ; remainder of list gets Revision 0 if approved without changes. The entire list receives Revision 1, if issued.

\section{Nevada Department of Environmental Protection}

Paul Liebendorfer

Bureau of Federal Facilities

Division of Environmental Protection

333 W. Nye Lane, Room 138

Carson City, NV 89706-0866

Supervisor, Las Vegas Office

1 (Controlled)*

Bureau of Federal Facilities

Division of Environmental Protection

555 E. Washington, Suite 4300

Las Vegas, NV 89010-1043

\section{U.S. Department of Energy}

Janet Appenzeller-Wing

1 (Uncontrolled)*

Project Manager

Environmental Restoration Division

U.S. Department of Energy

National Nuclear Security Administration

Nevada Operations Office

P.O. Box $98518 \mathrm{M} / \mathrm{S} 505$

Las Vegas, NV 89193-8518

Sabine Curtis

1 (Uncontrolled)*

Environmental Restoration Division

U.S. Department of Energy

National Nuclear Security Administration

Nevada Operations Office

P.O. Box $98518 \mathrm{M} / \mathrm{S} 505$

Las Vegas, NV 89193-8518 


\section{DISTRIBUTION LIST (continued)}

\section{U.S. Department of Energy (continued)}

Sabrina Lawrence

Environmental Restoration Division

U.S. Department of Energy

National Nuclear Security Administration

Nevada Operations Office

P.O. Box $98518 \mathrm{M} / \mathrm{S} 505$

Las Vegas, NV 89193-8518

U.S. Department of Energy

1 (Electronic copy)

Office of Scientific and Technical Information

1 (Controlled)*

P.O. Box 62

Oak Ridge, TN 37831-0062

U.S. Department of Energy

National Nuclear Security Administration

1 (Controlled) \&

Nevada Operations Office

1 (Uncontrolled)

Public Reading Facility

P.O. Box $98521 \mathrm{M} / \mathrm{S}$ NLV040

Las Vegas, NV 89193-8521

U.S. Department of Energy

National Nuclear Security Administration

1 (Uncontrolled)

Nevada Operations Office

Technical Information Resource Center

P.O. Box $98521 \mathrm{M} / \mathrm{S} 505$

Las Vegas, NV 89193-8521

\section{Bechtel Nevada}

Correspondence Control

1 (Uncontrolled)*

Bechtel Nevada

P.O. Box $98521 \mathrm{M} / \mathrm{S}$ NLV008

Las Vegas, NV 89193-8521

D-2 


\section{DISTRIBUTION LIST (continued)}

\section{Bechtel Nevada (continued)}

Dudley Emer

1 (Uncontrolled)*

Bechtel Nevada

P.O. Box $98521 \mathrm{M} / \mathrm{S}$ NTS306

Las Vegas, NV 89193-8521

Environmental Management Library

1 (Uncontrolled)*

Bechtel Nevada

P.O. Box 98521 N/S NLV080

Las Vegas, NV 89193-8521

Ann Heidema

1 (Uncontrolled)

Bechtel Nevada

P.O. Box $98521 \mathrm{M} / \mathrm{S}$ NLV022

Las Vegas, NV 89193-8521

Wayne Johnson

1 (Uncontrolled)*

Bechtel Nevada

P.O. Box $98521 \mathrm{M} / \mathrm{S}$ NTS306

Las Vegas, NV 89193-8521

Steve Nacht

1 (Uncontrolled)*

Bechtel Nevada

P.O. Box $98521 \mathrm{M} / \mathrm{S}$ NTS306

Las Vegas, NV 89193-8521

Jeffrey Smith

1 (Uncontrolled)*

Bechtel Nevada

P.O. Box $98521 \mathrm{M} / \mathrm{S}$ NTS306

Las Vegas, NV 89193-8521

Daniel Tobiason

1 (Uncontrolled)*

Bechtel Nevada

P.O. Box $98521 \mathrm{M} / \mathrm{S}$ NTS306

Las Vegas, NV 89193-8521 


\section{DISTRIBUTION LIST (continued)}

\section{IT Corporation}

Raymond Kidman

1 (Controlled)

IT Corporation

P.O. Box $93838 \mathrm{M} / \mathrm{S} 439$

Las Vegas, NV 89193-8521

Garry Romano

1 (Controlled)

IT FFACO Support Office

IT Corporation

P.O. Box 93838 M/S 439

Las Vegas, NV 89193-8521

\section{State of Nevada}

Manager, Northern Nevada

FFACO Public Reading Facility

1 (Controlled) \&

Nevada State Library and Archives Federal Publications

1 (Uncontrolled)

100 North Stewart Street

Carson City, NV 89701-4285 